\title{
SANCTI CIRICI DE COLERA / SANT QUIRZE DE COLERA (ALT EMPORDÀ, GIRONA). ESTUDIO PRELIMINAR DEL CONJUNTO MONÁSTICO, SIGLOS VIII AL XVI
}

\section{GISELA RIPOLL, EDUARDO CARRERO, DANIEL RICO, NÚRIA MOLIST, ÀNGELA G. CENTELLES, JOSEP BENSENY, JOAN TUSET, JELENA BEHAIM, JOSÉ MARTÍNEZ, FRANCESC TUSET}

\author{
UDC: $726.71(460.23) " 07 / 15 "$ \\ 902.3 \\ Original scientific paper \\ Manuscript received: 03. 03. 2017. \\ Revised manuscript accepted: 28. 04. 2017. \\ DOI: 10.1484/J.HAM.5.113750
}

\author{
G. Ripoll* \\ E. Carrero**, D. Rico** \\ N. Molist ${ }^{* * *}$, À. G. Centelles* \\ J. Benseny*, J. Tuset* \\ J. Behaim**, J. Martínez ${ }^{* * * *}$
} F. Tuset*

Sancti Cirici de Colera / Sant Quirze de Colera is a Benedictine monastic foundation on the southern face of the eastern Pyrenees. The various structures that have survived as well as the documentary sources provide a wide chronological range of the 8th to 16th centuries, when the monastic community moved to another location. In the 19th century the site became private property and in the 1990s the first efforts at restoration and archaeological excavation began. Our programme of new research into this very special complex began two years ago with a multi-disciplinary approach focusing on the entire complex and all its aspects: the analysis of written sources and preserved remains in order to understand and outline its principal phases of development, not only structural but also functional and liturgical, using all the most modern instruments and technologies of the various disciplines concerned. In order to achieve the maximum results, our analyses have followed a number of different techniques which include a topographic map, photogrammetry, plans and 3D modelling-reconstruction, as well as chrono-stratigraphical, architectural and liturgical analyses, that have allowed us to define the various historical phases in which this monastic site was founded, developed and finally abandoned. We present here some of the first results which, although preliminary, serve to illustrate the work being undertaken and the consequent reinterpretation of the abbatial church now possible.

Key words: Benedictine monastery, Early Middle Ages, Catalonia, architecture, liturgy, photogrammetry, stratigraphy.

\section{PRELIMINAR}

El estudio emprendido en Sant Quirze de Colera se enmarca en un proyecto de investigación que lleva por título Ecclesiae, coemeteria et loci (saec. VIII-XI). Sancti Cirici de Colera, Sidilianum, Olerdola / Esglésies, cementiris i hàbitats (segles VIII al XI). Sant Quirze de Colera, Sidillà, Olèrdola $(E C L O C)^{1}$. El objetivo que se persigue con este proyecto es comprender la dinámica de la transformación del paisaje monástico, rural y urbano entre los siglos VII-VIII y XII, a partir del trinomio secuencial, evolutivo y complejo de iglesia, hábitat y necrópolis, integrando la excavación, el estudio arquitectónico y textual y la topografía, junto con todas las posibilidades que ofrecen las nuevas tecnologías y las técnicas analíticas. Para ello seleccionamos tres yacimientos aparentemente distintos y con una realidad arquitectónicomonumental propia.
Olerdola / Olèrdola (en el Penedès, al sur de Barcelona), es una civitas medieval con gran desarrollo urbano organizado en dos grandes barrios, uno intra muros y otro fora muros. Los dos con iglesia, necrópolis y hábitat, funcionando contemporáneamente desde los siglos VIII / IX hasta el XII. Nuestros trabajos se centran en el barrio fuera de la muralla, conocido como Pla dels Albats que ocupa una extensión de cerca 6 hectáreas en el que no se ha realizado hasta ahora ningún proyecto científico. El otro yacimiento es Sidilianum / Sidillà (al nordeste de Girona), un conjunto profundamente abandonado y maltratado. Se trata de una aglomeración de carácter rural de pequeñas dimensiones, asentada sobre una villa romana, con una iglesia parroquial, un poblado y un edificio funerario, con sepulturas en todo el entorno. Siempre considerada una iglesia del siglo X, las intervenciones nos han permitido datar el edificio a inicios del siglo VIII y localizar los elementos del primer santuario: altar y caja de reliquias. Las

\footnotetext{
*. ERAAUB/Universitat de Barcelona, Facultat d'Història, Secció de Prehistòria i Arqueologia - C/ Montalegre, 6, E-o8oo1 Barcelona. giselaripoll@ub.edu, angelagonzalez.ub@gmail.com, josep@benseny.cat, joantusetestany@gmail.com, ftuset@ub.edu

**. Universitat Autònoma de Barcelona, Departament d'Art i Musicologia, Edifici B, Campus de la UAB, E-o8193 Bellaterra (Cerdanyola del Vallés) Barcelona. Eduardo.Carrero@uab.cat, daniel.rico@uab.es, jelenabehaim@gmail.com

***. MAC/Museu d'Arqueologia de Catalunya - Passeig de Santa Madrona 39-41, E-o8oz8 Barcelona. nmolist@gencat.cat

****. LFA/ETSA/Laboratorio de Fotogrametría Arquitectónica de la Escuela de Arquitectura de Valladolid - Avda. de Salamanca, 18, E-47014 Salamanca jmrubio@ega.uva.es
}

${ }^{1}$ Este texto se inscribe dentro de los trabajos realizados por el ECLOC proyecto que se ejecuta en el marco de la convocatoria Projectes quadriennals de recerca en matèria d'arqueologia i paleontologia per al període 2014-2017, Direcció General de Patrimoni Cultural, Generalitat de Catalunya (núm. exp.: 2014/100480) y del ERAAUB / Equip de Recerca Arqueològica i Arqueomètrica, Universitat de Barcelona (Grup de Recerca Consolidat 2014SGRo845, Comissionat per a Universitats i Recerca del DIUE, Generalitat de Catalunya). Como es lógico el proyecto ECLOC y los conjuntos estudiados forman parte del CARE-Hispania. En la parte técnica correspondiente a los trabajos del LFA de Valladolid han participado los investigadores arquitectos D. Marcos González y L.A. García García, los directores del LFA, J. San José Alonso y J.J. Fernández Martín, han supervisado el trabajo. Agradecemos al Ajuntament de Rabós d'Empordà, especialmente a su alcaldesa Sra. D. Montiel, las facilidades que siempre nos ha dado para desarrollar los trabajos en el monasterio y al Servei d'Arqueologia i Paleontologia de la Generalitat de Catalunya, en las personas de M. Mascort y M. Mataró, por su constante ayuda en la localización de los informes y memorias. Somos también deudores por su apoyo y sugerencias a M. Miquel, de la l'Agència Catalana del Patrimoni Cultural, al Sr. J. Badia, al arquitecto J. Falgueras, así como al Dr. X. Barral y al Dr. R. Julià. Una breve presentación del ECLOC, pero también del CARE-Hispania y de los trabajos del ERAAUB en: M.A. CAU, R.M. ALBERT, J.M. GURT, V. MARTÍNEZ, C. MAS FLORIT, A. PECCI, P. REYNOLDS, G. RIPOLL, E. TSANTINI y F. TUSET, "El Equip de Recerca Arqueològica i Arqueomètrica de la Universitat de Barcelona (ERAAUB) (1992-2015)", Pyrenae, Número Especial 5oè aniversari (2015), 181-244 (pp. 209-216). 


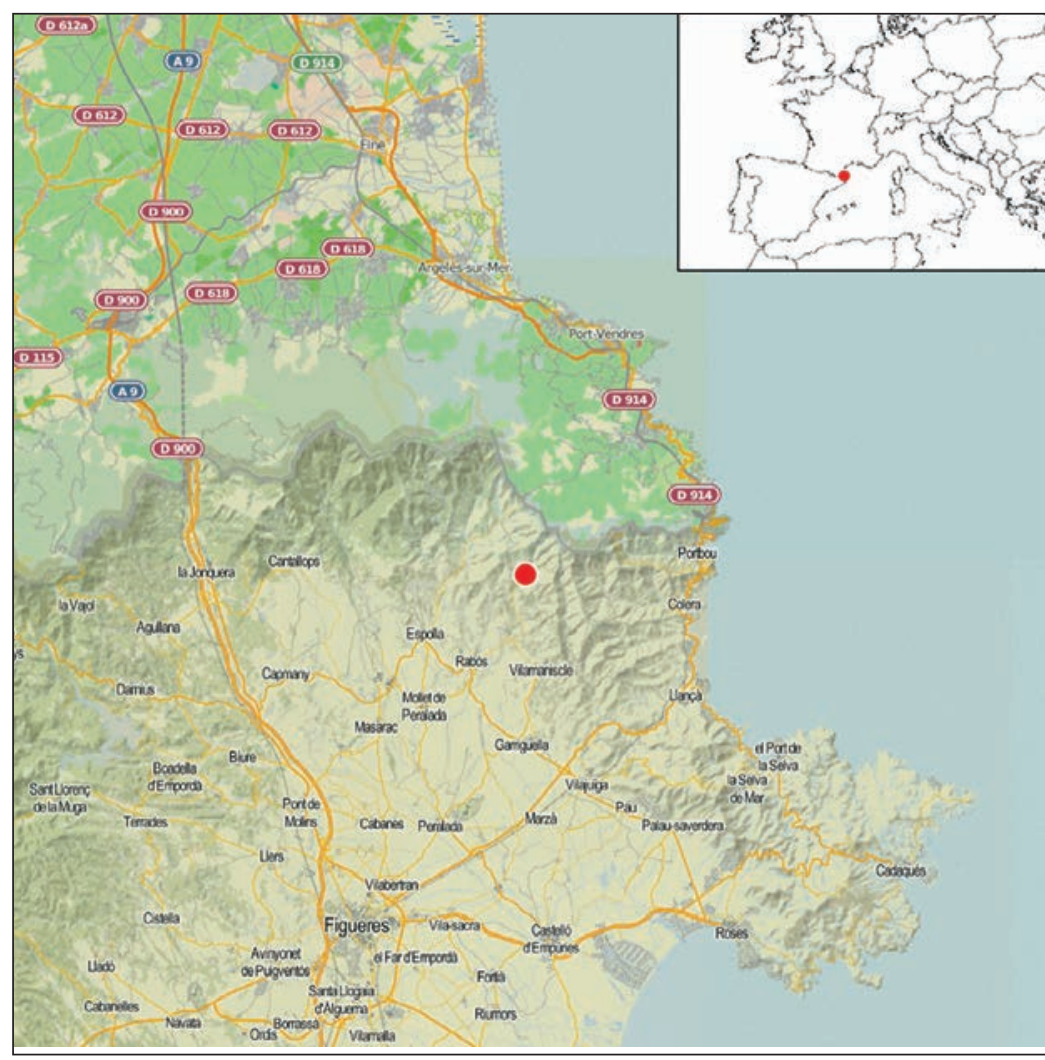

Fig. 1. Mapa de localización del conjunto monumental de Sant Quirze de Colera (Rabós d'Empordà, Parque Natural de l'Albera, Alt Empordà) (ECLOC). excavaciones de las estructuras del poblado que ocupan, por el momento, más de $600 \mathrm{~m}^{2}$ atestiguan una necrópolis anterior, una ocupación intensa en los siglos Xy XI y un abandono progresivo a partir de mediados del siglo XI cuando todo el conjunto queda cubierto por gran una duna provocada por los desvíos que se operan en el río Ter, a escasos metros del yacimiento.

Por último, el otro yacimiento integrado en el marco del proyecto ECLOC es el monasterio de Sancti Cirici de Colera / Sant Quirze de Colera situado en un paraje de gran belleza natural, al pie del macizo de la Albera, punto de paso natural para cruzar el Pirineo, a menos de $10 \mathrm{~km}$ de la costa a vuelo de pájaro, y a la 'sombra' del conocidoy majestuoso Sant Pere de Rodes (fig. 1). Se trata de un conjunto de grandes dimensiones, dotado de una iglesia parroquial y una monástica además de todas las dependencias del monasterio y una necrópolis, con una dilatada cronología, desde el siglo VIII hasta el siglo XVI, momento en que la comunidad monástica se traslada (figs. 2 y 3). En el siglo XIX y hasta los años 1990 estuvo en manos privadas provocando, si cabe, una gran degradación de todas las estructuras. Cuando en 1994 fue vendido al Ayuntamiento de Rabós d'Empordà se iniciaron las primeras consolidaciones, restauraciones e intervenciones arqueológicas que pusieron al descubierto una extensa necrópolis previa a la construcción eclesiástica con tumbas localizadas tanto en el interior de la iglesia como en su fachada, en el claustro y su entorno.

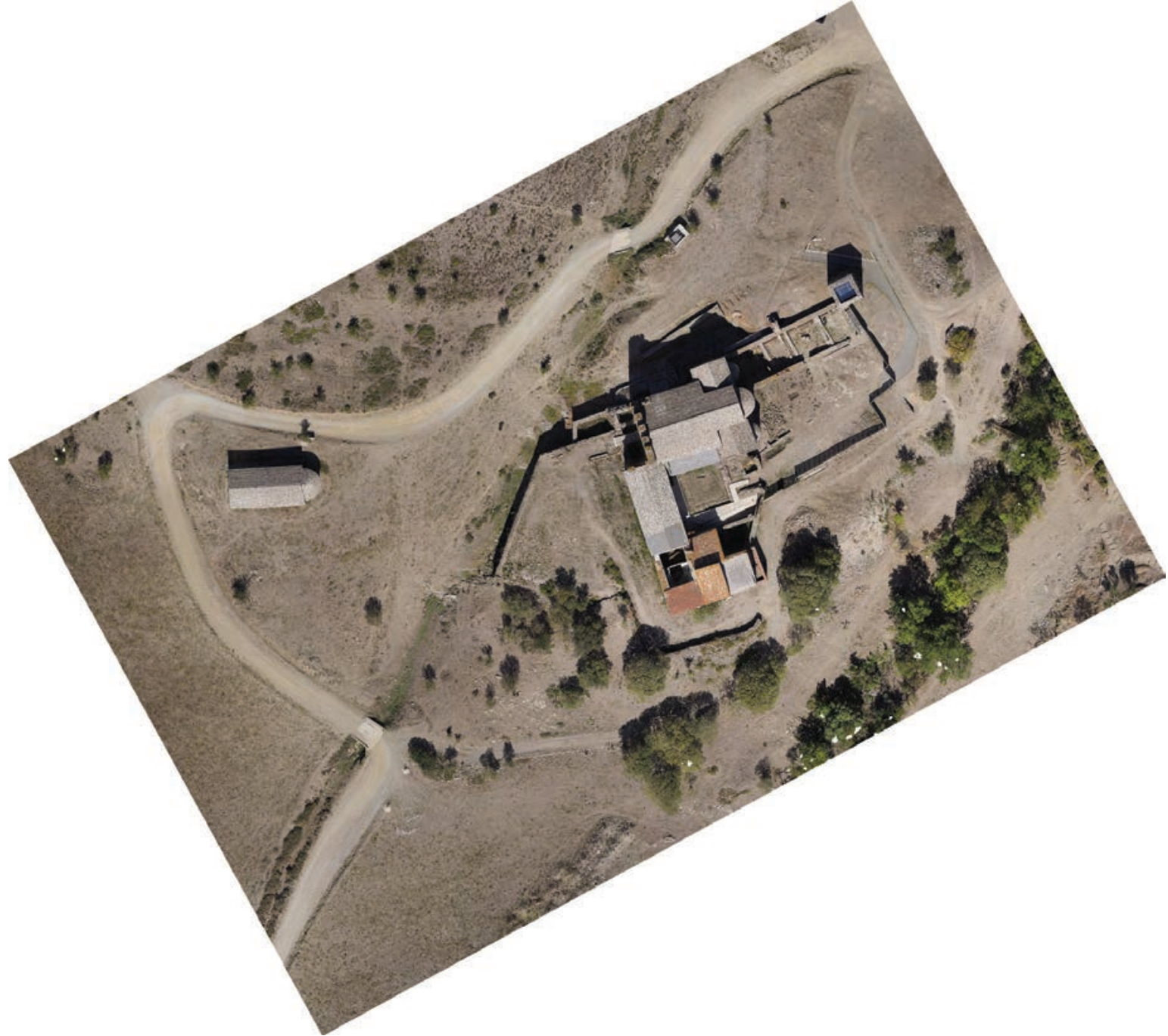

Fig. 2. Ortofotografía con las estructuras del complejo monástico de Sant Quirze y al oeste la iglesia parroquial de Santa María (ECLOC/LFA). 


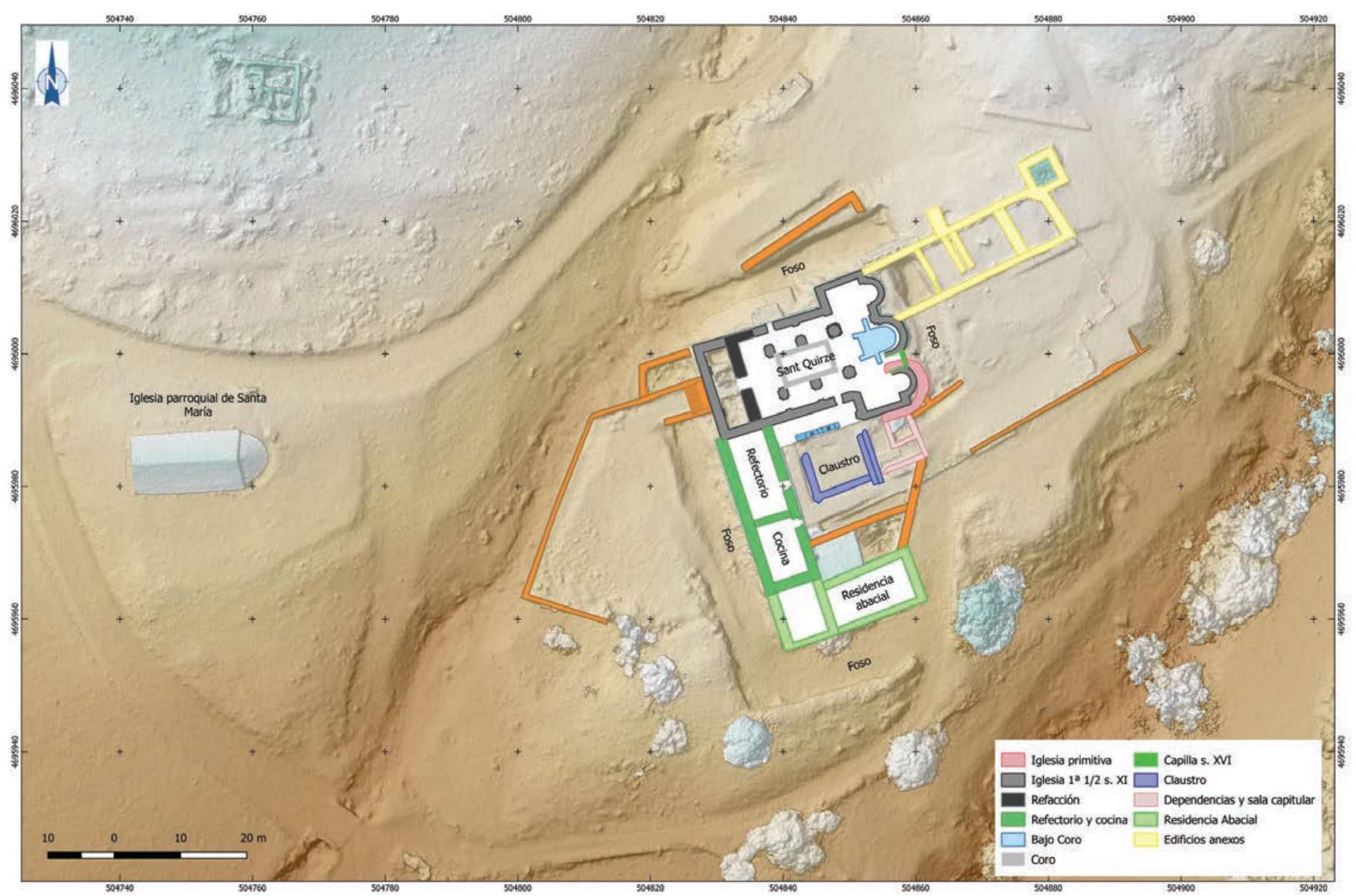

Fig. 3. Planta general del conjunto de estructuras del complejo monástico de Sant Quirze de Colera (ECLOCIJ. Benseny, F. Tuset y G. Ripoll).

No obstantey a pesar de la importancia que tuvo en época medieval y su majestuosa monumentalidad, el conjunto ha suscitado muy poco interés entre los historiadores y por parte de la administración y adolece de una gran fragilidad en el sentido patrimonial. Todos estos factores han hecho que dentro del proyecto ECLOC emprendamos un estudio integral con un equipo interdisciplinar utilizando todos los medios a disposición. Nuestro objetivo es el análisis de las fuentes y de las estructuras conservadas para comprender las fases y transformaciones tanto constructivas como funcionales y litúrgicas, utilizando todos los instrumentos y nuevas tecnologías propias de las diversas disciplinas. Para la correcta ejecución de este análisis estamos trabajando en diferentes líneas. Desde la elaboración de una topografía, una fotogrametría, una planimetría y un modelo 3D, hasta el análisis crono-estratigráfico, arquitectónico y litúrgico, en definitiva, los parámetros históricos en los que se funda, se desarrolla y, al final, se abandona, el conjunto monástico. Presentamos aquí unos primeros resultados que, aunque provisionales, muestran el trabajo en curso y las consecuentes reinterpretaciones de la iglesia abacial.

\section{LA LOCALIZACIÓN DE SANT QUIRZE DE COLERA}

El conjunto monástico de Sant Quirze de Colera se sitúa en el macizo de la Albera, en el extremo oriental de los Pirineos y dentro de los límites del Paraje Natural de Interés Nacional de l'Albera (Lat $42^{\circ} 24^{\prime} 58.32^{\prime \prime} \mathrm{N}$ - Long $3^{\circ} 3^{\prime} 32^{\prime \prime} \mathrm{E}$ / X: 504996.35 - Y: 4696154.24). Pertenece al municipio de Rabós d'Empordà, en la comarca de l'Alt Empordà (Girona).
Está situado en la ladera este del Puig Abreu, a 176 m.s.n.m., en un paraje de vegetación mediterránea donde predominan los matorrales, brezos y retamas, con poca presencia de alcornoques y pinos, al contrario de lo que sucede en el sector occidental, caracterizado por una vegetación más húmeda. Desde que a finales del siglo XIX todo el territorio fuera afectado por la plaga de la filoxera, la mayoría de campos de vides que rodean el monasterio han sido transformados en prados y pastos.

Sant Quirze de Colera se emplaza en el fondo de un pequeño valle al que da nombre, el valle de la riera de Sant Quirze o de la Reguerada. Geológicamente, el valle es una llanura de inundación ordinaria del Holoceno reciente, mientras que las montañas que la rodean son formaciones del período Cambro-Ordoviciano. El estudio de los materiales constructivos del conjunto monástico evidencia el uso de rocas ígneas o volcánicas como el granito y la traquita y de origen metamórfico como el mármol, el cuarzo, la filita, el esquisto y la pizarra, relacionados con las formaciones rocosas de este sector pirenaico y con los conos volcánicos que están en constante erosión en la llanura litoral que forma el río Fluvià. Se trata por tanto de una construcción realizada prácticamente toda con materias primas procedentes del entorno inmediato.

La hondonada de Sant Quirze viene marcada por el camino que da acceso al Coll de Banyuls (356 m.s.n.m.), el paso natural que cruza los Pirineos y constituye una vía de comunicación fundamental entre la Península y Europa. Desde el siglo II a.C., un ramal interior de la via Domitia pasaba por el Coll de Banyuls, evidenciando la importancia 
de este paso ya en el período romano ${ }^{2}$. En época carolingia forma parte del mítico "Camino de Carlomagno"s, citado en leyendas relativas a la conquista franca y considerado como la ruta de expansión de la cultura carolingia en relación con la línea de los primeros monasterios benedictinos y las iglesias de los siglos X y XI.

Sant Quirze deriva de Sancti Quirico o Cirici, un nombre mencionado en todas las fuentes, desde el primer texto conocido -el del año 844- hasta los más tardíos. Interesa resaltar que en el texto del 844 (cf. infra) se cita el topónimo de Leocarcari o Leucarcari refiriéndose a las montañas, valles y tierras que rodean y/o pertenecen al monasterio. El topónimo está compuesto por el prefijo del adjetivo griego $\lambda \varepsilon v \kappa o ́ \varsigma$, que significa albo, blanco, y el sufijo -carcari, derivado del latín carcer, prisión. Es posible que el topónimo Albera encuentre su origen en el latín albus como transliteración de $\lambda \varepsilon \cup \kappa o ́$, y el sufijo -aria, en el sentido de empleo o de lugar, o bien que derive, no sin dudas, directamente de albarius, que significa estuco, siempre de color muy claro ${ }^{4}$.

A inicios de la Edad Media el paisaje era completamente diferente. Importantes bosques explotados y espacios dedicados a la ganadería y a la agricultura con presencia de hábitat disperso dependiente del monasterio. Un ejemplo se encuentra en las estructuras localizadas en el nordeste prácticamente sobre el curso de agua del Rec de la Perdiu, a escasos 250 metros de distancia del conjunto, el llamado mas dels Felius, donde las excavaciones pusieron de relieve un hábitat fechable en el siglo XI y que debió estar en uso -al menos- hasta finales del siglo XVI5.

\section{ANTECEDENTES ARQUEOLÓGICOS E INTERVENCIONES DE CONSOLIDACIÓN, RESTAURACIÓN Y ADECUACIÓN}

Las primeras intervenciones arqueológicas de las que tenemos noticia se remontan a la década de 1970, aunque de ellas no existe prácticamente documentación. También se sabe que en 1984 se vaciaron varios rellenos de tierra en el claustro, en la llamada "casa del abad" y en la fortificación contigua, donde a su vez se realizaron tareas de consolidación ${ }^{6}$.

En 1994 el monasterio pasó de manos privadas a ser propiedad del Ayuntamiento de Rabós d'Empordà, lo que supuso impulsar un proyecto de excavación, restauración y consolidación. Desde el Servei de Patrimoni Arquitectònic de la Generalitat de Catalunya se encargó al arquitecto J. Falgueras que planificara la revalorización del conjunto. En el marco de dicho proyecto, se encomendaron una serie de informes con el objetivo de evaluar el estado de conservación arquitectónico, plantear intervenciones futuras y proponer una musealización ${ }^{7}$. De este modo, y en función de las fases previstas para la restauración, se iniciaron las primeras excavaciones arqueológicas. En 1997 se intervino en el área del claustro, ocupado por una vasta necrópolis, y en la zona exterior de la cabecera de la iglesia, documentándose, al este de los ábsides, un foso recortado en la roca con orientación norte-sur ${ }^{8}$. Sin embargo, a causa del mal estado de conservación de la estructura, en el año 2000, el Servei de Patrimoni Arquitectònic del Departament de Cultura solicitó a J. Falgueras un 'Plan Director'9, que debía ser el eje conductor de todas las intervenciones venideras en el conjunto del cenobio pero que no ha sido ejecutado en su totalidad.

El proyecto contó con una primera fase de intervenciones donde los trabajos arqueológicos fueron desarrollados en función de las obras de consolidación y restauración (20002003). Así se realizó el control arqueológico de las obras de las cubiertas de la iglesia, pudiendo documentar al menos dos fases diferenciadas: una primera de cronología indeterminada y una reforma posterior fechada mediante hallazgos cerámicos en el siglo XIV ${ }^{10}$. También se llevó a cabo el refuerzo y consolidación de los cimientos y la fachada del ángulo noroeste, uno de los puntos débiles y problemáticos de la estructura arquitectónica de la iglesia monástica. Durante las obras de apuntalado de la fábrica en dicho costado, se documentaron dos sepulturas excavadas en la roca y algunos niveles de derrumbe en un sondeo realizado en el exterior norte de la iglesia".

Entre 2002 y 2004 se excavó en el interior de la iglesia y en el refectorio, situado en el sudoeste de ésta. En la zona de la cabecera de la iglesia, frente al ábside mayory en pleno transepto, se identificaron una serie de estructuras construidas en piedra y forradas con mortero que fueron interpretadas como parte de una cripta de cronología anterior ${ }^{12}$. En esta misma intervención arqueológica se excavaron varias sepul-

${ }^{2}$ G. CASTELLVI, J.-P. COMPS, J. KOTARBA, A. PEZIN (dir.), Voies romaines du Rhône à l’Èbre : via Domitia et via Augusta, Documents d'Archéologie Française, 61 (Paris: Éditions de la Maison des Sciences de l'Homme, 1997). G. CASTELLVI, La via Domitia et ses embranchements (Canet de Roussillon: Éditions Trabucaire, 2011).

3 J. CLARÀ, "El camí de Carlemany a la Catalunya Vella", Butlletí Interior, Societat d'Onomàstica, 6o (1995), 301-306.

${ }^{4}$ S. PÉREZ, "Topónimos catalanes de origen griego", Sección de Estudios ibéricos "D. Fletcher Valls" Estudios de lenguas y epigrafía antiguas - ELEA, 9 (2009), 431-46o (pp. 444-445).

${ }^{5}$ Las excavaciones llevadas a cabo por la Universitat de Girona, bajo la dirección de Ll. Palahí y D. Vivó, fueron objeto de una noticia en la prensa, cf. D. CHICANO, "Excaven un mas medieval dependent de Sant Quirze", El Punt Avui, 20/07/2012.

${ }^{6}$ Excavaron en el monasterio Miquel Oliva i Prat (1973-1974) y Pere Freixes (1975-1976), cf. D. CODINA, "Sant Quirze de Colera. Un jaciment arqueològic excepcional", Annals de l'Institut d'Estudis Empordanesos, 43 (2012), 39-63 (pp. 40-41).

${ }_{7}$ Se realizaron estudios del estado de las pinturas murales por M. Marqués y C. Payàs, del comportamiento geotécnico del terreno por Losan y del análisis de los materiales constructivos, sus patologías y sugerencias de conservación por M. Vendrell. Toda esta documentación es consultable en el Servei de Arqueologia de la Generalitat de Catalunya.

${ }^{8}$ D. CODINA, op.cit. (n. 6), p. 41.

9 J. FALGUERAS I FONT, “El monestir de Sant Quirze de Colera a Rabós, 30 anys de rehabilitació urbana (1978-2008)”, in Departament de Política Territorial i Obres Públiques, Generalitat de Catalunya (2010), 155-163.

${ }^{10}$ D. CODINA y A. VARGAS, “El desmantellament de la teulada de l'església del monestir de Sant Quirze de Colera”, VI Jornades d'Arqueologia de les Comarques Gironines, Sant Joan de les Abadesses (2002), 479-480.

${ }^{n}$ M. TEIXIDOR, "Seguiment arqueològic a la banda nord de l'edifici monacal de Sant Quirze de Colera (Rabós d'Empordà, Alt Empordà)", VI Jornades d'Arqueologia de les Comarques Gironines, Sant Joan de les Abadesses (2002), 387-388.

${ }^{12}$ D. CODINA y C. MONTALBÁN, "Resultats de la intervenció arqueològica realitzada a l'interior de l'església del monestir de Sant Quirze de Colera (Rabós, Alt Empordà)", VII Jornades d'Arqueologia de les comarques de Girona, La Bisbal d'Empordà (2004), 473-476. 


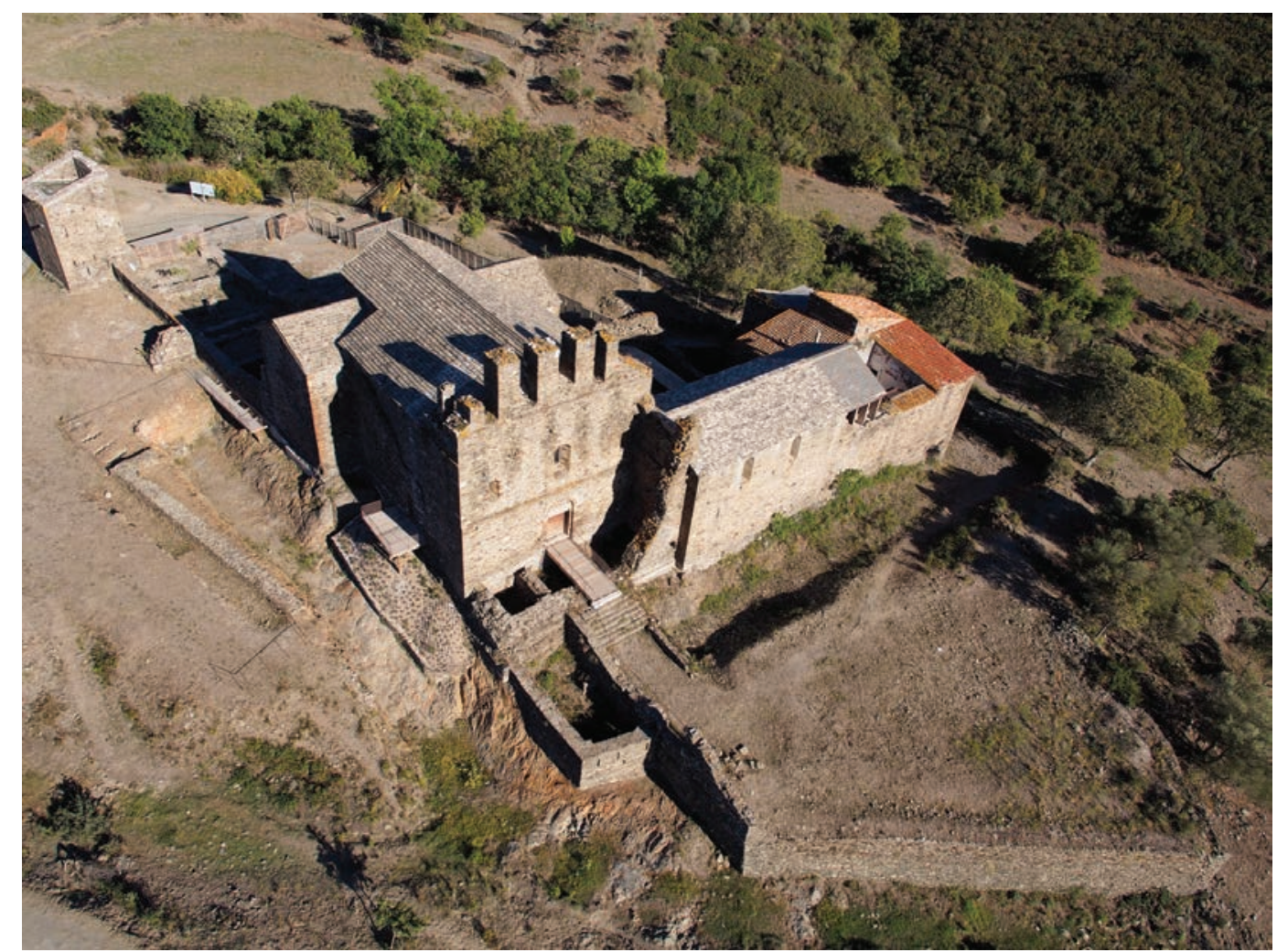

Fig. 4. Conjunto de estructuras que componen el complejo monástico de Sant Quirze de Colera (ECLOC/LFA).

turas antropomorfas recortadas en la roca, distribuidas en las tres naves de la iglesia y en el transepto que se suman a las localizadas anteriormente en el ábside sur. Dos de ellas fueron objeto de dataciones de ${ }^{14} \mathrm{C}$, aportando una cronología de segunda mitad del siglo VIII'3, lo que atestigua una ocupación del lugar muy anterior a la primera fuente escrita de la que se tiene noticia. También se excavó un alto número de tumbas en la zona ocupada por el refectorio.

A continuación, entre el 2004 y 2007 se acometió una segunda fase de adecuación, destinada a mejorar la circulación y la visita. Se reforzaron los dos pilares del noroeste de la nave y se iniciaron las obras de acondicionamiento del área de la cabecera, el refectorio y la "casa del abad", que incluían la restauración y consolidaron de las pinturas murales conservadas y de las estructuras de la supuesta cripta y del refectorio ${ }^{14}$.

La tercera fase del proyecto (2008-2009) se centró en la adecuación de la cubierta y el interior del refectorio, así como el acondicionamiento de las galerías del claustro para la circulación ${ }^{15}$. La datación por ${ }^{14} \mathrm{C}$ de un individuo del claustro proporcionó una cronología de alrededor del año 900 d.C.. ${ }^{16}$.

Entre 2011 y 2013 se acondicionó la zona norte de la fortificación y la iglesia para mejorar el recorrido y la visita mediante la instalación de pasarelas y plataformas.

Así mismo, la iglesia de Santa María, la parroquial, situada a poco más de 50 metros al oeste del monasterio, ha sido objeto en los últimos años de diferentes intervenciones dada la degradación de la estructura arquitectónica. Las

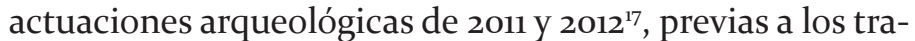
bajos de restauración, revelaron la presencia de un espacio delimitado por dos muros y pavimentado con mortero en la zona oeste del interior del edificio. Se excavó la cimentación de la iglesia, una banqueta adosada al muro norte y al ábside y varios agujeros de estacas. Cabe destacar la presencia de diversas sepulturas antropomorfas excavadas en la roca, algunas de las cuales son anteriores a la construcción de la iglesia, evidenciando un uso funerario de la zona previo ya a la construcción del edificio de culto. En los trabajos de restauración posteriores se reconstruyó la cubierta de bóveda preexistente y se acondicionó el interior con plataformas, paneles informativos y alumbrado para la visita de los restos arqueológicos previamente consolidados.

Todas estas circunstancias, y tal como se ha dicho al principio de estas páginas, han hecho que dentro del proyecto ECLOC enfoquemos el estudio integral del conjunto monástico desde una perspectiva interdisciplinar (fig. 4), empezando por una topografía, una fotogrametría, una planimetría y un modelo $3 \mathrm{D}$ que genera toda una documentación gráfica necesaria para el análisis crono-estratigráfico, arquitectónico y litúrgico, pero también textual, con el fin de establecer los parámetros históricos de Sant Quirze de Colera.

\section{TOPOGRAFÍA, FOTOGRAMETRÍA Y MODELIZACIÓN 3D}

De los trabajos de documentación geométrica del monasterio se ocupa el Laboratorio de Fotogrametría Arquitectóni-

\footnotetext{
${ }^{13}$ D. CODINA, op.cit. (n. 6), p. 46.

${ }^{14}$ M. MARQUÈS, "Intervención en pintura mural románica fragmentada, el uso de los revoques para el tratamiento de su imagen”, IV Congreso del GEIIC, Cáceres (2009), 267-276 (p. 275).

${ }^{15}$ J. FALGUERAS I FONT, op.cit. (n. 9), p. 57.

${ }^{16}$ Las dataciones fueron realizadas por Joan Salvador Mestres i Torres del Laboratorio de Datación por Radiocarbono de la Universitat de Barcelona.

${ }^{17}$ N. COLOMEDA, B. AGUSTÍ y A. DÍAZ, “Actuació arqueològica a l'església de Santa Maria de Sant Quirze de Colera (Rabós d'Empordà, Alt Empordà)", XI Jornades d'Arqueologia de les comarques de Girona, Girona (2012), 381-384.
} 


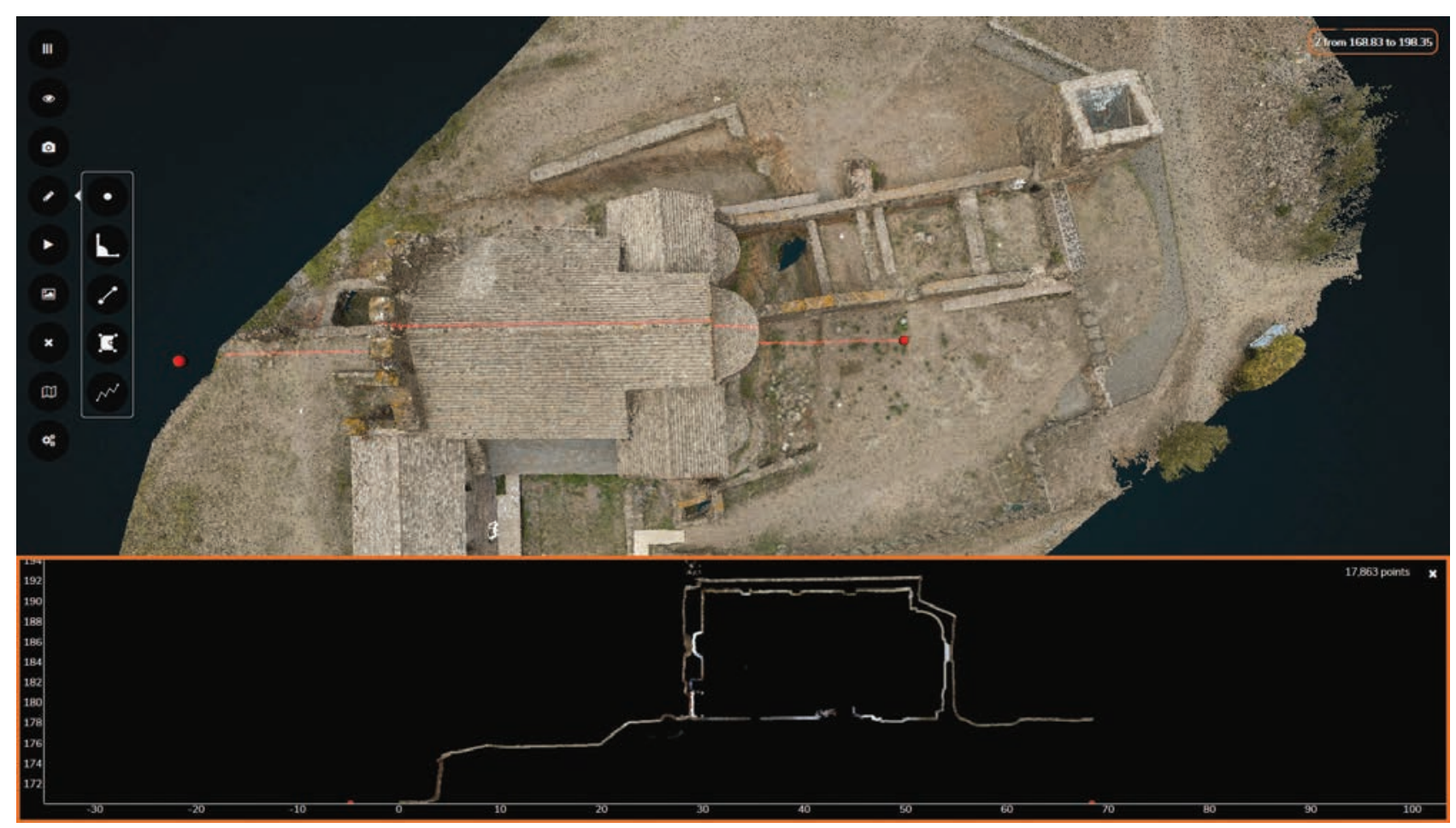

Fig. 5. Explotación de la nube de puntos por secciones (ECLOC/LFA).

ca de la Escuela de Arquitectura de Valladolid. El objetivo es proporcionar las bases gráficas del análisis de las diferentes partes que componen el conjunto monumental. Aplicando y combinando métodos topográficos y fotogramétricos el resultado es una nueva cartografía del emplazamiento y planimetrías ${ }^{18}$.

En el proceso de trabajo, además del equipo técnico humano, se han utilizado dos GPS -Trimble R8 y Trimble 5800-, un escáner láser Faro Focus 3D y una estación total Leica TRCmıoo, así como un considerable número de cámaras digitales, objetivos y cuatro drones para las operaciones aéreas. En el trabajo de campo se contó con varios ordenadores para procesar la información in situ y poder verificar diariamente su integridad y calidad.

El levantamiento, es decir la documentación, del edificio se ha basado en cuatro tecnologías complementarias: geodesia espacial, topografía clásica, topografía mediante escáner láser y fotogrametría.

La geodesia espacial, basada en receptores GPS, proporciona el marco de referencia global a los trabajos y su enlace al sistema de coordenadas oficial. Su aplicación permitió crear una red formada por una docena de bases topográficas fundamentales -señalizadas con marcas permanentes alrededor del monasterio- a cuya posición global se referirán todas las mediciones posteriores y los productos gráficos derivados de aquellas.

Esta red general se fue densificando con nuevas bases de medición según operaciones topográficas clásicas -por medio de una estación total- extendiendo la red de puntos de referencia hasta cubrir los diferentes espacios de interés en interiores y exteriores del conjunto de edificios. Desde las nuevas bases de estacionamiento se realizaron las mediciones de los puntos de control que servirían para dar una posición global a los datos capturados con las siguientes técnicas empleadas -láser y fotogrametría- consiguiendo así la completa unificación de datos y que todos los documentos se expresen en un mismo sistema de coordenadas para todo el registro.

Las técnicas de fotogrametría y láser se han combinado con el objetivo de incorporar sus pertinentes ventajas produciendo una base de datos a partir de ambos registros ${ }^{19}$. El primer resultado de la base de datos ha sido la generación de planimetrías precisas y detalladas del edificio, si bien se trata de una fuente de información inagotable que sirve para generar todo tipo de documentación gráfica en posteriores estudios dependiendo de las necesidades de los investigadores. La fotogrametría aporta un mayor grado de compleción dado que es capaz de alcanzar las partes o sectores de menor accesibilidad del propio edificio, como por ejemplo las cubiertas, y reúne una mayor cantidad de información cualitativa de fácil interpretación. El láser, por su parte, es capaz de producir una información con mejores cualidades en lo que respecta a la métrica que la fotogrametría, si bien es cierto que su explotación comporta ciertas dificultades.

\section{Trabajos topográficos con GNSS y Estación Total}

Como se ha citado anteriormente, la primera operación realizada en el monasterio sirvió para conformar una red básica de estaciones de referencia cuyas posiciones fueron determinadas por técnicas de geodesia espacial mediante receptores GNSS topográficos. Se ha utilizado el método

\footnotetext{
${ }^{18}$ El patrimonio monumental requiere unas técnicas de estudio específicas, véase el trabajo desarrollado por el LFA en: J. FINAT, F.J. DELGADO, R. MARTÍNEZ, J.J. FERNÁNDEZ, J.I. SAN JOSÉ y J. MARTÍNEZ, "Hacia una integración de los sistemas de documentación, información y gestión del patrimonio. Resultados y retos", in Documentación Gráfica del Patrimonio (Madrid: Ministerio de Cultura, 2011), pp. 164-177.

${ }^{19}$ Ejemplos de metodología implementados por el Laboratorio de Fotogrametría Arquitectónica en: J.I. SÁNCHEZ, J.I. SAN JOSÉ, J.J. FERNÁNDEZ, J. MARTÍNEZ y J. FINAT, "Integration of Hybrid Outdoor and Indoor Surveying. A Case Study in Spanish Renaissance Style Towers", Geoinformatics, 6, 2011, 132-139. Cuestiones esenciales de la práctica fotogramétrica en: F. REMONDINO, "Photogrammetry - Basic Theory", in F. REMONDINO y S. CAMPANA (eds.), $3 D$ Recording and Modelling in Archaeology and Cultural Heritage - Theory and Best Practices (Oxford: Archaeopress BAR Publication Series 2598, 2014 ), pp. 63-72.
} 


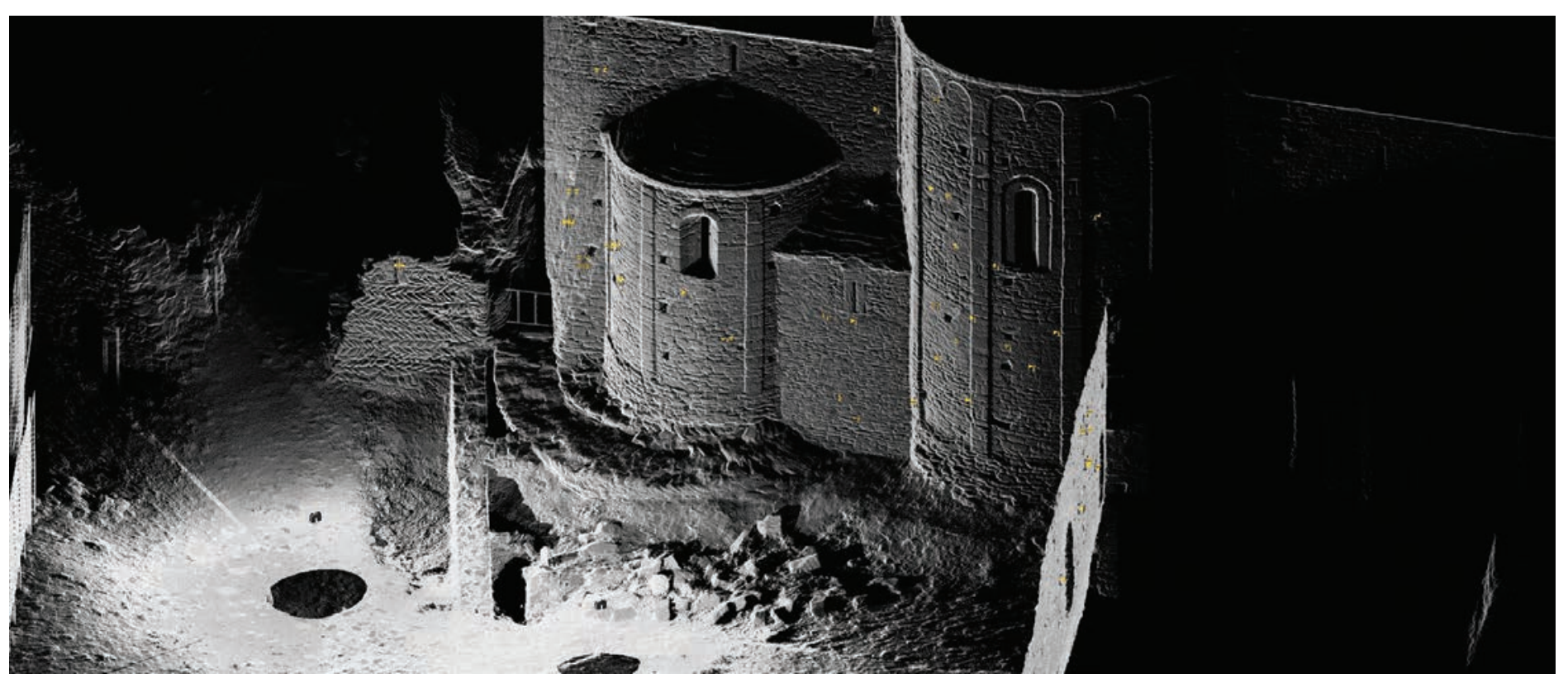

Fig. 6. Nube de puntos de láser escáner (ECLOC/LFA).

de "posicionamiento cinemático diferencial en tiempo real" (RTK) basado en la operación simultánea de dos receptores, uno fijo y otro móvil, que permiten situar una serie de puntos conformando una red de referencia.

El receptor estático transmite por radio en tiempo real al equipo móvil valores de corrección para las fluctuaciones aleatorias en la posición recibida de los satélites. Errores o variaciones que se puede asumir, afectan del mismo modo a ambos receptores en cada instante y, al saber que el receptor permanece estático, pueden ser determinados y enviados instantáneamente al receptor móvil. De este modo se consiguen obtener las coordenadas de esta red principal y expresarlas en el marco de referencia oficial definido por el datum ETRS89, UTM para el Huso $31 \mathrm{~N}$.

Con apoyo en esta red, se derivan otras bases de referencia para cuya medición se trabaja con la estación total. Se eligieron nuevos puntos de estacionamiento en el interior de la iglesia, el claustro y el refectorio, desde los cuales se realizó la medición directa de los puntos de control topográfico necesarios para georreferenciar los datos láser y de la fotogrametría.

Los puntos de control tienen, en el proceso fotogramétrico, varias funciones que en suma hacen posible establecer la relación entre el sistema de medición topográfica y los elementos de una escena fotográfica. Asimismo, estos puntos, sirven para enlazar los datos derivados del escaneo láser, vertebrando todo el levantamiento a partir de un sistema de referencia métrica común.

\section{Levantamiento láser y modelado fotogramétrico ${ }_{3} D$}

El levantamiento láser tridimensional utilizó para la captura de datos un escáner Faro Focus3D, caracterizado por ser de tamaño reducido, rápido y preciso. La 'nube de puntos' obtenida representa la topografía de las superficies (fig. 5). El total de estacionamientos para la documentación de todo el edificio ascendió a 120, cada uno de los cuales ha producido una nube que contiene entre 20 y 40 millones de puntos (fig. 6).

En paralelo a las labores de escaneo se han realizado capturas fotográficas para generar un modelo tridimensional completo por fotogrametría ${ }^{20}$. Todo el conjunto fue capturado, con más de 2500 imágenes, desde posiciones terrestres y aéreas mediante drones. Estas imágenes se utilizaron para obtener la geometría del conjunto y su entorno. El software emplea algoritmos automáticos structure from motion para la formación de nubes de puntos $3 \mathrm{D}$ con color real, ortofotos y modelos digitales de elevación.

El proceso fotogramétrico se divide en tres etapas: orientación de las imágenes, transformación de coordenadas al sistema topográfico y cálculo de correspondencia masiva para generar una nube de puntos $3 \mathrm{D}$ en color a partir de la cual se pueden derivar otros productos. La técnica permite determinar en un solo proceso las posiciones relativas de las cámaras en cada toma (orientación externa) y los parámetros de calibración que definen el comportamiento óptico de la misma, definiendo las distorsiones de la lente (orientación interna).

Se realizaron dos tipos de fotos aéreas con drones. Las de eje vertical alineadas sobre trayectorias rectilíneas y paralelas de altitud constante adecuadas para obtener una buena información de planta y las oblicuas y convergentes sobre las propias estructuras arquitectónicas de los edificios que contribuyen al modelado de los paramentos verticales.

Una vez calculadas las posiciones absolutas de los puntos de vista de las fotos, es posible hacer la reconstrucción $3 \mathrm{D}$ de la posición de cualquier punto que sea identificable en dos o más fotografías pudiéndose proceder a la correspondencia masiva de todos los píxeles de las fotos. Este principio básico permite la formación de nubes de puntos semejantes a las obtenidas por el láser, que posibilitan la construcción de geometrías basadas en mallas de las que se pueden ob-

\footnotetext{
${ }^{20}$ Para la modelización fotogramétrica 3D, aunque la bibliografía reciente es amplia, son de necesaria consulta: G.J. GRENZDÖRFFER, M. NAUMANN, F. NIEMEYER y A. FRANK, "Symbiosis of Uas Photogrammetry and Tls for Surveying and 3d Modeling of Cultural Heritage. A Case Study about the Cathedral of St. Nicholas in the City of Greifswald", The International Archives of the Photogrammetry, Remote Sensing and Spatial Information Sciences, XL-1/W4 (2015), 91-96. También: A. GUARNIERI, F. REMONDINO y A. VETTORE, "Digital photogrammetry and TLS data fusion applied to Cultural Heritage 3D modeling," in H.-G. MAAS y D. SCHNEIDER (eds.), Image Engineering and Vision Metrology, Proceedings of the ISPRS Commission V Symposium (Dresden: ISPRS Archives, XXXVI, Part 5, 2006).
} 
tener ortofotos y/o fotomosaicos de alta resolución.

Tal como se ha apuntado anteriormente, los datos obtenidos por el escaneo láser consiguen mejor calidad geométrica, sin embargo, la solución fotogramétrica ofrece la información del color que hace posible la interpretación simultánea de la forma y los aspectos cualitativos -material, color, aspecto, humedad, colonización biológica...- así como una mayor densidad y compleción.

El levantamiento fotogramétrico se completó con fotografías aéreas, consiguiendo un punto de vista elevado para la medición de las cubiertas y la planta de todo el conjunto y su entorno (fig. 7). En el trabajo desarrollado en Sant Quirze de Colera se utilizaron dos drones diseñados para la realización de grandes proyectos especializados en fotografía vertical.

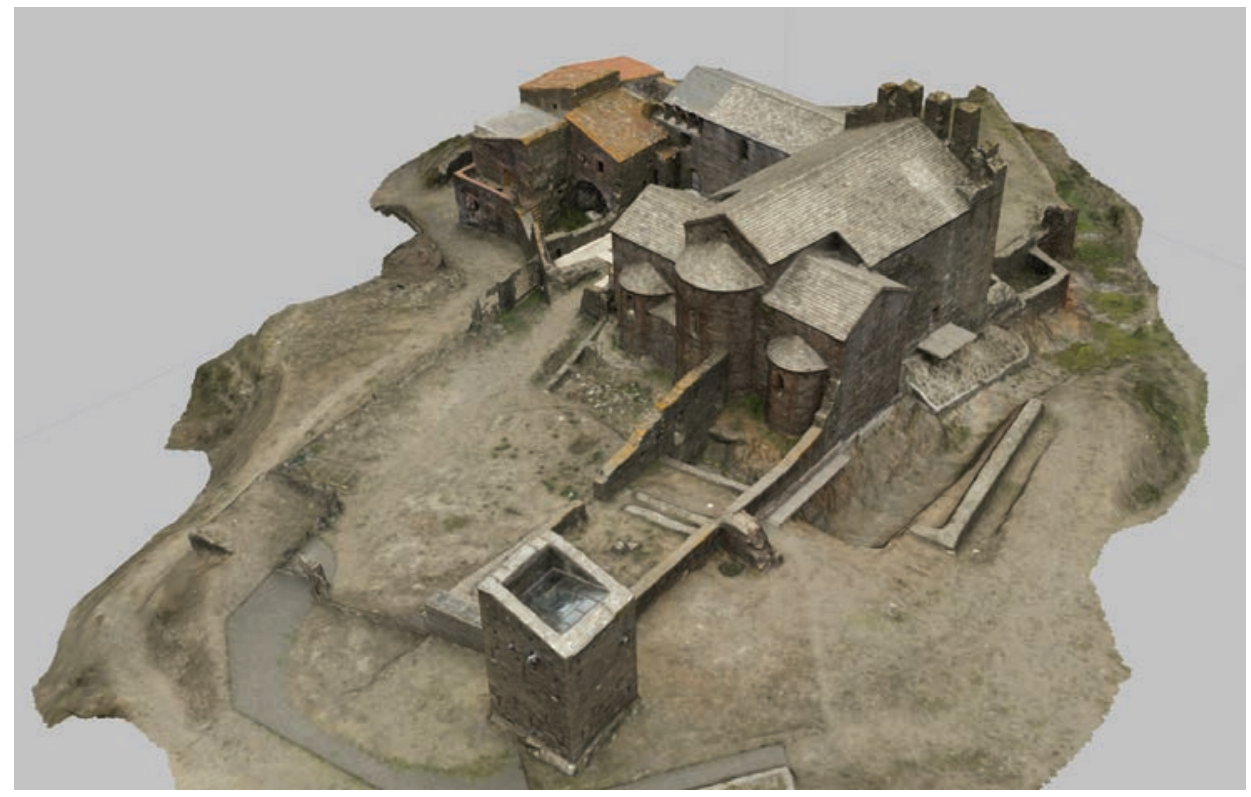

Fig. 7. Modelado fotogramétrico 3D. Formación de modelo de malla 3D texturizada (ECLOC/LFA). Un tercer dron, de tamaño más reducido, fue utilizado para la captura de vídeos e imágenes complementarias. En los vuelos realizados en la campaña del 2015 las alturas de operación estuvieron marcadas entre los $110 \mathrm{~m}$ y $65 \mathrm{~m}$, ofreciendo resoluciones efectivas -tamaño medio del pixel en el terreno- de entre 4 y $2 \mathrm{~cm}$ respectivamente. Gracias a estas imágenes, se obtuvo una ortoimagen de planta extendida de la zona del valle donde se emplaza el monasterio y otra, de más detalle, limitada al conjunto edilicio. Esta ortofoto, aun siendo de gran calidad y superando en resolución a todos los documentos preexistentes, se demostró insuficientemente detallada para la restitución de los elementos arquitectónicos y arqueológicos relevantes. Por ello, en la campaña de 2016, se redujo la altura de vuelo hasta los 3om y se eligió una lente de mayor longitud focal logrando una resolución efectiva de pixel mejor a $4 \mathrm{~mm}$.

La documentación gráfica conseguida supera ampliamente los resultados de métodos tradicionales de producción cartográfica mediante aviones tripulados. Asimismo, gracias a la multiplicidad de puntos de vista, se hace posible un nivel de redundancia altísimo que permite construir modelos $3 \mathrm{D}$ mucho más rigurosos. Gracias a estos modelos, es posible obtener ortoimágenes en las que la deformación de la perspectiva se reduce a límites imperceptibles. Es lo que se conoce como 'ortofoto verdadera' (True-Ortho) por contraposición a aquella en la que la rectificación es solo parcial, apareciendo algunos paramentos proyectados o deformados. Los vuelos de la campaña del 2016 han permitido obtener una resolución mucho mayor y una ortofoto aún más rica en detalle, logrando en estas ortoimágenes que cada píxel corresponda a $2 \mathrm{~cm}$ de la realidad, diferenciándose de las ortofotografías oficiales habituales, donde el pixel rara vez es menor a $20 \mathrm{~cm}$. Cabe destacar también otro resultado del proceso de documentación, los modelos digitales de elevación de alta resolución basados en las nubes de puntos. Estos reproducen las irregularidades del terreno, obteniendo de forma automática las representaciones de relieve por curvas de nivel y tintas hipsométricas.

Toda la documentación sobre la que trabaja el equipo ECLOC sobre Sant Quirze de Colera se basa en el modelo tridimensional. Gracias a la metodología utilizada y el material métrico generado es posible interrogar al edificio tal como se observa en los primeros resultados que aquí se presentan.

\section{SISTEMA DE INFORMACIÓN ESPACIO-TEMPORAL}

El conjunto de Sant Quirze de Colera, como se ha visto ya hasta aquí y como se verá más adelante, es una realidad compleja. Es sabido por todos que el estudio de edificios o conjuntos históricos conlleva hacer frente a un amplio repertorio de datos esencialmente arqueológicos, arquitectónicos y documentales, entre otros ${ }^{21}$. Abordar su estudio plantea un reto importante, el de almacenar e interrelacionar de forma lógica y ordenada todo este tipo de informaciones con la finalidad de poder observar e interrogar al monumento desde múltiples perspectivas. Es necesario crear una estructura de datos sobre la cual poder trabajar realmente de forma interdisciplinar, que además se pueda actualizar, analizar y medir, y sugiera hipótesis contrastables, en definitiva, un instrumento que permita ir más allá de la pura y mera documentación.

\section{Establecimiento de una metodología crono-estratigráfica}

El proyecto establecido para el análisis crono-estratigráfico de las estructuras monásticas de Sant Quirze de Colera, se fundamenta -desde el punto de vista metodológico- en dos conceptos o ideas: la de modelo espacio-temporal y la de sistema de información.

La construcción de un modelo espacio-temporal del conjunto obliga a identificar los acontecimientos, es decir, los hechos históricos, que en él se han ido sucediendo. Es necesario definirlos a partir de dos/tres coordenadas espaciales y una temporal, ordenarlos de forma lógica, para así poder operar con ellos. A nadie se le escapa que este es precisamente el objetivo que persigue el método estratigráfico

\footnotetext{
${ }^{21}$ Véanse las consideracions que planteamos en cuanto al estudio integral de la arquitectura y en relación al CARE-Hispania: G. RIPOLL, E. CARRERO, D. RICO, F. TUSET, I. VELÁZQUEZ, A. LÓPEZ BATLLE, C. MAS, M. VALLS y M.Á. CAU, "La arquitectura religiosa hispánica del siglo IV al X y el proyecto del Corpus Architecturae Religiosae Europeae - CARE-Hispania", Hortus Artium Medievalium 18/1 (2012), 45-73.
} 


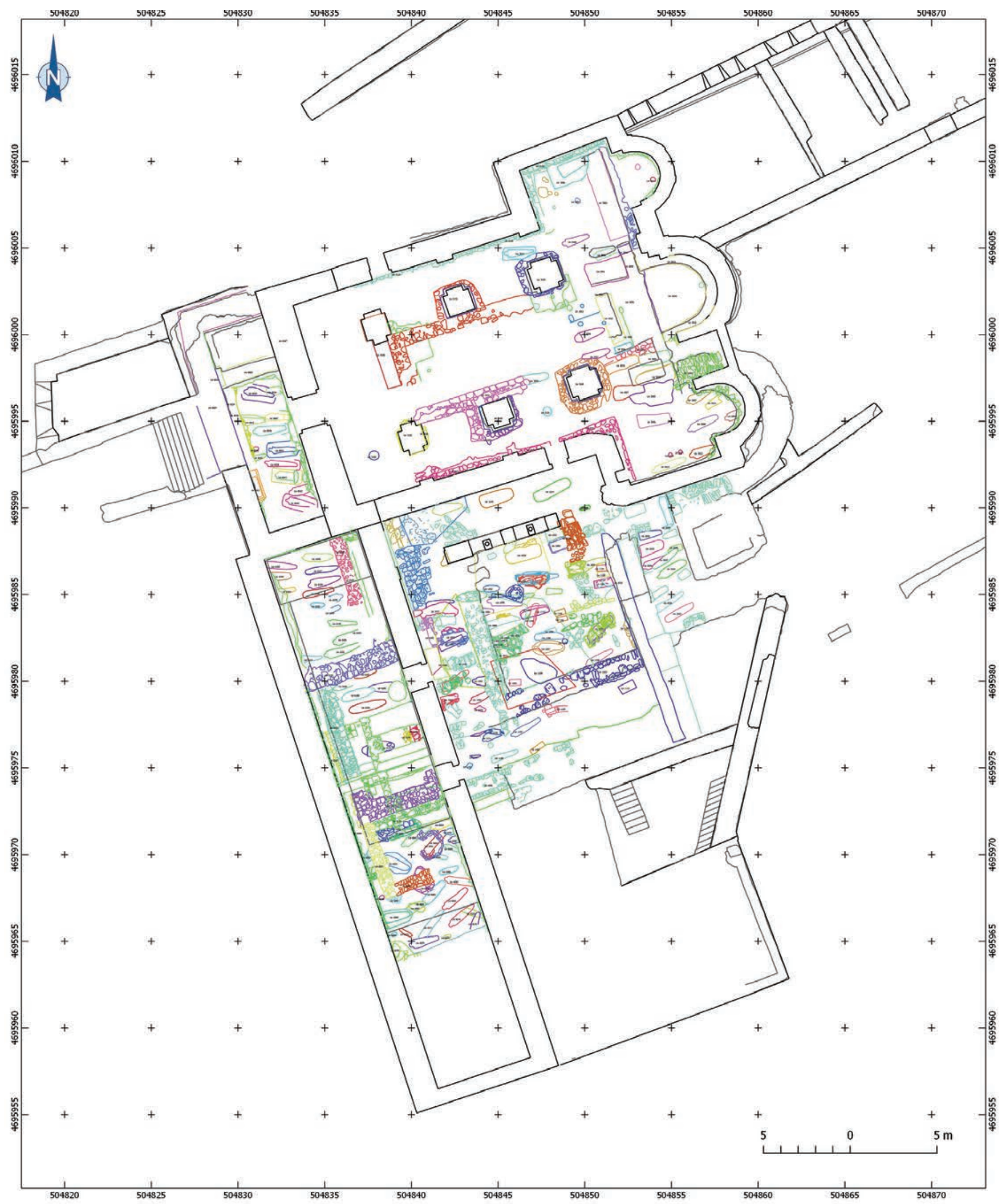

Fig. 8. Planta digitalizada con todos los datos estratigráficos (trabajo en curso) (ECLOC/J. Benseny, F. Tusety G. Ripoll).

en sí. De este modo, la principal herramienta de trabajo es la Unidad Estratigráfica (Ue), entendida como un acontecimiento, hecho o suceso, es decir, como contenedor de información perfectamente confinado por sus dimensiones espacio-temporales. Partimos de la premisa que la Ue es la herramienta más eficiente, sino la única, para descomponer una realidad compleja, la del conjunto histórico, en partes manejables, comprensibles y operativas. La estrategia del análisis se basa en aislar cada Ue permitiendo así un conocimiento más preciso de la secuencia diacrónica y/o sincrónica del monumento y las diferentes estructuras arquitectónicas que lo componen. 


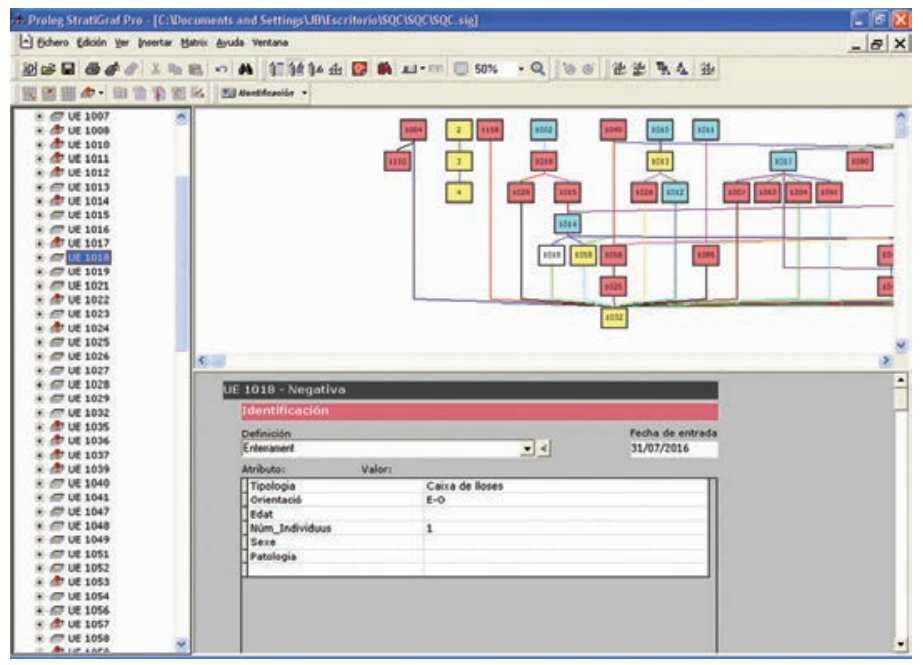

Fig. 9. Introducción de datos estratigráficos en el software Proleg StratiGraf (trabajo en curso) (ECLOCIJ. Benseny, F. Tuset y G. Ripoll).

Las técnicas de documentación gráfica aportan las dimensiones espaciales, el cálculo estratigráfico la dimensión temporal y los estudios interdisciplinares la información contenida en cada Ue, información que puede ser cuantitativa, analítica o contextual.

Una vez obtenida la secuencia estratigráfica y la documentación gráfica se dispone ya de la estructura principal del modelo espacio-temporal. Se trata de un primer orden lógico basado en unas normas también lógicas que no se podrán transgredir en los pasos siguientes. Establecida esta estructura vertebral se procede a dotarla de contenido, de información, iniciándose así el proceso de construcción de la secuencia crono-estratigráfica. El objetivo es establecer una aproximación razonada e interdisciplinar al conocimiento de datos espacio-temporales, sobrepasando la simple crónica de los hechos. De lo que se trata es de comprenderlos, contextualizarlos y explicarlos.

Este primer paso es fundamental. Dotar al modelo de una estructura principal significa poder gestionar los diferentes tipos de datos e informaciones que generan y usan los investigadores que participan en el proyecto desde sus diferentes disciplinas científicas. Intervienen de forma complementaria, pero a su vez, solapada, todas las cuestiones derivadas de la arqueología y el registro estratigráfico, las fuentes textuales y los datos históricos, las discusiones sobre el estilo, la organización y función litúrgica de los espacios, las técnicas constructivas, los cálculos estructurales, las patologías, la obtención de las materias primas, las dinámicas geológicas, los datos geométricos, y un largo etcétera, como es lógico en el estudio de cualquier arquitectura de gran diversidad y proyección temporal. Son todos estos factores y condicionantes los que han obligado a pensary diseñar un sistema de información que se ajustase a la complejidad de los datos, a los requerimientos de la investigación, al trabajo interdisciplinar y ubicuo.

\section{Implementación metodológica}

La implementación metodológica, teniendo en cuenta lo que se ha dicho en el apartado anterior, está en curso. Se ha procedido, en primer lugar, a recuperar toda la información disponible de las intervenciones arqueológicas, pero también las de consolidación y restauración arquitectónicas (cf. supra), realizadas en el conjunto desde el año 1997 hasta el año 2012, y lo que ello significa para su comprensión, evaluación y ordenación. Todas las intervenciones se basaron genéricamente en el método estratigráfico, si bien, dado que la dirección de la excavación no recayó siempre sobre el mismo arqueólogo, el criterio de aplicación y registro estratigráfico es dispar. La profunda revisión nos ha obligado a definir un método estándar con el objetivo de integrar la información pasada, presente y futura de forma consistente, coherente y lógica.

En segundo lugar se ha digitalizado y georeferenciado la información gráfica conservada en soporte en papel, casi exclusivamente plantas generales. Posteriormente, todo este material ha sido vectorizado mediante $\mathrm{CAD}$, individualizando cada una de las Unidades Estratigráficas. Sin ningún género de dudas es el primer paso -imprescindible entre otras cuestiones también relevantes- dado que proporciona la necesaria consistencia al registro estratigráfico para comprender, revisar y actualizar la gran masa de datos antes mencionada (fig. 8).

$\mathrm{Al}$ mismo tiempo se ha reconstruido el registro estratigráfico mediante el uso del software Proleg StratiGraf, un sistema de información estratigráfico que facilita el registro, automatiza el proceso de cálculo estratigráfico y la obtención de la secuencia estratigráfica. Este software permite gestionar -a su vez- el dibujo 2D desde la estratigrafía (fig. 9).

El proceso para unificar la información relativa a las excavaciones antes indicadas, plantea grandes inconvenientes, la mayoría de ellos derivados del criterio metodológico que se usó en cada intervención. El principal problema viene dado por no disponer, en ningún caso, de una información gráfica individualizada Ue a Ue. Esta limitación se ha podido subsanar, en gran parte, a partir de las plantas generales que no secciones, pero con la consecuente pérdida de información y de detalle. Otro problema es el que plantean las escasas o excesivamente concisas descripciones de las Unidades Estratigráficas, a lo que se suma la falta de información fotográfica para cada una de ellas, dificultando la reinterpretación. A esta situación se agregan otras dos de gran relevancia: la práctica ausencia de Unidades Estratigráficas negativas y la inexistencia de plantas de estrato, sólo analizables a partir de las pocas secciones. La metodología del registro arqueológico-estratigráfico obliga a la documentación de las Ue negativas y al dibujo en planta y sección de cada una de ellas; su ausencia, merma, por no decir invalida, una posible interpretación o lectura crono-estratigráfica. El trabajo que se está realizando dentro del proyecto no es una simple transcripción y digitalización de datos, es -hasta donde la información lo permite- una reinterpretación del registro estratigráfico.

En tercer lugar, se está procediendo a incorporar en el registro estratigráfico creado todos los estudios estratigráficos que se están acometiendo en la actualidad, especialmente el análisis constructivo y de paramentos, que no ha sido nunca realizado y que consideramos de absoluta necesidad para comprender la secuencia crono-estratigráfica y constructiva de las estructuras del conjunto monástico. Nos preocupa, de manera muy especial, el buscar la correlación o la continuidad entre Unidades Estratigráficas con una visión de conjunto, ya que al ser anotadas sólo parcialmente en las anteriores excavaciones, no proporcionan una documentación, y por tanto interpretación, de forma fidedigna.

El otro punto importante del proceso de trabajo, en cuarto lugar, es generar la base del modelo espacio-temporal 
mediante la creación de una base de datos espacial que unifica y hace operativos los tres principales componentes del registro estratigráfico: la Unidad Estratigráfica (el contenedor de información), su geometría (la dimensión espacial) y su posición estratigráfica (dimensión temporal).

La base de datos espacial se ha implementado en PostGIS un módulo GNU GPL que añade soporte a objetos geográficos para el sistema de administración de bases de datos PostgresSQL siguiendo los estándares de los Sistemas de Información Geográfica.

Mediante la conversión del dibujo vectorial a geometrías tipo Well-Known Binary (WKB) y la carga de datos estratigráficos y descriptivos procedentes de Proleg StratiGraf se obtiene una potente herramienta de análisis a partir de consultas SQL (Structured Query Language). Es lo que se conoce como 'construir realidades'. Para ello, simplemente es necesario conectar la base de datos PostGIS a alguno de los numerosos SIG de escritorio que lo pueden usar.

De este modo, por ejemplo, una consulta que indique cuales son las relaciones estratigráficas de anterioridad de una Unidad Estratigráfica determinada, dibuja una planta compuesta por el conjunto de los dibujos individuales de cada una de las Ue con las que mantiene dicha relación. Esta consulta es lo que se denomina: construir la realidad anterior de una Ue. Este tipo de consulta no es baladí, es especialmente útil, junto con la de construcción de la realidad posterior, para testear relaciones estratigráficas. Incluso se pueden recorrer paso a paso los niveles de la secuencia crono-estratigráfica por periodos, o fases o momentos, construyendo con la consulta las correspondientes plantas.

El modelo espacio-temporal es el único instrumento que ofrece la posibilidad de visualizar a través de la composición gráfica todas las consultas necesarias, ya sea para comprender, para detectar errores o para contrastar hipótesis, sumamente difíciles de percibir de otro modo.

Por último, en cuanto a la implementación metodológica, se está ahora ampliando la estructura de datos del modelo espacio-temporal, teniendo en cuenta lo dicho más arriba, que toda Unidad Estratigráfica es un contenedor de información, al igual que lo son las agrupaciones de Ue, acciones, momentos, fases o períodos. La estructura primaria de la base de datos espacial debe ir desplegándose ad hoc integrando los elementos que se están generando en el proceso de investigación interdisciplinar. Sólo así puede ser construido el sistema de información del conjunto.

\section{Retos de futuro}

El manejo de datos y geometrías $2 \mathrm{D}$ o $3 \mathrm{D}$ en formato vectorial construyendo un modelo espacio-temporal es asequible, tal como se ha visto, dado que se dispone de la tecnología necesaria para hacerlo, ampliamente desarrollada para los Sistemas de Información Geográfica y de fácil uso.

Sin embargo, el análisis estratigráfico actual se ha basado en nuevas técnicas de documentación gráfica (láser scannery fotogrametría a partir de imagen digital), dirigidas básicamente a la generación de un modelo tridimensional del cual se extrae información tanto en $2 \mathrm{D}$ como en $3 \mathrm{D}$, así como información fotogramétrica y modelos de elevación del terreno, entre otros. Los modelos de datos obtenidos con estas técnicas son más difíciles de gestionar y no se dispone de herramientas lo suficientemente desarrolladas para poderlos integrary hacerlos operativos según demanda nuestro método. Es necesario poder diseccionar un modelo tridimensional de puntos (point cloud) Ue a Ue para así integrar y gestionar dicha información a partir de la base de datos espacial y disponer de un módulo para la base de datos dotado de las funciones imprescindibles para realizar operaciones geométricas, extraer o simplificar información (geometrías 3D simples, ortofotografías...) y crear mallas, texturas o renderizar.

Con un modelo espacio-temporal tridimensional que incorpore estas características obtendremos un constructor de 'realidades' mucho más eficiente, más precisoy más comprensible que el que se consigue a partir de la información vectorial citada con anterioridad. La solución a este reto planteado por el proyecto ECLOC el año 2016 se inició con un proyecto experimental de transferencia tecnológica financiado por la Comunidad de Castilla y León, junto al Grupo de Investigación Reconocido MoBiVAP / Modelado, Biomecánica y Visualización Avanzada del Patrimonio integrado en el Departamento de Álgebra, Análisis Matemático, Geometría y Topología de la Escuela Técnica Superior de Ingeniería Informática de la Universidad de Valladolid. El proyecto en sí tiene como objetivo atender nuestros requerimientos para desarrollar un sistema de información estratigráfico (modelo espacio-temporal) capaz de gestionar todo tipo de información $2 \mathrm{D}$ y $3 \mathrm{D}$, especialmente centrado en solucionar la integración y la explotación de los datos tridimensionales que se obtienen con las nuevas tecnologías geomáticas ${ }^{22}$.

\section{UNA PRIMERA APROXIMACIÓN A LAS FUENTES TEXTUALES}

La cuestión de las fuentes textuales que - directa o indirectamente- están en relación con el monasterio de Sant Quirze de Colera es, por decirlo de alguna manera, todavía un tema pendiente, lo mismo que el abaciologio, que debe ser acometido por los investigadores dado que su recopilación y minucioso estudio ha de permitir establecer, junto con el análisis estratigráfico, la secuencia histórica y arquitectónica del conjunto. Una gran parte de la documentación textual se encuentra en el Archivo de Besalúk ${ }^{23}$, dado que el monasterio de Sant Quirze fue agregado al de Sant Pere de Besalú por el Papa Clemente VIII en 1592.

Durante la desamortización de Mendizábal en 1836-1837, las fuentes escritas se trasladaron al Archivo de la Delegación de Hacienda de Girona, donde se concentró la mayor parte de la documentación monacal de la diócesis gerundense. Fue en este archivo donde Francesc Montsalvatje i Fossas estudió y transcribió algunos textos íntegramente, elaborando resúmenes amplios de otros ${ }^{24}$. En 1918 los fondos documentales se trasladaron a la Sección de Monacales del

\footnotetext{
${ }^{22}$ El registro estratigráfico $3 \mathrm{D}$ es un hecho que se reclama ya desde importantes foros científicos, véase J. REU, P. DE SMEDT, D. HERREMANS, M. VAN MEIRVENNE, P. LALOO y W. DE CLERCQ, “On Introducing an Image-Based 3D Reconstruction Method in Archaeological Excavation Practice", Journal of Archaeological Science, 41 (2014), 251-262.

${ }^{23}$ J. M. SALRACH, "Els documents de Besalú a l'Arxiu Comtal de Barcelona i els misteris del darrer comte de Besalú (segles XI-XII)", Quaderns de les Assemblees d'Estudis, 1 (2014), 7-28 (p. 9).

${ }^{24}$ M. BAIG I ALEU, "La fundació de la vila de Sant Miquel de Colera”, Annals de l'Institut d'Estudis Empordanesos, 20 (1987), 229-273 (p. 232).
} 
Archivo de la Corona de Aragón, aunque muchos textos ya se habían extraviado porque fueron adquiridos por particulares $^{25}$. Actualmente se conserva sólo una pequeña parte de la documentación de los siglos IX al XII y se dispone de las transcripciones de F. Montsalvatje, publicadas en su obra Noticias Históricas, en el volumen correspondiente a los monasterios del condado de Besalú ${ }^{26}$.

La primera fuente escrita referida al monasterio es el denominado 'Juicio sobre los bienes del monasterio de Sant Quirze de Colera', con fecha del 21 de mayo del año 844. El texto original se extravió y sólo se han conservado dos copias posteriores: una del siglo XIII en el Archivo Episcopal de Girona y un extracto interpolado del siglo XIX en el Archivo de la Mensa Episcopal de $\mathrm{Vic}^{27}$. Fue publicado, transcritoy traducido por Jaume Villanueva en 1850 y por Francesc Montsalvatje en 1896. Sea como fuere, la autenticidad de dicho documento todavía genera controversia entre los historiadores. Jaume Villanueva ${ }^{28}$ apuntaba que aunque el texto sufra interpolaciones de siglo XIII como las firmas, no se puede asegurar que se trate de una falsificación íntegra. Los datos sobre el contexto histórico son acertados y se pueden corroborar con textos del siglo IX, como los documentos escritos que sitúan a Gotmar como obispo de Girona como mínimo desde el 841 hasta el 850 y una sentencia del 842 donde aparece el conde Alarico, todos ellos citados en el juicio del 844.

El documento reseña un juicio entre Alarico, conde de Empúries-Peralada, y Guiemundo, monje de Sant Quirze, por la potestad del monasterio, sus tierras y Castro Tolon, hoy Peralada. El monje defiende los dominios del monasterio aludiendo a un supuesto precepto de Carlomagno. Según este, Libencio, el tío del monje, y su padre, Asenario, ocuparon el castillo de Tolon y todas sus tierras y construyeron el monasterio de Sant Quirze. Tras su muerte, la propiedad de todos los bienes pasó al monasterio de Sant Quirze y a los que vivieran allí siguiendo una existencia monacal. Cabe destacar la doble advocación de la iglesia del monasterio a san Quirico y san Andrés.

El mismo texto aporta igualmente referencias temporales que permiten ceñir con cierta precisión los orígenes fundacionales del monasterio. El texto cita ...et judicaverunt totum hoc predictum secundum ipsorum voluntatem per $X L$ annos... indicando que Libencio y Asenario controlaron todo este territorio durante más de cuarenta años. La frase siguiente clarifica otro dato temporal: Et dum erimus ibi domini possessores post mortem illorum per $X$ annos et amplius sic venit dictus Alarius comes et depotestavit nos injuste..., el conde Alarico quiso apropiarse de los territorios dependientes del monasterio pasados diez años de la muerte de Libencio y Asenario. Más adelante, se insiste en estas cuestiones utilizando siempre el mismo vocabulario: ...est habere infra fines et terminis de omnibus predictis locis per XL annos..., y a continuación: Et dum essent domini possessores post mortem illorum per $X$ annos et amplius nos videntibus sic venit dictus Alaricus comes et depotestavit illos injuste...
Teniendo en cuenta estas referencias, si el monasterio controló todos estos territorios durante más de cuarenta años y diez más después de la muerte de Libencio y Asenario-momento que corresponde al intento de apropiación de Alarico- se deduce que se está refiriendo a cincuenta años atrás, es decir, hacia el año 794. En tal caso, el precepto de Carlomagno ratificaría una situación existente, dado que este no fue emperador hasta el año 8oo, por lo que la datación del precepto debería situarse entre el año 800 y el 814, momento de su fallecimiento. Las dataciones de ${ }^{14} \mathrm{C}$ de la segunda mitad del siglo VIII muestran un grupo que se entierra en el lugar en estas fechas, es decir, frecuentan y controlan el sitio y de ello puede deducirse que los documentos, que nos retrotraen al 794, más que de un inicio de actividad constructiva nos hablan de continuidad de la misma. En ese momento en el lugar se vive, se muere y se entierra.

La segunda fuente escrita sobre el monasterio de Sant Quirze de Colera, aunque de carácter menor, es la venta de una viña en el año 927. Sobre los textos de siglo X, destaca un documento del año 1771 transcrito por F. Montsalvatje $\mathrm{e}^{29}$, en el que el abad de Sant Pere de Besalú expone todos los documentos demostrando la pertenencia del valle de Colera al monasterio de Sant Quirze. Esta fuente documental informa de una donación al monasterio en el año 928, momento fundamental en la expansión del dominio territorial de la abadía. La donación por parte de los ejecutores testamentarios del conde Gausberto marcó la incorporación del valle y el término de Colera a la propiedad del monasterio. Igualmente, del año 965, destaca una donación del hijo de Gausberto. Ambas dádivas son representativas del aumento de donaciones de bienes al monasterio durante el siglo X.

Uno de los documentos más interesantes para el estudio arquitectónico y arqueológico del conjunto monacal es el acta de consagración del año 935 con la triple advocación: san Quirce, san Andrés y san Benito (Quirze, Andreu y Benet) ${ }^{30}$. El texto relata las obras de reconstrucción promovidas por el abad Manuel: domini Wigoni videlicet cum plerisque suplicationibus proprii abbatis Manuel eclesiarum sancti Cirici sancti Andree et sancti Benedicti reedificatione sumpsit exordium.... Más adelante incide en las características de dicha obra: Subsequens profecto abbatibus prioribus qui eisdem sepe familiaritate acti sunt qui funditus ab eclesiis inutilia dejecit et reparationis copie ornamenta reparavit caucibus et petris utilitas reformavit lucris quibus imperavit, signorum, palliorum et universorum opibus proutquivit laboribus propriis honestavit, es decir: la retirada de elementos o 'cosas inútiles' de las iglesias, la reparación haciendo uso de múltiples ornamentaciones, la restauración del uso con sillares y piedras, y con los recaudos que ordenó y su propio trabajo, las agenció de imágenes, casullas y de todas las cosas necesarias.

El vocabulario utilizado en la redacción del texto -reedificatio/reedificación, reparatio/reparación y reformare/ reforma- revelan la existencia de un edificio anterior, y la alusión a abades precedentes confirma el carácter monacal del edificio previo a la consagración del año 935.

\footnotetext{
${ }^{25}$ J. M. SALRACH, op. cit. (n. 23).

${ }^{26}$ F. MONTSALVATJE, Noticias históricas. Monasterios del antiguo condado de Besalú (Olot: Imprenta y librería, 1886) VIII.

${ }^{27}$ J. BADIA I HOMS et al., Sant Quirc (o Sant Quirze) de Colera, Catalunya Romànica IX, L'Empordà II (Enciclopèdia Catalana, Barcelona, 1990), 753-773 (p. 754) (subseq. ref.: Catalunya Romànica IX, II).

${ }^{28}$ J. VILLANUEVA, Viaje literario a las iglesias de España (Madrid: Real Academia de la Historia, XIII, 1850), p. 18.

${ }^{29}$ F. MONTSALVATJE, op. cit. (n. 26).

$3^{30}$ Transcrito y traducido por F. MONTSALVATJE, op. cit. (n. 23), cap. XXX. Con acertadas correcciones de R. ORDEIG I MATA, Les dotalies de les esglésies de Catalunya (segles IX-XII) (Vic, 1993), I.1, p. 126.
} 


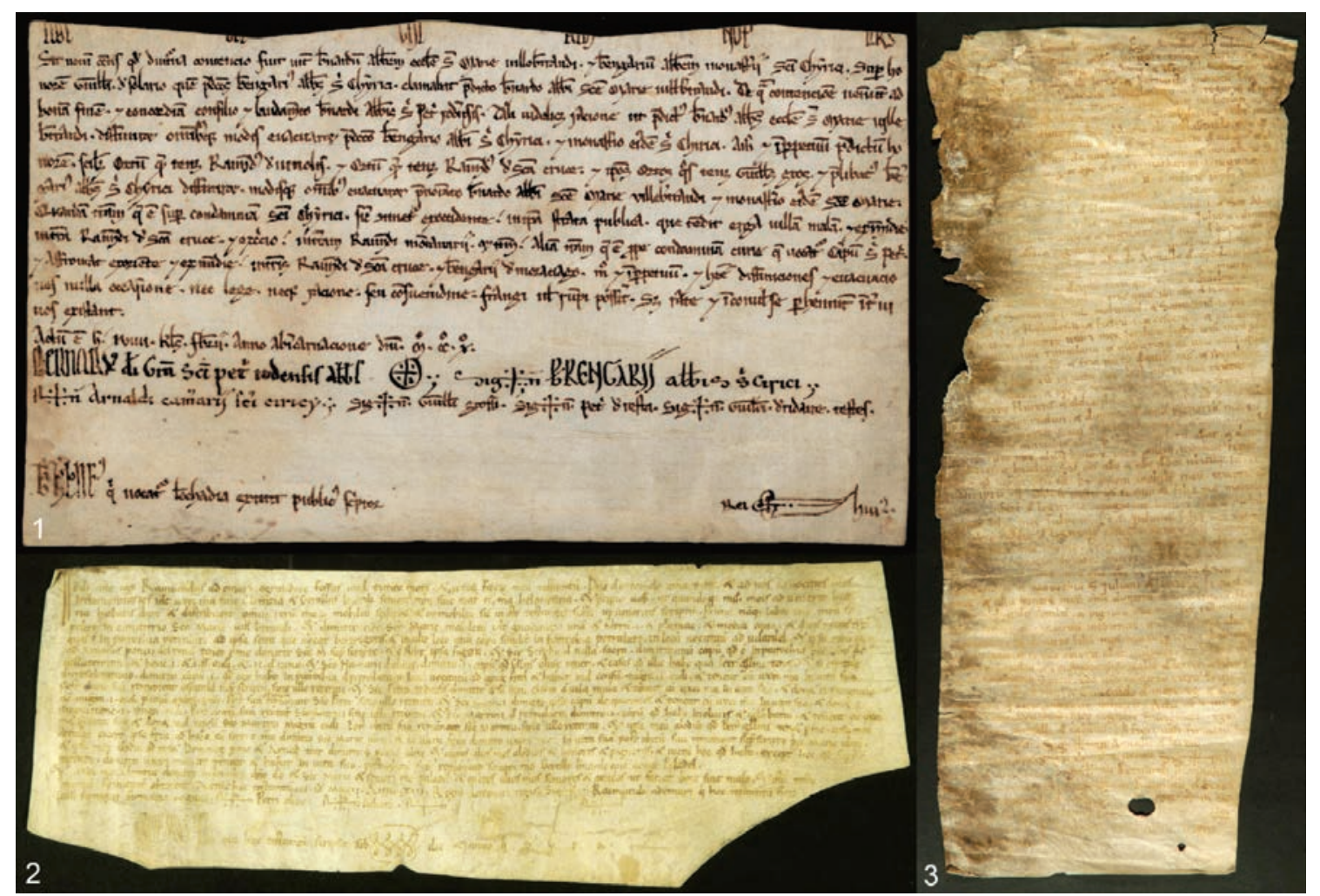

Fig. 10. Textos menores de los siglos XII y XIII. 1. Arbitraje del abad de Sant Pere de Rodes en una causa entre los abades de Santa Maria de Vilabertran y Sant Quirze de Colera sobre unas posesiones, año 1211 (BC Perg. 137, Reg. 9671). 2. Testamento de Ramon Ademar, 1121, en el que dona un campo a Sant Quirze de Colera (BC Perg. 79, Reg. 9616). 3. Testamento de Arnau de Cabanes, 1125, dona limosnas al monasterio (BC Perg. 438, Reg. 9933). (BC=Biblioteca de Catalunya).

Del siglo XI sólo se han conservado dos documentos; uno referente a los nombres y las posesiones de los militum que tienen alodios en el monasterio ${ }^{31}$ y un juicio público del año 1012, en el que el monasterio reclama las tierras ocupadas por el vizconde Dalmau ${ }^{32}$. Del siglo XII, tres donaciones ${ }^{33}$, tres documentos referentes a los donativos de limosnas ${ }^{34}$, una venta ${ }^{35}$, una exención de pago ${ }^{36}$, un pleito ${ }^{37} \mathrm{y}$ un acta de consagración ${ }^{3}$. Es a partir de este siglo XII y a lo largo del siglo XIII, que la donación de diferentes tipos de posesiones, especialmente tierras, pasa a engrosar las propiedades del monasterio (fig. 10).

En 1123, el abad Berenguer consagró nuevamente la iglesia monástica y, por primera vez, la parroquial de Santa María, confirmando las posesiones que habían sido concedidas antiguamente y manteniendo la triple advocación citada en la consagración del año 935. En el texto del acta de consagración se menciona el traslado del altar de la iglesia de Santa María a la iglesia de Sant Quirze, donde se procedió a consagrarlo: Altare quoque sancte Marie quod fundatum fuerit in ecclesiola ante ianuas ipsius monasterii in ecclesiam sancti Circi translutimus et in honorem sancte Marie consecravimus. Cabe destacar la alusión a un precepto real que, por el momento, sólo se puede relacionar con el diploma

\footnotetext{
${ }^{31}$ Archivo Municipal de la Condal Vila de Besalú (AMB), perg. 11.002.

${ }^{32}$ Catalunya Romànica IX, II, p. 757 (n. 27).

33 Biblioteca de Catalunya (BC), perg. 79, reg. 9616; perg. 455, reg. 9970.

34 BC, perg. 438, reg. 9933; perg. 455, reg. 9972; perg. 431, reg. 9819.

${ }^{35} \mathrm{AMB}$, perg. 13.002.

${ }^{36} \mathrm{AMB}$, perg. 13.003 .

${ }^{37}$ Citado en Catalunya Romànica IX, II, p. 758 (n. 27).

${ }^{38}$ Transcripción de F. MONTSALVATJE, op. cit. (n. 23), cap. XXXI, pp. 188-191.

39 BC, perg. 438, reg. 9947.

${ }^{40}$ Catalunya Romànica IX, II, p. 753 (n. 27).
}

concedido por Carlomagno mencionado en el juicio del año 844: Quae antiqitus concessa sunt atque collata jam dictae ecclesiae Sancti Cirici a regibus et comitibus sive aliis bonis hominibus et a predecessore nostro Guigone episcopo, sicut in alia dote et preceptis regalibus resonat, es decir, desde antiguo fueron concedidas a la citada iglesia de Sant Quirze por los reyes, condes y otras personas de bien, y por nuestro predecesor el abad Guigo, tal como figura en otro documento de donación y en los preceptos reales.

Los documentos relacionados con compras por parte del monasterio no aparecen hasta el siglo XIII. De esta cronología, se conserva una gran cantidad de fuentes escritas que parecen reflejar un aumento en la actividad del monasterio. Se registran legados ${ }^{39}$, ratificaciones, sentencias y compras. Destacan, a su vez, dos bulas papales, la de Honorio III del año 1219 que confirma las iglesias y territorios del monasterio, y la de Inocencio IV de 1246, que ratifica la jurisdicción civil del monasterio y de las iglesias de Baussitges y Freixe ${ }^{40}$.

En 1285 el monasterio fue invadido por el ejército francés comandado por Felipe III de Francia, llamado el Atrevido, y en 1288 fue ocupado y saqueado por tropas de Jaume II de Mallorca. La Gesta Comitum Barcinonensium et regum Aragonum apunta que las tropas convirtieron el monaste- 

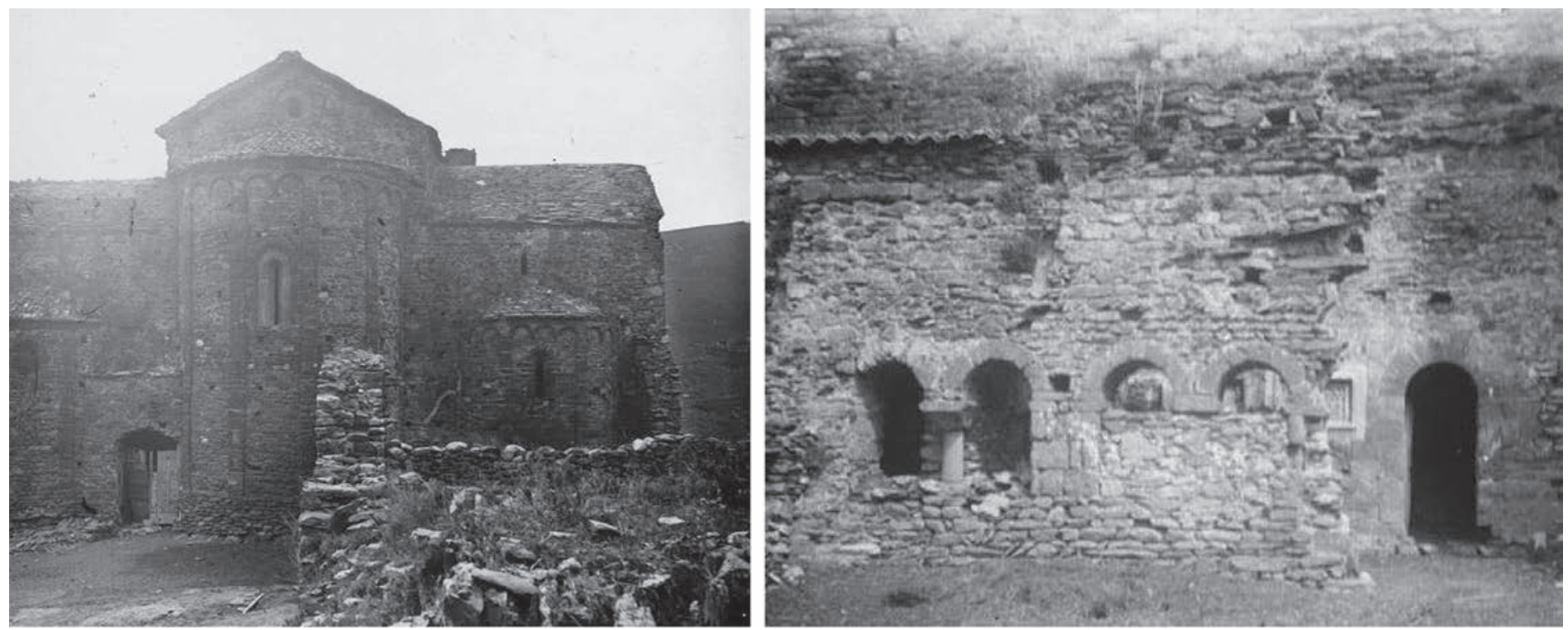

Fig. 11. Fotografias de inicios del siglo XX. Izq. Cabecera de la iglesia abacial en la que se observa la apertura realizada en la capilla situada entre los ábsides sur y central, J. Salvany i Blanc, 1918 (BC, Fons Salvany SaP 444 02). Dcha. Galería norte del claustro. La puerta corresponde al acceso sur de la iglesia abacial y se observan las piezas escultóricas todavía encastadas en la fábrica, C. August Torras, 1918 (Arxiu Fotogràfic del Centre Excursionista de Catalunya).

rio en un prostibulum immundorum/prostíbulo immundo y hace referencia a la profanación de las reliquias y a la destrucción de la ornamentación sagrada. El texto enuncia literalmente: Item fuit captum monasterium Sancti Cirici de Colera, et quod antea religione uigebat, tunc fuit prostibulum immundorum; fuerunt etiam sanctorum reliquiae pollutae, gentis immundis manibus attrectatae et exinde asportatae ${ }^{41}$.

Del siglo XIV se contabilizan en el Archivo de Besalú hasta once documentos ${ }^{42}$, la mayoría de ellos compraventas o arrendamientos de tierras, si bien uno de ellos esgrime las reglas internas del monasterio. Del mismo modo cabe mencionar una confirmación de los derechos del monasterio sobre sus iglesias y su derecho de jurisdicción civil y criminal por parte del conde de Empúries Ponç V el año 130343. En 1349, Ramon Berenguer, conde de Empúries, presentó un pleito al abad Pere reclamando la jurisdicción del pueblo de Rabós, que acabó perdiendo.

Por último, a lo largo del siglo XV se percibe ya una degradación del conjunto y dependencias monásticas dado que el número de fuentes desciende drásticamente; tenemos tan sólo constancia de tres documentos. La comunidad monástica se extinguió en 1592, momento en que el monasterio de Sant Pere de Besalú adquirió la propiedad de Sant Quirze de Colera por orden papal. En 1836-1837, en el contexto de la desamortización eclesiástica de Mendizábal, los terrenos que comprendían el monasterio fueron comprados por Ramón de Nouvilas i Ràfols. Los diferentes edificios pasaron a ser utilizados como casa para los arrendatarios, establos y almacenes de uso agrícola y ganadero ${ }^{44}$ (fig. 11).

\section{ESTUDIO HISTÓRICO-ARQUITECTÓNICO DEL CONJUNTO MONÁSTICO}

El conjunto arquitectónico de Sant Quirze de Colera está integrado, tal como se ha dicho precedentemente, por dos monumentos: la iglesia monástica y sus dependencias y la iglesia parroquial de Santa María, situada a occidente de la primera. Ambas forman una unidad histórica e institucional básica: integran el mismo complejo monástico y nos ofrecen un precioso ejemplo, pues los conservados no son tantos, de iglesia parroquial dependiente de un monasterio perteneciente a una orden contemplativa. Los dos edificios se encuentran separados unas decenas de metros y en planos topográficos diferentes, unidos por la vía de comunicación moderna que circunda la zona noroccidental de la iglesia monástica. El conjunto de edificios se extiende sobre un área de $5.122 \mathrm{~m}^{2}$ y la zona edificada propiamente dicha ocupa $2.481 \mathrm{~m}^{2}$.

\section{La iglesia monástica}

El monasterio de Sant Quirze es un complejo arquitectónico de difícil lectura en el que se distinguen hasta cinco estructuras homogéneas: la iglesia, el claustro y las dependencias de su lado oriental, el refectorio del lado occidental, la crujía que corre desde la cabecera de la iglesia en dirección este-oeste y las dependencias de la zona meridional del claustro, muy alteradas tras su uso como masía en época moderna y hasta el siglo XX. Indicamos desde buen principio las dimensiones de la iglesia abacial: longitud exterior 26,71m; long. interior 23,70m; anchura ext. 14,74m; anch. int. $12,2 \mathrm{~m}$; pero su long. int. era de 30,12 $\mathrm{m}$ y exterior de 31,65m si se tiene en cuenta la fachada oeste del edificio antes de su derrumbey posterior reconstrucción. La altura del edificio es por su interior de $12,58 \mathrm{~m}$ y el exterior de $13,90 \mathrm{~m}$. También es considerable, tal como se verá más adelante la longitud del transepto de $21,37 \mathrm{~m}$ por el exterior y $19,42 \mathrm{~m}$ por el interior (figs. 12, 13, 14 y 15).

Según Joan Badia i Homs ${ }^{45}$, que es el primer investigador que ha estudiado seriamente la arquitectura del monasterio,

${ }^{41}$ L. BARRAU-DIHIGO y J. MASSÓ I TORRENTS, Gesta Comitum Barcinonensium et regum Aragonum (Barcelona: Institut d'Estudis Catalans, 2007), p. 98, 7.9.

${ }^{42}$ AMB, Pergs. 14.001, 14.004, 14.006, 14.007, 14.016, 14.017, 14.002, 14.025, 14.028, 14.029, 14.030.

${ }^{43}$ Citado en Catalunya Romànica IX, II, p. 761 (n. 27).

${ }^{44}$ Catalunya Romànica IX, II, p. 761 (n. 27).

${ }^{45}$ J. BADIA I HOMS, L'arquitectura medieval de l'Empordà, vol. II.B, Alt Empordà (Girona, 1981), pp. 156-19o; cf. también Catalunya Romànica IX, II (n. 27). 


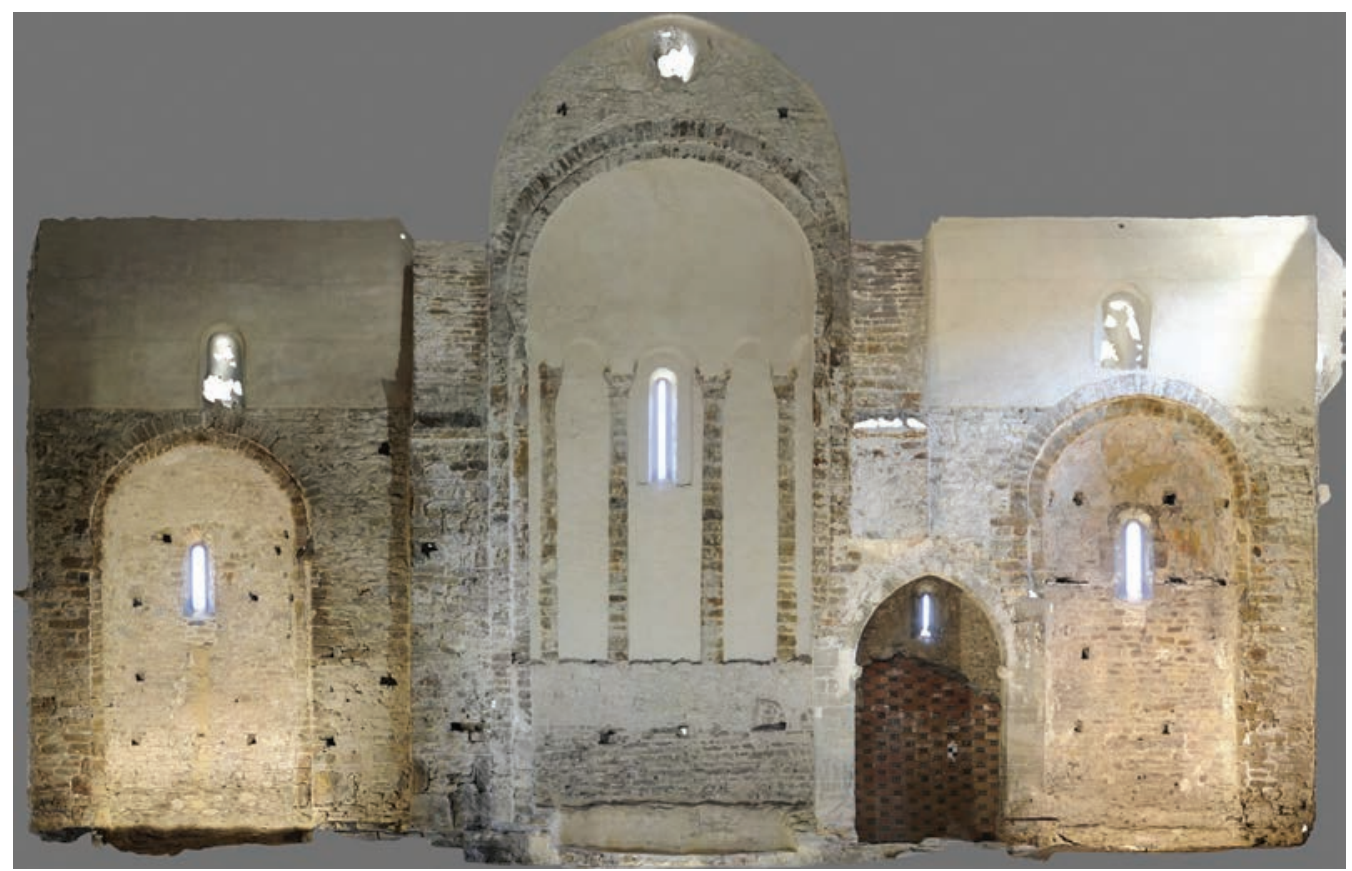

Fig. 12. Ortofotografia del alzado de la cabecera de la iglesia abacial por el interior (ECLOC/LFA).

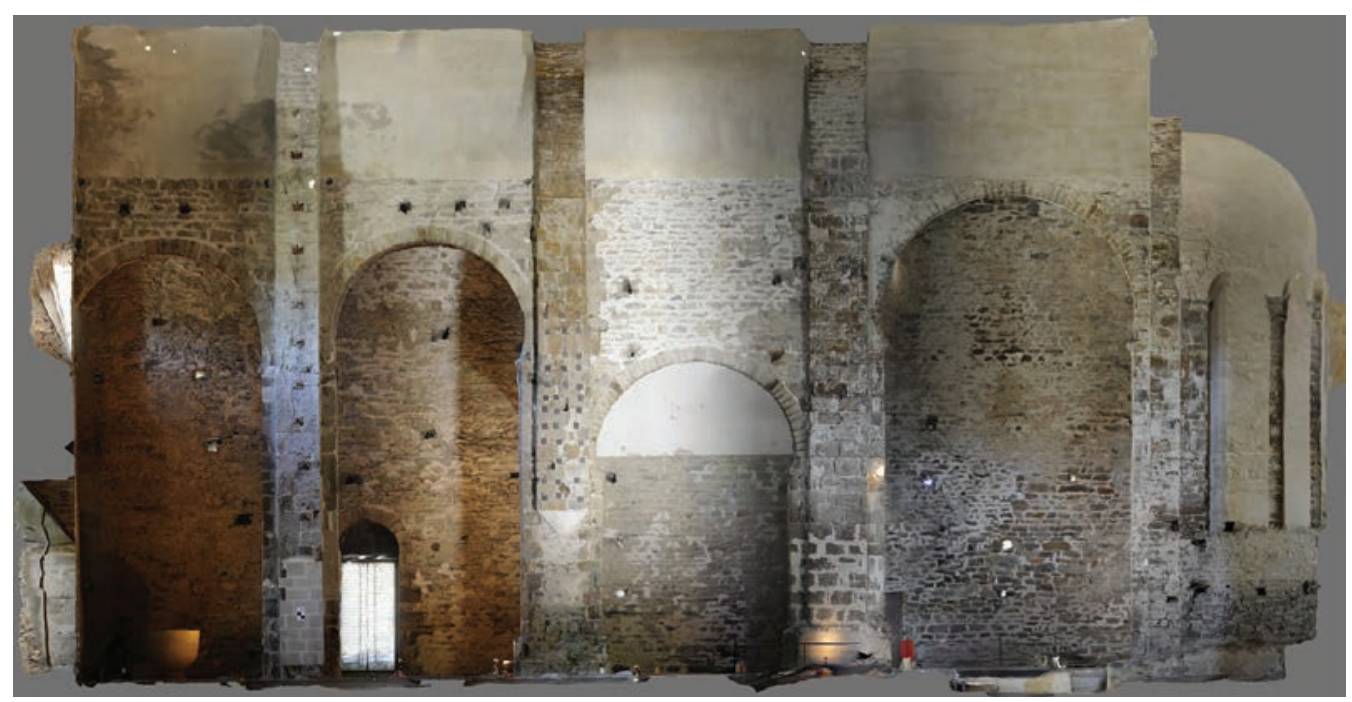

Fig. 13. Ortofotografía del alzado interior norte de la iglesia abacial (ECLOC/LFA).

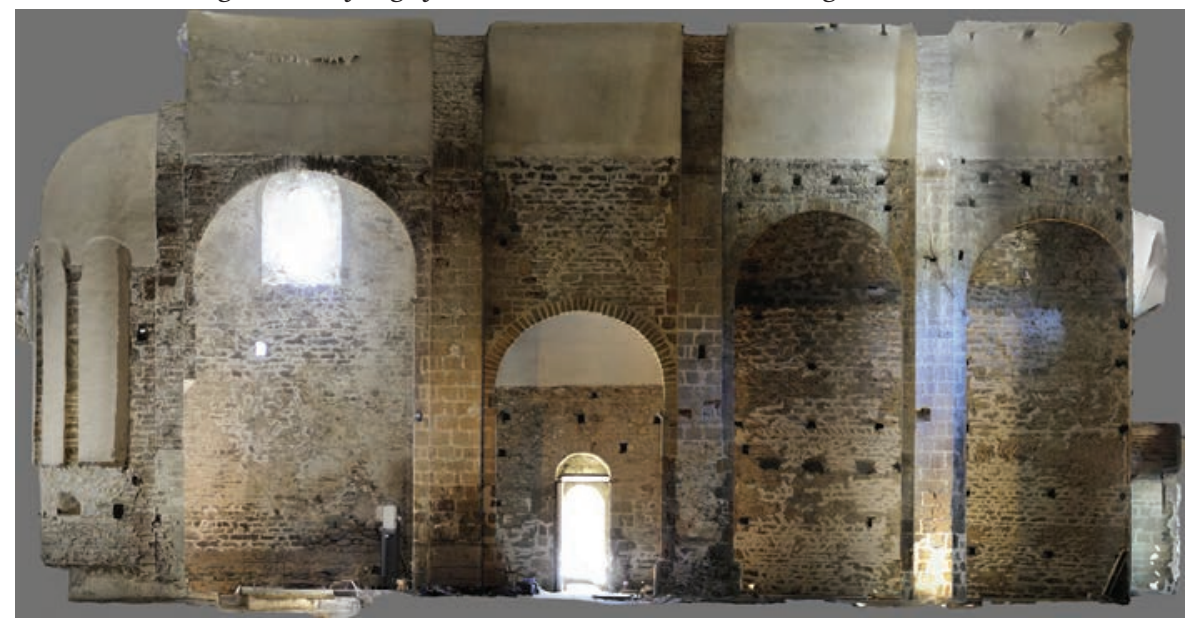

Fig. 14. Ortofotografia del alzado interior sur de la iglesia abacial (ECLOC/LFA). el muro semicircular hoy visible a nivel de cimentación en torno a la absidiola meridional de la iglesia románica, conformado por tres hiladas de piedra ligadas con mortero y dispuestas en opus spicatum, y la pequeña estancia cuadrangular que se eleva semiarruinada frente al transepto en el flanco oriental del claustro constituirían los únicos vestigios conservados de la primitiva iglesia monástica, construida en el siglo IX o a principios del siguiente con tres ábsides en la cabecera, el central semicircular (integrado más tarde en el edificio románico como basamento del ábside sur) y los laterales de planta rectangular. El edificio sería sustituido durante la prelatura del abad Manuel (927-935) por otro más amplio enteramente abovedado, con tres naves de cuatro tramos, destacado transepto y tres ábsides semicirculares, cuyo perímetro coincidiría sustancialmente con el de la iglesia actual (excepto en la parte de los pies) y del que ésta habría reaprovechado algunos de los lienzos en opus spicatum que se aprecian en distintos puntos de la caja de muros.

Otra bien distinta es la hipótesis planteada por Dolors Codina a partir de las intervenciones arqueológicas puestas en marcha en $1997^{46}$ y, sobre todo, de los sondeos y excavaciones realizados en el interior de la iglesia en 2002 y $2004^{47}$, que la han llevado a diso-

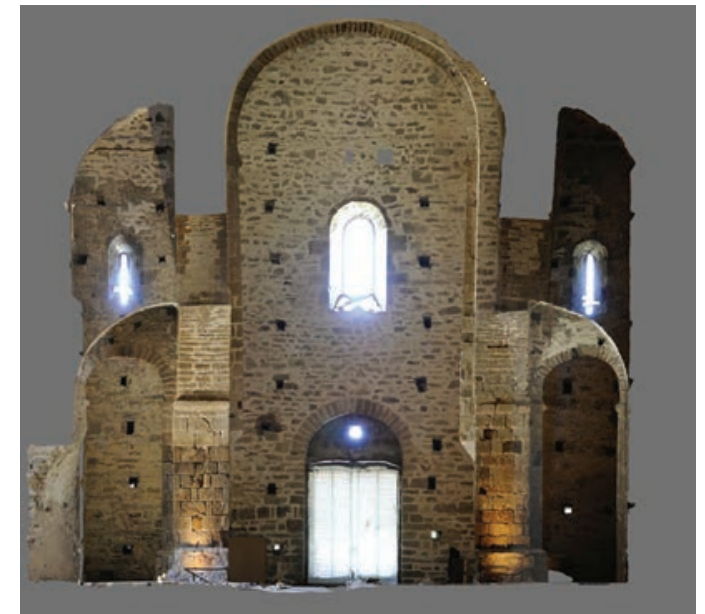

Fig. 15. Ortofotografia del alzado interior oeste de la iglesia abacial (ECLOC/LFA).

$\overline{{ }^{6} 6}$ D. CODINA, B. AGUSTÍ y M.TEIXIDOR, "Primers resultats de l'excavació del monestir medieval de Sant Quirze de Colera (Alt Empordà)”, Tribuna d'Arqueologia 1997-1998, 145-164.

${ }_{47}$ D. CODINA y C. MONTALBÁN, “L'època carolíngia a l'Albera: El cas de Sant Quirze de Colera (Rabós, Alt Empordà)”, III Congrés d’Arqueologia Medieval i Moderna a Catalunya, Sabadell, 18 al 21 de maig de 2006, (Sabadell, ACRAM, Ajuntament de Sabadell, 2007), 605-612. Cf. también: D. CODINA, op.cit. (n. 6), pp. 39-63. 

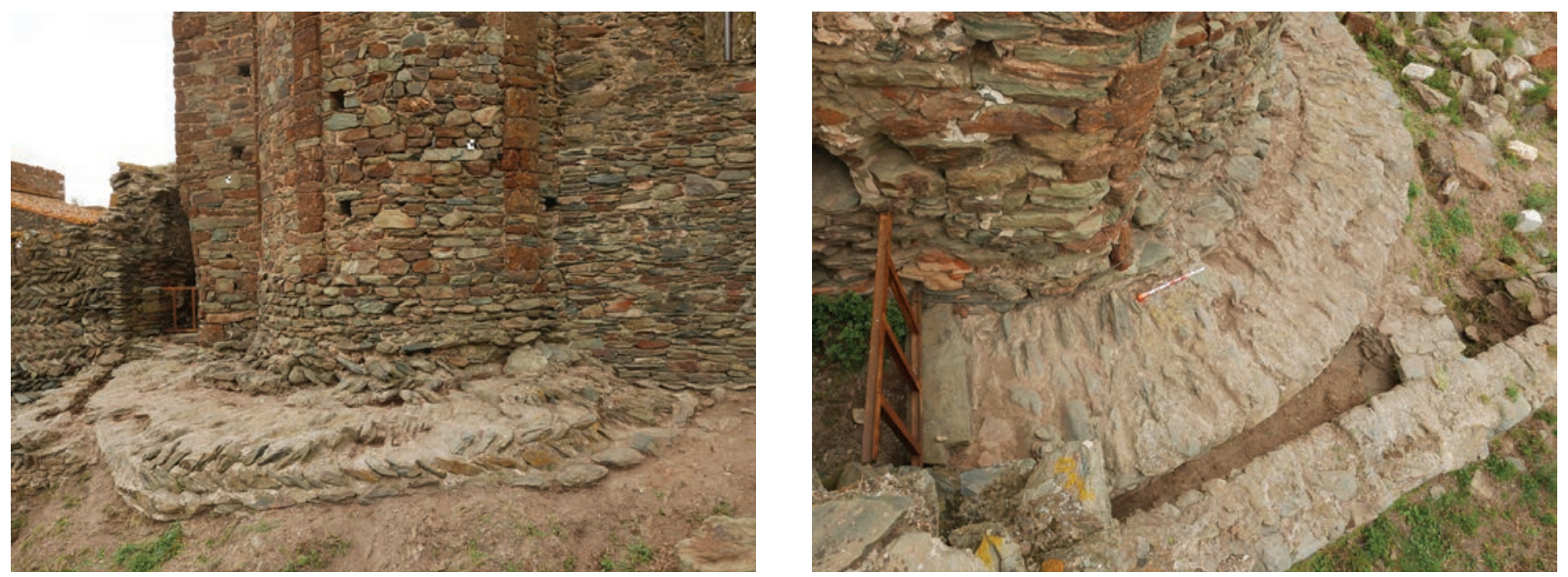

Fig. 16. Restos del hemiciclo conservado correspondiente a la cimentación de un primer edificio localizado en el ábside sur por el exterior.

A. Toma desde norte. B. Toma cenital desde sur (ECLOC/G. Ripoll).

ciar del primer edificio la pequeña habitación del claustro y a vincularlo tan sólo a los mencionados restos alrededor de la absidiola sur, de donde infiere una construcción más sencilla con un sólo ábside, probablemente de herradura, y aula rectangular, tal y como parece, en efecto, sugerir la prolongación en línea recta del semicírculo absidial, metiéndose en la iglesia románica por el lado septentrional y bordeando por el meridional el muro exterior del transepto. A esta iglesia sucedería asimismo la del abad Manuel, cuya cabecera tendría un único ábside coincidente esta vez con el central de época románica, altar elevado sobre una cripta semisubterránea que la autora identifica con los restos de mobiliario litúrgico que comentaremos más abajo, y un amplio transepto de 'dimensiones superiores al actual', del que tendríamos documentado el cierre oriental del brazo norte en los restos (aparentemente de un muro) que corren en dirección norte-sur frente a la embocadura de la absidiola septentrional de la iglesia románica.

Tras la inspección detallada de este conjunto de indicios, parece indudable que los vestigios conservados en la zona sudoriental se corresponden con el ábside de una iglesia anterior a la actual que debía abrirse a una nave rectangular del estilo de la que ha dibujado Codina. Más no se puede decir. El tramo de bóveda que se alza junto a la fachada del transepto meridional, apoyándose en ella, sería para Badia el resto de una bóveda anular que rodearía el ábside antiguo a modo de deambulatorio (como en Sant Pere de Rodes), pero dicho elemento está tan rehecho y maltrecho que nos es imposible refrendar su hipótesis. Lo mismo cabe decir respecto a la estancia que este autor identifica como absidiola sur. Al igual que las restantes estructuras de lado oriental del claustro, lo que ahí tenemos son los confusos vestigios de algunas dependencias claustrales repetidamente remozadas en época medieval y moderna, en especial durante el lago periodo en que el monasterio fue convertido en masía, del que da fe el epígrafe encastado en la propia fachada del transepto, bajo la ventana: "1867 FLORENCIO NOU VILAS”.

El mayor problema que se nos plantea no es tanto si el ábside primitivo estaba o no acompañado de dos capillas secundarias, sino más bien a qué iglesia (o iglesias) debemos atribuirlo. Tanto Badia como Codina consideran que pertenecía al edificio que podemos llamar 'fundacional' y dan por descontado que la iglesia consagrada con triple advocación en el año 935 fue una fábrica tanto o más grande que la actual que se comió enteramente o en grandísima medida la construcción anterior, suprimiendo el viejo ábside y erigiendo una nueva capilla mayor (acompañada o no de absidiolas) exactamente en el mismo lugar que ocupa la románica. Sin embargo, las evidencias materiales que ambos autores ofrecen de la existencia de este segundo edificio, por lo demás de un tamaño poco común, por no decir inédito, en el paisaje arquitectónico catalán del segundo cuarto del siglo X, nos parecen de escaso valor probatorio. No está nada claro que la hilada de piedras ligadas con mortero que corre en línea recta frente a la absidiola norte sea la banqueta de fundación de un verdadero muro, el de cierre oriental del transepto de la segunda iglesia, sino más bien un mero peldaño de acceso a dicha capilla (cuyo pavimento original, por desgracia, ha sido vaciado hasta dejar a la vista la roca madre) y coetáneo del entramado de gradas que observamos en el crucero y que sirvió para organizar las diversas formas de acceso al coro, y su subestructura, el bajo coro, románico de la capilla mayor (vid. más abajo). Es extraño, además, que de la supuesta construcción de los años treinta del siglo X no haya sobrevivido ni un solo indicio material más allá, como sostiene Badia, de los lienzos en espiga que se localizan de forma algo aleatoria en la mitad inferior de la fachada sur de la iglesia en casi todo su recorrido (desde el transepto hasta el cierre de la esquina sudoeste, hoy aislado y derruido al exterior, junto al refectorio) y en zonas muy concretas de la fachada norte de la nave, es decir, en buena parte de la caja de muros de la iglesia actual pero no en la cabecera y el transepto septentrional, como si de esta parte, y sobre todo de los ábsides -fuesen tres, como quiere Codina, o sólo el principal, como piensa Badia-, los constructores románicos no hubiesen podido reaprovechar ni un solo pedazo de muro o basamento, cosa rara en un edifico que se supone estaba levantando sobre el perímetro exacto del antiguo.

Una posibilidad que no parece haber sido contemplada es que el ábside primitivo, que es enorme (mayor, en cualquier caso, que el principal románico) (fig. 16), se reaprovechase íntegramente en la renovación del abad Manuel y que la intervención del prelado en el viejo monasterio se redujese a restaurar el aula o ciertas dependencias comunitarias. Ante la afirmación, en el acta de consagración de 935, de que Manuel destruyó "hasta los fundamentos las partes inútiles 


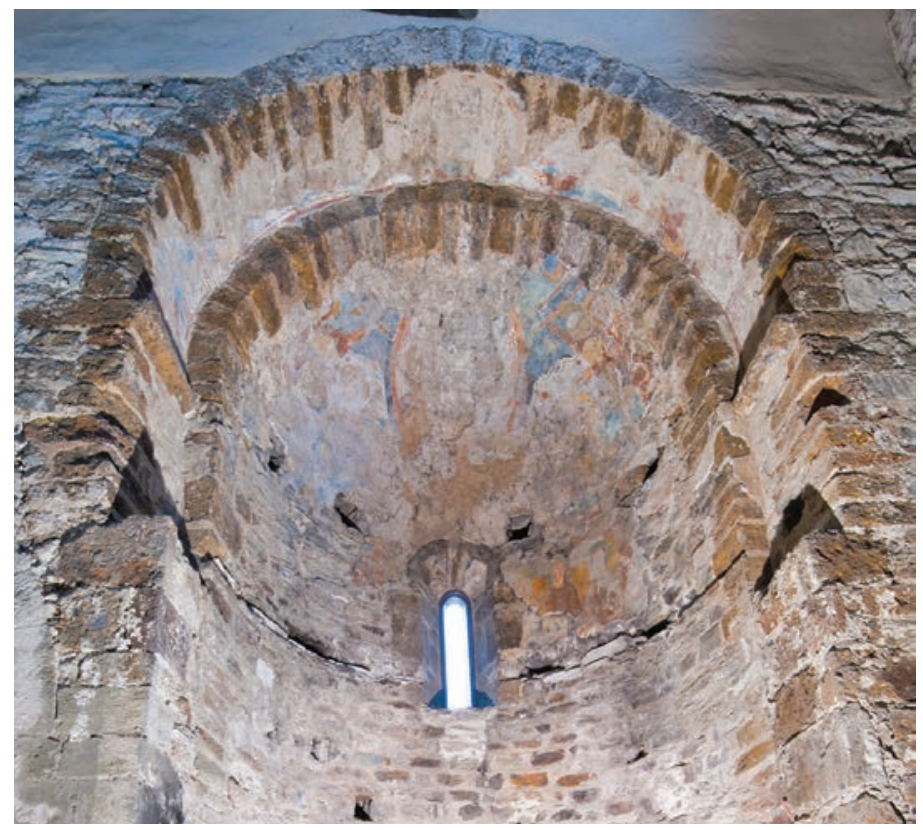

Fig. 17. Restos de la pintura mural conservados en la calota de la bóveda de la absidiola sur, primer tercio del siglo XII (ECLOC/LFA/D. Marcos).

del antiguo templo" y "reparó las obras todavía útiles", en la traducción de Badia ${ }^{48}$ (qui funditus ab eclesiis inutilia dejecit... caucibus et petris utilitas reformavit), los historiadores quizá han magnificado o sobrevalorado lo primero en detrimento de lo segundo, cuando el vacío de evidencias materiales con el que nos encontramos entre la construcción del ábside prerrománico y la elevación de la iglesia románica viene en realidad a sugerir que la parte reparada pudo haber sido bastante más extensa que la erigida a fundamentis. No olvidemos tampoco que la reconstrucción de la que nos informa el acta lo fue "de las iglesias -en plural-de san Quirce, san Andrés y san Benito" (ecclesiarum sancti Cirici sancti Andree et sancti Benedicti), término que naturalmente puede referirse a los altares, pero también a los distintos oratorios que a menudo conformaban los complejos monásticos y episcopales de la Alta Edad Media, con al menos una iglesia para la comunidad y otra para los parroquianos; bastará recordar, en el mismo siglo $\mathrm{X}$, la consagración conjunta en Ripoll (977) de la iglesia mayor dedicada a santa María y de la iglesia parroquial con doble advocación (san Pedro y san Andrés) situada en el propio cenobio ${ }^{49}$, o la dotación unos decenios antes (925) por el conde Suñer de Barcelona y en el mismo monasterio de una ecclesiam in honore Dei omnip[otentis et] Sancti Salvatoris cujus basilica sita est.... in cenobio Beate Marie, a lo mejor una iglesita independiente del santuario de Santa María cuyo titulus acabaría integrándose en ella a modo de altar secundario en la consagración de $977^{50}$. Tengamos finalmente en cuenta que la interpretación que acabamos de dar del documento de Sant Quirze, común en la historiografía, no es más que eso, una interpretación o traducción subjetiva. Nótese que la única obra realizada en piedra (caucibus et petris) a la que el acta alude consiste en la "reparación" (reformavit) -y no construcción de nueva planta- de la utilitas del viejo cenobio, sustantivo abstracto

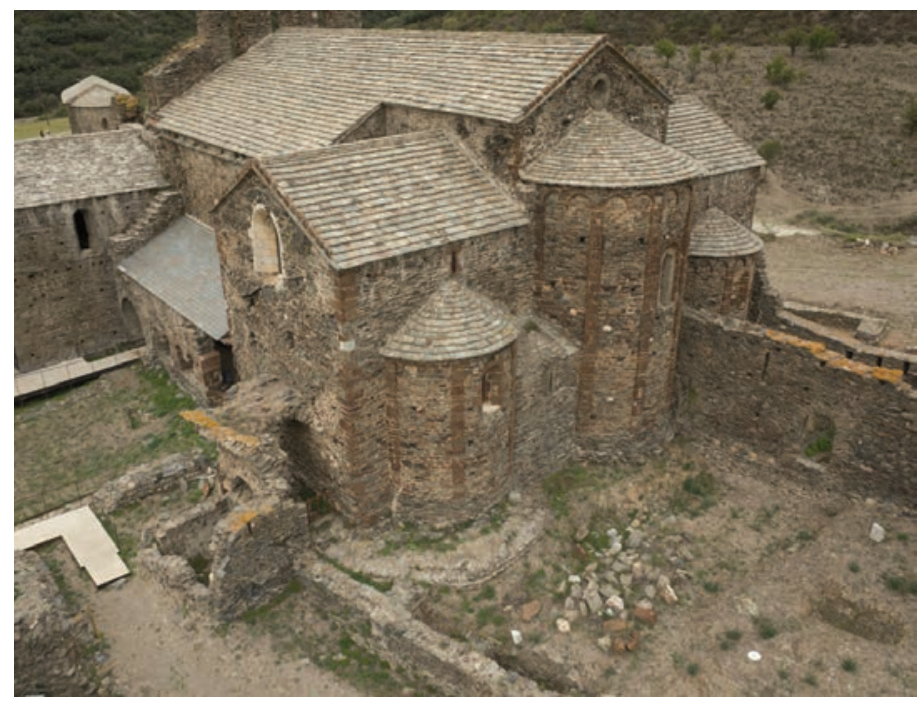

Fig. 18. Iglesia abacial. Cuerpo de fábrica desde el sudeste (ECLOC/LFA).

de tradición vitruviana que no tiene necesariamente por qué referirse a las partes "útiles", en el sentido de "aprovechables", del antiguo complejo, sino a sus construcciones de orden funcional, tales como conducciones de agua, cillas, etc.; y que las "cosas inútiles" (inutilia) que el abad sacó o "extirpó" (dejecit) de sus iglesias (ab eclesiis) no tuvieron por qué haber sido estructuras arquitectónicas, sino ornamentos anticuados (libros, cálices, etc.) o, mejor incluso, los pecados y miserias heredados de una etapa anterior de ruina económica y moral, entendiendo inutilia como "cosas dañinas" que, por lo demás, Manuel extirpó "de raíz" (fundamento).

Confiamos en que algunos de los interrogantes que acabamos de plantear podrán despejarse cuando finalicemos el estudio en profundidad que estamos realizando sobre el proceso constructivo de la iglesia románica, que entre otras cosas debería permitirnos explicar por qué el opus spicatum no parece haberse empleado ni en la cabecera ni en el brazo septentrional del transepto, así como el sentido de su azarosa presencia en el resto del edificio y en la galería y dependencias más antiguas del claustro. Una hipótesis a contemplar es que los dos tipos de paramento estén indicando dos fases constructivas de la propia iglesia románica y no la reformulación en el segundo cuarto del siglo XI de un edificio de hacia 935, como sostiene Badia. La existencia de una consagración en el año 1123 ha llevado a algunos autores a situar la edificación a caballo de los siglos XI y $\mathrm{XII}^{51} \mathrm{O}$ a vincularla directamente con tal fecha. Lo cierto es que con la consagración del obispo Berenguer Dalmau de Girona podrían estar perfectamente relacionados los restos de pintura mural hallados en la absidiola sur (fig. 17), dadas sus claras afinidades formales con conjuntos del primer tercio del siglo XII como los murales de Sant Martí de Fenollar y Santa María de la Clusa ${ }^{52}$, pero las líneas básicas de la arquitectura, tanto la estructura general del edificio como el aparejo de los muros, la morfología de las ventanas y los elementos decorativos de la cabecera (fundamentalmente, arcuaciones ciegas sobre semicolumnas rematadas por sencillos capiteles en el interior del ábside mayor y simples pero

$4^{8}$ J. BADIA I HOMS, op.cit. (n. 45), p. 161.

${ }^{49}$ R. ORDEIG I MATA, op. cit. (n. 3o), núm. 96, pp. 226-229.

${ }^{50}$ R. ORDEIG I MATA, op. cit. (n. 3o), núm., 46, pp. 115-116.

${ }^{51}$ Así D. CODINA, op.cit. (n. 6), pp. 39-63.

${ }^{52}$ Cf. M. PAGÈS, "La pintura mural romànica de Catalunya, avui", Catalan Historical Review, 6 (2013), 157-167 (pp. 160-161). 


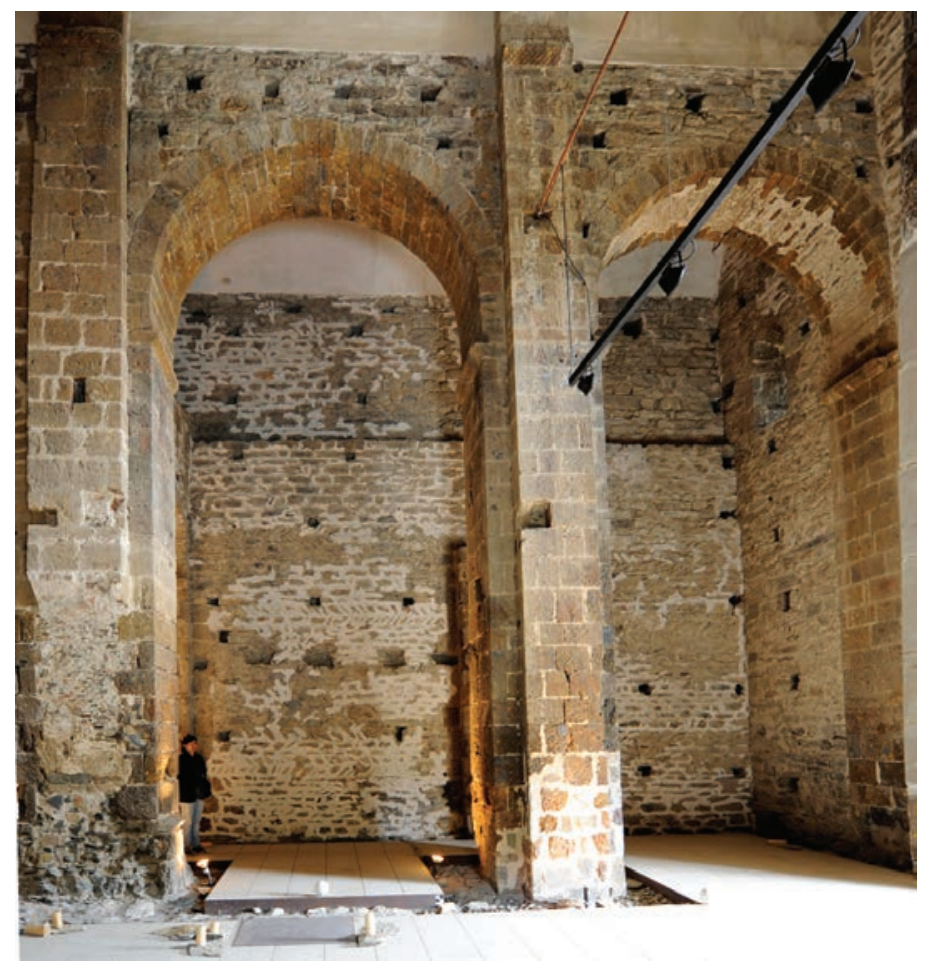

Fig. 19. Paramento interior sur de la nave de la iglesia abacial, tramo oeste (ECLOC/LFA).

variadas combinaciones de arquitos y bandas lombardas del exterior) nos llevan, sin lugar a dudas, a la primera mitad del siglo XI, a los tiempos en que se levantaba Sant Vicenç de Cardona (1019-1040) o, a lo sumo, como quiere Badia53, a un estadio intermedio entre ésta y Sant Miquel de Fluvià (1045-1066).

De todos modos, la iglesia románica es un edificio bastante más complejo de lo que parece a primera vista (fig. 18). En planta, con sus tres ábsides separados entre sí, transepto saliente ligeramente trapezoidal y tres naves de cuatro tra$\operatorname{mos}^{54}$, da la impresión de ser un proyecto unitario, lo que no quiere decir que en el curso de su materialización no se produjesen toda suerte de distracciones y pequeñas desviaciones del plan original como es característico -aunque pocas veces se tenga en cuenta- en toda la arquitectura del primer románico, siempre sujeta a cierto grado de improvisación y al principio del ensayo y error ${ }^{55}$. A ello obedece, por ejemplo, que el ábside meridional sea notoriamente más alto que el septentrional, como se observará comparando el nivel de arranque de sus respectivas ventanas (tanto las del hemiciclo como las que se abren en la bóveda del transepto) y, aún mejor, la altura de las claves de sus respectivos arcos triunfales. Y a dicho principio habrá que achacar también que la absidiola norte se halle cosida al cuerpo central del transepto, y no trabada o engarzada con él, lo cual justificaría asimismo la enigmática presencia a nivel de cimentación del muro anteriormente mencionado que delimita su embocadura en sentido norte-sur, construido acaso con función de tirante. Si bien es cierto que la cuestión no está resuelta puesto que el muro queda fuera de los pilares del arco del ábside y parece que la construcción de dicho ábside lo recorta.

Otra cosa son los graves problemas con los que los constructores se toparon en el momento de acometer la cubierta del edificio y que parecen estar en el origen, aquí sí, de un verdadero cambio de proyecto constructivo, fuese por iniciativa de los propios constructores románicos o bien posterior a su participación en la obra. En principio, por la ambición y cronología de la fábrica y por la disposición y morfología de los soportes de las naves (arcos doblados, potentes pilares cruciformes en la calle central y las correspondientes pilastras adosadas a los muros laterales) se diría que el proyecto preveía el abovedamiento integral del cuerpo del edificio, pero en éste se aprecian dos llamativas incoherencias que parecen indicar la frustración del plan inicial. Por un lado, los soportes interiores no se conjugan con contrafuertes exteriores y, por otro, los pilares adosados a la cara interior de la pared sur -que es la única de la que podemos fiarnos, dado que la norte acabaría hundiéndose prácticamente entera- están truncados a media altura; más aún, el propio muro está retranqueado aproximadamente al nivel de la línea de arranque de los arcos de separación de las naves (fig. 19). Si se pretendía abovedar las naves, que no se recurriese a los contrafuertes exteriores, máxime en una iglesia de considerable altura y situada para más riesgo en una ladera, causa verdadera perplejidad, pero en los estadios experimentales del románico todo es posible (tampoco la nave del transepto los tieney, a primera vista, su abovedamiento se diría que iba incluido en el proyecto original). Como sea, los constructores debieron percatarse del error cuando la elevación de las naves se hallaba ya al nivel de arranque de los arcos torales y se vieron obligados a renunciar al cubrimiento abovedado y a sustituirlo por una armadura de madera provisional. Y decimos "provisional" porque todo viene a indicar que las bóvedas que hoy vemos son románicas, lo que quiere decir que la idea del abovedamiento volvió a retomarse decenios después, seguramente por otra cuadrilla de canteros que sería la que decidiría situar la línea de arranque de las bóvedas colaterales a su altura actual, bastantes metros por encima del nivel previsto por sus predecesores (que es el que señalan la pilastras truncadas del colateral meridional y el retranqueo del muro un poco más arriba). En el cimacio del pilar meridional en el que apea el arco fajón occidental y en el oriental del segundo arco toral del mismo lado observamos un detalle interesante: a diferencia de las restantes impostas del edificio, estos dos presentan un motivo de ajedrezado (fig. 20) cuya repentina (y explosiva) aparición en el románico europeo no es anterior, como se sabe, a 1070 ${ }^{56}$. Desconocemos cuál pudo ser la cronología de su introducción en tierras catalanas, pero en cualquier caso no parece anterior a 110o, fehaciente post quem del cambio de proyecto, lo que podría llevarnos de nuevo -con las pinturas de la absidiola

\footnotetext{
53 J. BADIA I HOMS, op.cit. (n. 45).

${ }^{54}$ No de tres, como supone J. BADIA I HOMS (Catalunya Romànica IX, II, p. 767, cf. n. 27) al atribuir el tramo más occidental a la iglesia del abad Manuel y la elevación de la fachada actual a la románica del siglo XI. Como señala D. CODINA, op.cit. (n. 6), p. 20: "la rasa de construcció d’aquest nou mur talla estrats que presenten restes ceràmiques datades del segle XIV".

55 Sobre la naturaleza experimental del primer románico, véase D. RICO, "La arquitectura románica: originalidad y génesis", in M. CASAS (ed.), La catedral de Salamanca. De fortis a magna (Salamanca, 2014), pp. 215-232.

${ }^{56}$ Cf. I. SGRIGNA, Los repertorios decorativos en la escultura medieval: el ajedrezado como instrumento para la definición de una geografía artística en el marco del románico europeo (Tesis doctoral inédita) (Barcelona: Departament d'Història de l'Art, Universitat de Barcelona, 2010).
} 

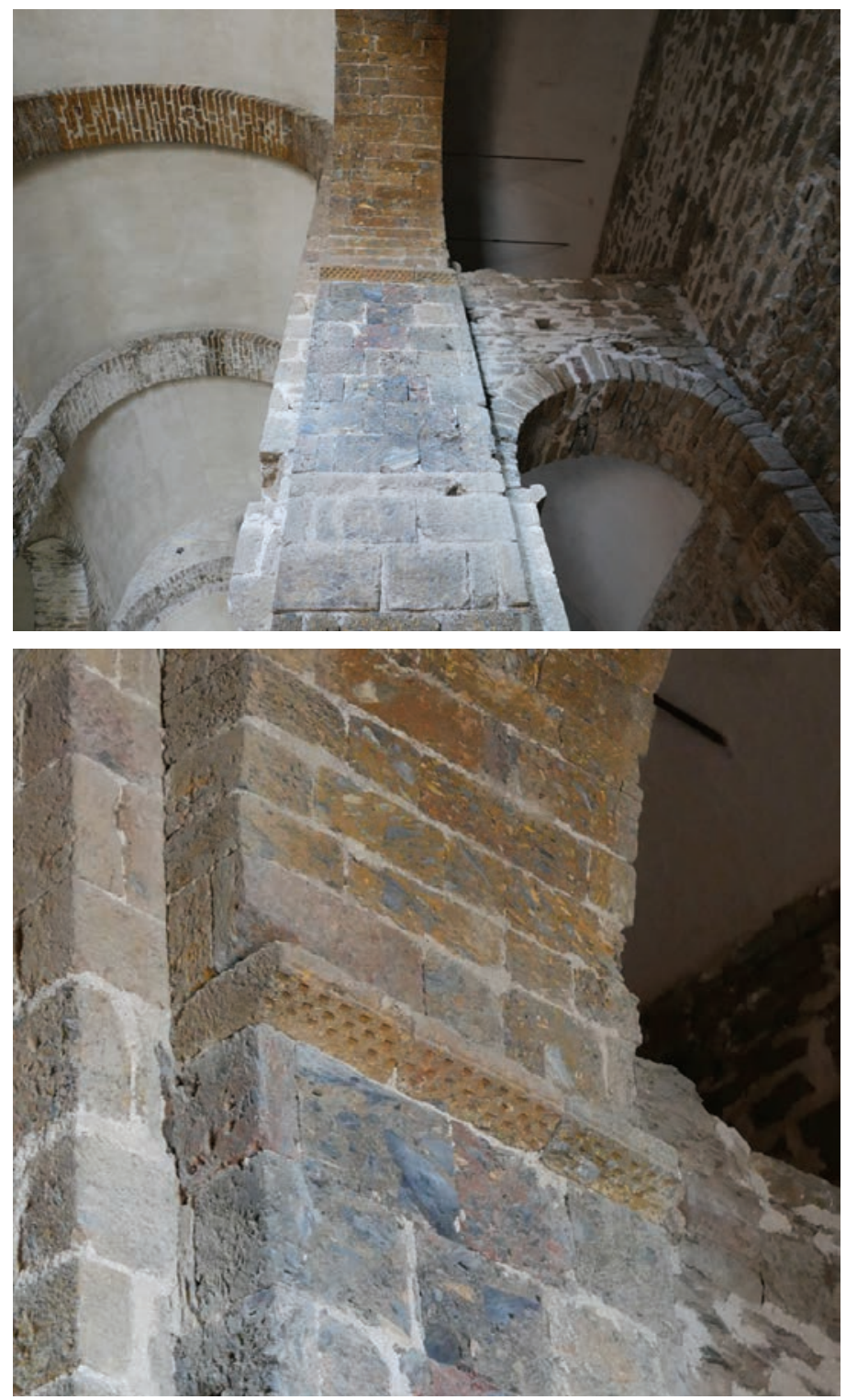

Fig. 20. Elemento decorativo de ajedrezado o damero. A, Posición de la imposta en el pilar cruciforme de la nave sur; se visualiza también la cubierta de la nave central y la lateral. B, Detalle del elemento decorativo (ECLOC/G. Ripoll).

meridional- hasta la consagración de 1123. Luego llegaría igualmente la aparatosa ruina del tramo occidental y buena parte del colateral septentrional, ocasionada precisamente por la desastrosa decisión, por parte del segundo taller, de llevar el arranque de las bóvedas de las naves laterales respecto a la altura prevista por el primer taller y dejarlas así al mismo nivel que el cañón de la nave central, haciendo una especie de Hallenkirche avant la lettre que no resistió el paso del tiempo. Paradojas de la vida: si las hubieran colocado a la altura prevista por sus predecesores, habrían funcionado como contrarrestos de la enorme nave central y ésta se habría aligerado con unas ventanas que, además, habrían contribuido a iluminar la iglesia. Uno o dos siglos después del derrumbe vino la restauración, que, además de construir la fachada actual robándole un tramo a la iglesia original, trató de afianzar la estructura románica elevando dos habitaciones de refuerzo a modo de tribunas sobre el tramo oriental de las naves laterales.

De la etapa románica cabe destacar, por último, la elevación de la zona de la capilla mayor, debido a la organización de la zona mediante su mobiliario litúrgico original (fig. 21). Durante las excavaciones en la iglesia realizadas por D. Codina, bajo el solado frontero a la capilla mayor y correspondiente con la superficie del transepto, aparecieron los restos de una suerte de plataforma con forma trapezoidal, más estrecha hacia la zona del ábside y más ancha hacia el tramo de crucero. En la zona frontal, hacia la nave, quedaban los restos de dos entradas laterales, accesos que también aparecían en los costados norte y sur (este último menos definido), incluso con restos de gradas o peldaños sobre un solado original de mortero de cal. Dicha autora no dudó en identificar estas estructuras con los vestigios de una cripta. La justificación funcional de dicho elemento la buscó en paralelos carolingios que no refirió, en la monumentalización de las cabeceras a partir de los siglos IX y X, y en un posible culto a santos a partir de las reliquias que existieran en el monasterio. El conjunto de la supuesta cripta fue datado por dicha autora en el siglo $\mathrm{X}^{57}$. Como decíamos, en realidad nos encontramos ante los restos de una estructura coral, por tanto, muy posterior a la cronología aportada, coetánea de la fábrica románica y que nada tiene que ver con la iglesia previa. Un análisis detallado del asunto, en consonancia con el edificio conservado, nos servirá como explicación. En los tiempos en que se construyó la iglesia de Sant Quirze de Colera, una de las localizaciones habituales del coro era el presbiterio, generalmente sobreelevado en una plataforma sobre columnas, que se proyectaba sobre el tramo de crucero en una superficie variable ${ }^{5}$. Esto, en ocasiones, condicionaba la proyección en altura del ábside principal, con el fin de albergar esta subdivisión en alturas. En Sant Quirze, el ábside hoy nos muestra una superficie organizada en dos, con un piso bajo marcado por el arranque de los restos de una bóveda y, encima, el paramento articulado mediante largas columnas y arcos ciegos desde los que arranca la bóveda de horno. Los restos de la estructura hallada en el solado del tramo de crucero y esta subdivisión del ábside en altura están claramente vinculados, al tratarse de parte de un mismo proyecto: una plataforma coral que subdividía en altura la capilla mayor, asentada sobre una estructura de fábrica con sus respectivas entradas frontales y laterales. El acceso lateral norte en el transepto es evidente, el lateral sur probable y los frontales difíciles de determinar por la falta de información directa. En todo caso se trataba claramente del sotocoro, un espacio con un nivel de suelo algo más bajo que el resto de la iglesia, pero cerrado por la estructura abovedada que sustentaba el coroy no por hallarse por debajo de la cota cero. No en vano, este tipo de solución existió en otros lugares como las catedrales de Vic y Jaca, y se conserva en la de Roda de Isábena o en los monasterios de Santa María de Alaón y Sant Llorenç prop Bagà. En Vic, la estructura sobresalía de la capilla mayor, ampliándose

57 D. CODINA, op.cit. (n. 6), pp. 47-49. Los restos incluso han llegado a interpretarse como los de una iglesia previa a la actual: G. BOTO, “Topografía de los monasterios de la marca de Hispania (ca. 80o-ca. 1030)", in A. GONZÁLEZ DE CORTÁZAR y R. TEJA (coords.), Monjes y monasterios hispanos en la Alta Edad Media (Aguilar de Campoo, 2006), pp. 147-204.

${ }^{8}$ Una visión de conjunto sobre el problema en E. CARRERO, "Centro y periferia en la ordenación de espacios litúrgicos. Las estructuras corales", Hortus Artium Medievalium, 14 (2008), 159-178 e ID., "Entre el transepto, el púlpito y el coro. El espacio celebrativo de la Sibila”, in M. GÓMEZ y E. CARRERO (coords.), La Sibila. Sonido. Imagen. Liturgia. Escena (Madrid, 2015), pp. 207-26o. 


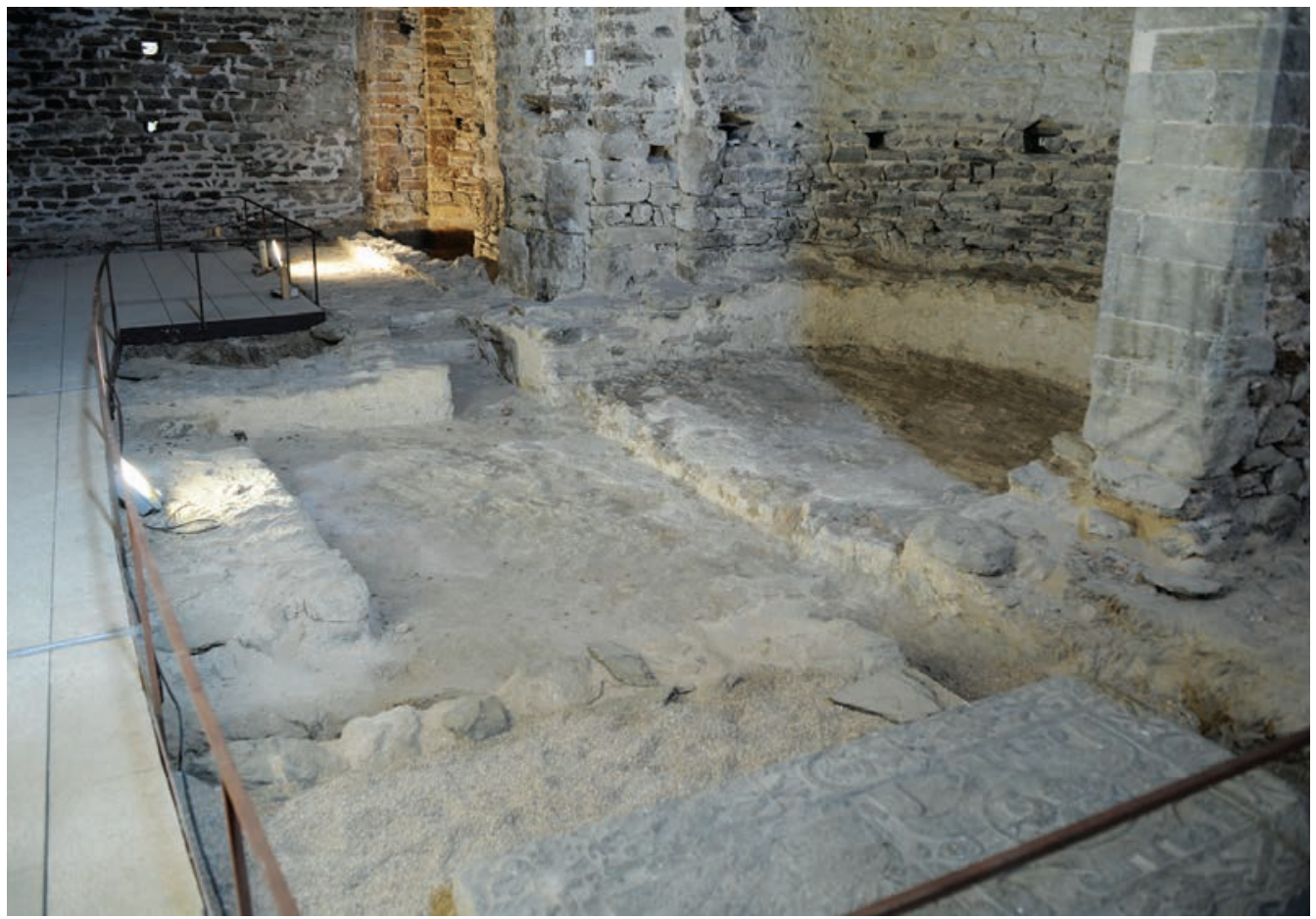

Fig. 21. Ábside mayor y centro del transepto con las estructuras visibles para sustentar las estructuras del coro alzado (ECLOC/LFA/D. Marcos)

después a toda la superficie del tramo de crucero. Aquí, el piso bajo incluso tuvo funciones litúrgicas albergando un altar propio, con sus funciones claramente diferenciadas en el discurrir litúrgico de la catedral59. En Jaca, la misma estructura fue derruida en el siglo XVI. En la capilla mayor y bajo el crucero, el coro estuvo sobre unas columnas que recibieron enterramientos y epígrafes funerarios hasta su desaparición. Debió ser algo más monumental que la que todavía hoy podemos contemplar en Roda de Isábena, cuyo piso bajo fue aprovechado para situar el sepulcro con los restos del obispo santo Ramón ${ }^{60}$. Muy posiblemente, la plataforma coral de Sant Quirze de Colera tuvo en el frente del bajo coro o sotocoro, un altar, duplicado del mayor que se ubicaba entre la sillería de los monjes en el piso alto. Así se puede ver aún en viejos dibujos representando la organización litúrgica de la excatedral de Roda de Isábena, previa a las restauraciones contemporáneas ${ }^{61}$.

¿Cuándo se suprimió la estructura coral del presbiterio de Sant Quirze de Colera? De nuevo la excavación arqueológica nos aporta algunas claves. En la intervención realizada por D. Codina, aparecieron los restos de unos muros de cierre entre las naves, correspondientes a los tramos centrales de la iglesia, y que corren por la cara interna de sus soportes y cerrando transversalmente entre los soportes más cercanos a los pies. Si se ha querido relacionar con la descrita estructura del altar mayor, para interpretarlos como los muros de una iglesia anterior que cerraba así hacia occidente, en realidad se trata de los vestigios de los muros perimetrales de un coro situado en la nave, esto es, un trascoro. Por un lado, su limitado grosor simplemente aconseja cautela a la hora de plantearlos como restos de un edificio. Por el otro, están claramente apoyados sobre la cimentación de los soportes de la iglesia, revelando su posterioridad a la misma. Por último, si levantamos la mirada del suelo, encontraremos que los soportes de la iglesia de Sant Quirze de Colera fueron afeitados a cierta altura con la intención de instalar los espaldares de una sillería de coro que, precisamente, se corresponde con los restos de lo que ahora explicamos como el trascoro. Volviendo a la sillería en la estructura elevada de la cabecera, que describíamos líneas atrás, es difícil establecer cuándo fue suprimida. La iglesia monástica siguió una evolución espacial modélica que nos lleva al final de la Edad Media o comienzos de la moderna. Si en Roda, ya reubicada la dignidad episcopal en Lleida, el coro se mantuvo en la cabecera, en las catedrales de Vic y Jaca, fue desmontado en los siglos XV y XVI, respectivamente, trasladándose en ambos casos a la nave, aportando una nueva perspectiva visual del presbiterio. Pero esto ocurrió en dos catedrales. En monasterios benedictinos, como el que nos ocupa, el itinerario del coro también pudo ir desde la capilla mayor a los tramos más occidentales, aunque lo más habitual fue la elevación de un coro a los pies entre los siglos XV y XVI, pero preservándose también el coro de la cabecera, como sabemos que ocurrió en Ripoll, en Silos, o aún se conserva en la iglesia nueva de San Millán la Cogolla. En los restos del monasterio de Alaón hallamos otro ejemplo muy semejante: la elevación del presbiterio sobre unas gradas y cripta y el cierre de coro mediante los restos de un engatillado aún visible que, después, fue trasladado a los pies de la iglesia, dejando las huellas del mismo. En este caso, la posición de un púlpito moderno en uno de los soportes donde aún hay restos del engatillado de cierre quizás esté marcando el momento en el que se realizó la sillería de los pies de la iglesia. En nuestro caso, en Sant Quirze de Colera, parece que el recorrido del coro fue de la capilla mayor a la nave, sin que debamos desestimar la posibilidad de que parte de una sillería quedara aún instalada en la capilla mayor que, de hecho, parece un espacio que no ha sufrido una alteración en clave renacentista o barroca desde la supresión de la estructura coral (fig. 22).

Además de los cambios de las instalaciones litúrgicas, la cabecera de la iglesia sufrió una notable alteración con la apertura de una capilla moderna entre los ábsides central y meridional. Se abrió en el grosor del paramento que separaba ambos ábsides, sobresaliendo hacia el exterior. Fue una capilla en arcosolio cubierta por bóveda de cañón apuntado,

59 E. CARRERO, op. cit. (n. 58), y, de forma monográfica, el documentado trabajo de M. SUREDA JUBANY, “Clero, espacios y liturgia en la catedral de Vic: La iglesia de Sant Pere en los siglos XII y XIII", Medievalia, 17 (2014), 279-320.

${ }^{60}$ G. FERNÁNDEZ SOMOZA, “Arquitectura y liturgia en la Catedral de Jaca. Coro, claustro, reliquias y urbanismo”, in E. CARRERO (coord.), Arquitectura y liturgia. El contexto artístico de las consuetas catedralicias en la Corona de Aragón (Palma de Mallorca, 2014), pp. 57-74.

${ }^{61}$ I. LORÉS I OTZET, "Hagiography and Memory: The Use of Bishop Saint Ramon of Roda in the Thirteenth Century”, Hortus Artium Medievalium, 21 (2015), 136-151. 


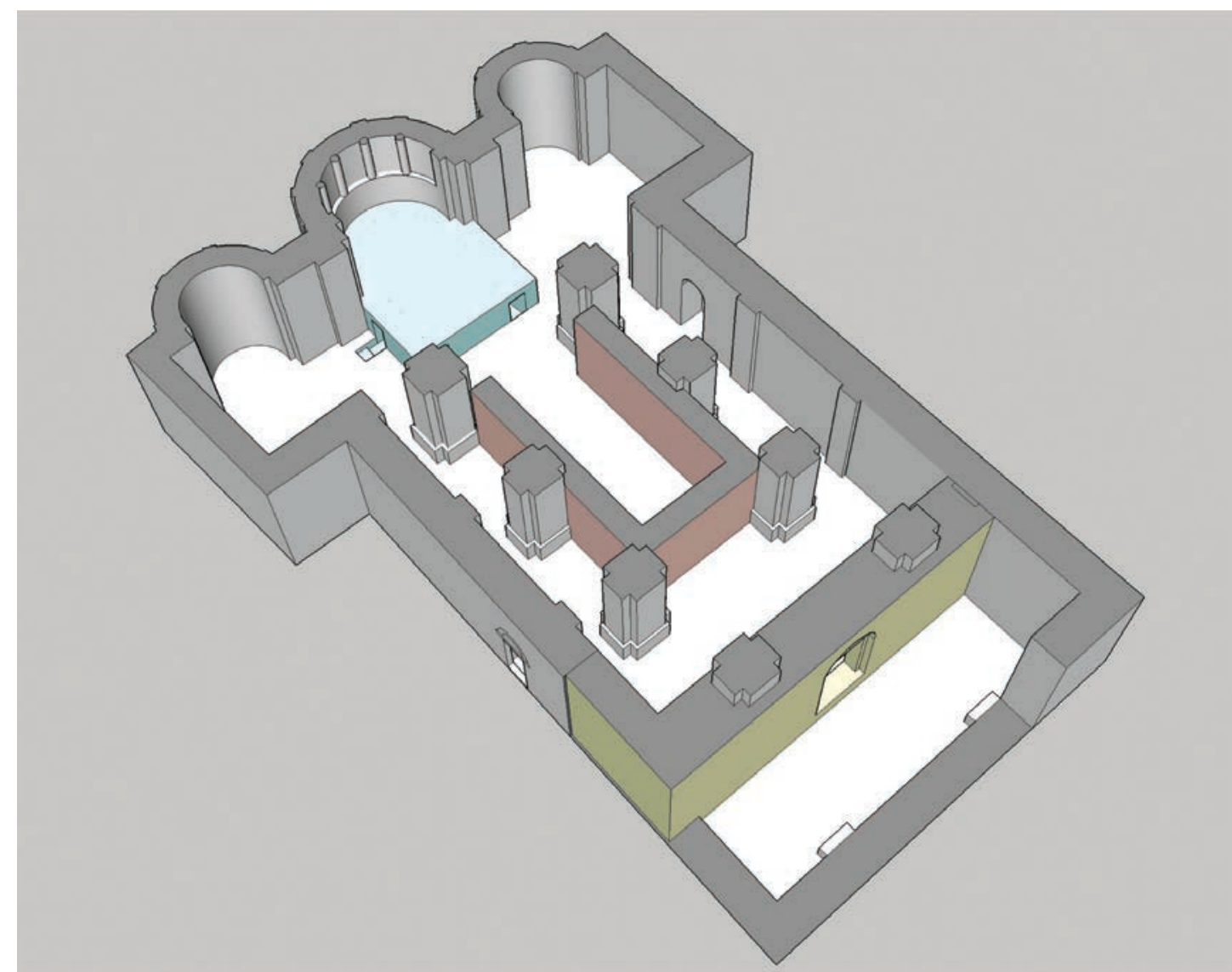

Fig. 22. Hipótesis de restitución de las estructuras corales. El primer coro ubicado en el ábside central y la zona medial del transepto. El posterior trascoro en la nave central (ECLOC/J. Benseny, F. Tuset, E. Carrero, D. Rico y G. Ripoll).

sobre dos mochetas, que aún hoy conserva remanentes de enfoscado. Se utilizó como mausoleo funerario de los Maillol cuando la familia recibió en 1598 el monasterio por enfiteusis concedido por el abad de Besalú, Francesc Gavarrer. Es en esta capilla donde estaba ubicada la lápida funeraria de 1622 (hoy en el suelo del transepto) y el retablo pétreo llamado de la "Mare de Déu del Bon Any”, fechado en 1625y trasladado a la iglesia de Sant Quirc y Santa Julita en $1795^{62}$, muy cerca del Mas de Sant Quirze (antiguo Mas Maillol/Nouvilas), a 3 km al sudoeste del conjunto monástico. A esta misma iglesia se había trasladado, no sabemos si desde la iglesia monástica o la de Santa María, la pila bautismal bajo medieval ( $\varnothing 110$ $\mathrm{cm}$, altura $93+18 \mathrm{~cm}$ ), que finalmente retornó al monasterio en 2012. Es importante señalar que la capilla abierta entre el ábside central y el ábside sur sirvió como paso de carruajes en el momento de la transformación de la iglesia en dependencias de almacenaje de la vecina explotación agrícola, con lo que ello comportó a nivel de degradación de todo el conjunto eclesiástico.

\section{Claustro}

El claustro se dispuso junto al costado meridional de la iglesia, con la que se comunica mediante una portada en arco de medio punto con un desarrollado dovelaje. De la estructura original del claustro conservamos parte del trazado de sus pandas, sacado a la luz en las excavaciones arqueológicas, y un fragmento de la galería norte, fosilizado al utilizarse a modo de pórtico adosado a la fachada sur de la iglesia (fig. 23). Se trata de cuatro arcos separados por un grueso machón y sus arcos de comunicación con las vecinas galerías oeste y este. Según delatan fotos de comienzos del siglo XX, los arcos estuvieron macizados hasta las primeras intervenciones restauradoras en el conjunto, hecho que debió favorecer su conservación. Llama la atención poderosamente la articulación irregular del perímetro del claustro, hecho habitual en otros monasterios cronológicamente próximos a Sant Quirze, como los vestigios del de Sant Miquel de Cruilles.

$\mathrm{Al}$ este de la galería oriental, frente al brazo sur del transepto, se conservan algunas de las estructuras más intrigantes de todo el conjunto. Se trata de una serie de paramentos que parecen componer cuatro estancias. La más estrecha y rectangular dotada de bóveda de cañón fue identificada por Joan Badia como capilla lateral de la iglesia más antigua. A nuestro juicio, al menos tres de los cuatro ámbitos son dependencias u oficinas comunitarias, la mayor de las cuales, vecina de la galería claustral, debería corresponder a la sala capitular, dado que su posición es la canónica en casi todos los monasterios de tradición benedictina (fig. 24).

Entre los elementos medievales que antiguamente se hallaban en el claustro se cuentan dos relieves funerarios (cf. infra). El más antiguo, considerado románico por los estudiosos que lo han catalogado, representa una procesión con un obispo u abad portando un báculo, acompañado de dos ministros que sostienen el gremial. El segundo es una pieza gótica en la que se esculpió el lecho del difunto abad Berenguer de Vilatenim (1320). Ambos elementos se hallan hoy depositados en la casa del antiguo propietario. Material

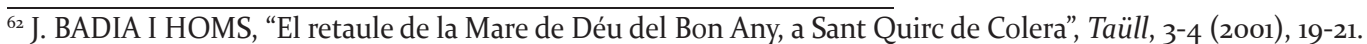




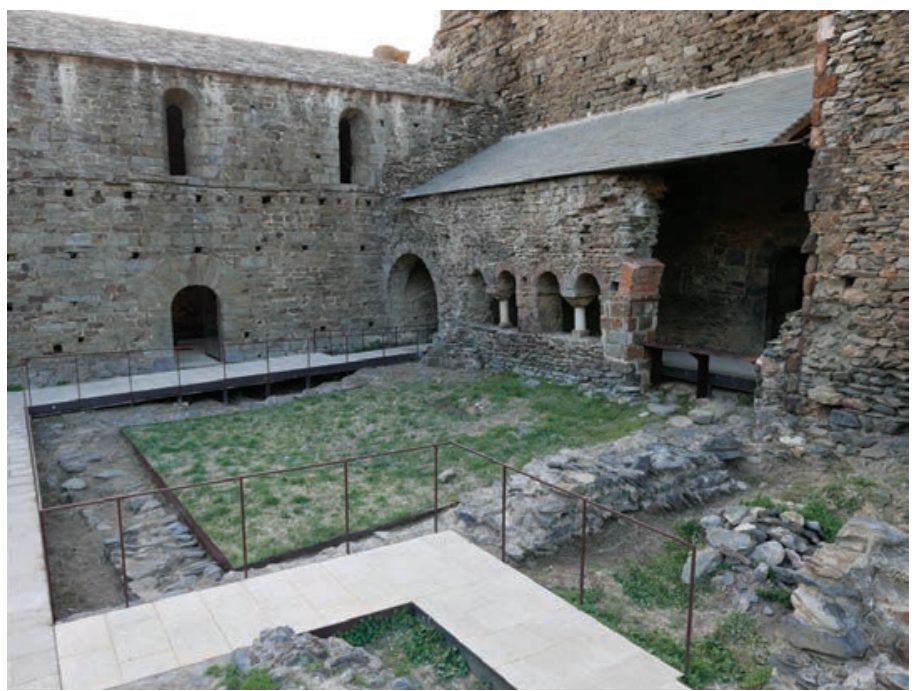

Fig. 23. Estado actual del claustro tras las excavaciones y obras de restauración $y$ adecuación de finales del siglo XX (ECLOC/G. Ripoll).

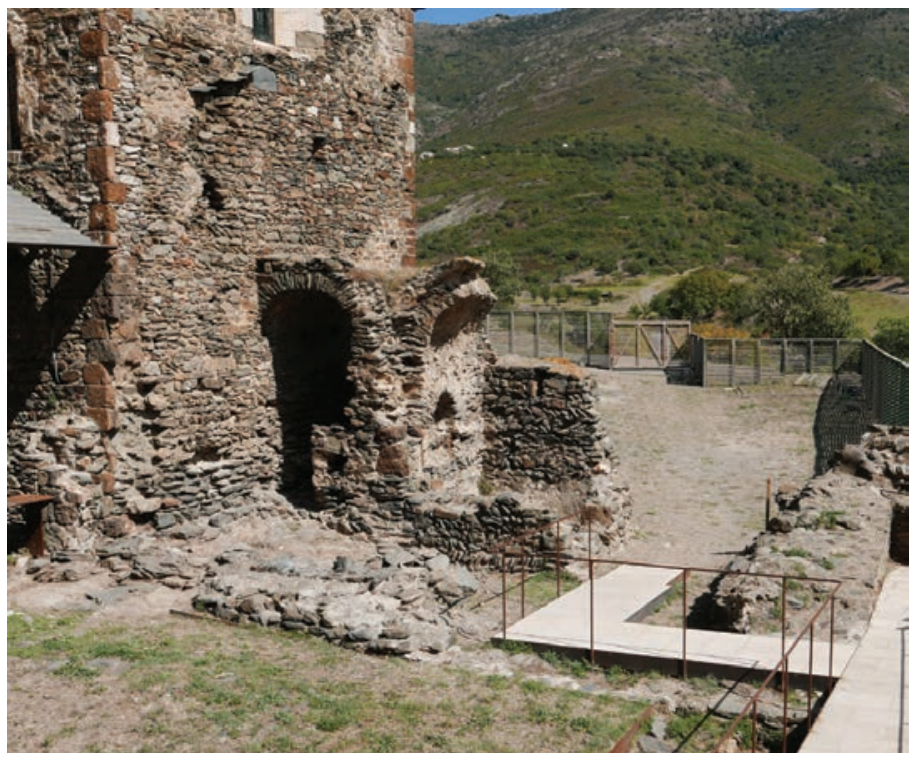

Fig. 24. Dependencias comunitarias y sala capitular al este del claustro (ECLOC/G. Ripoll).

escultórico que se suma a los capiteles, tal como se verá más adelante.

Es importante resaltar que las excavaciones de $1997 \mathrm{pu}-$ sieron a la luz una amplia necrópolis en toda la superficie ocupada por el conjunto monástico, particularmente densa en la zona del claustro, refectorio y fachada occidental de la iglesia monástica.

\section{Refectorio}

El tercer bloque constructivo de cierta importancia es el integrado por el refectorio, que se ubica al oeste del conjunto claustral, en una posición anómala dentro del patrón monástico benedictino, que se suele localizar en el ala opuesta a la de la iglesia. Se trata de una estructura rectangular de 13,75m de longitud por 5,64m de anchura que ocupa toda la superficie vecina a la galería y que se eleva sobre potentes muros. En origen estuvo cubierta con bóveda de cañón apuntado sobre arcos fajones e iluminada con dos series de ventanas en sus paramentos este y oeste. La bóveda, que aún conserva restos de revoco con un pincelado en ocre sobre fondo blanco, es obra tardomedieval, y su vertiente

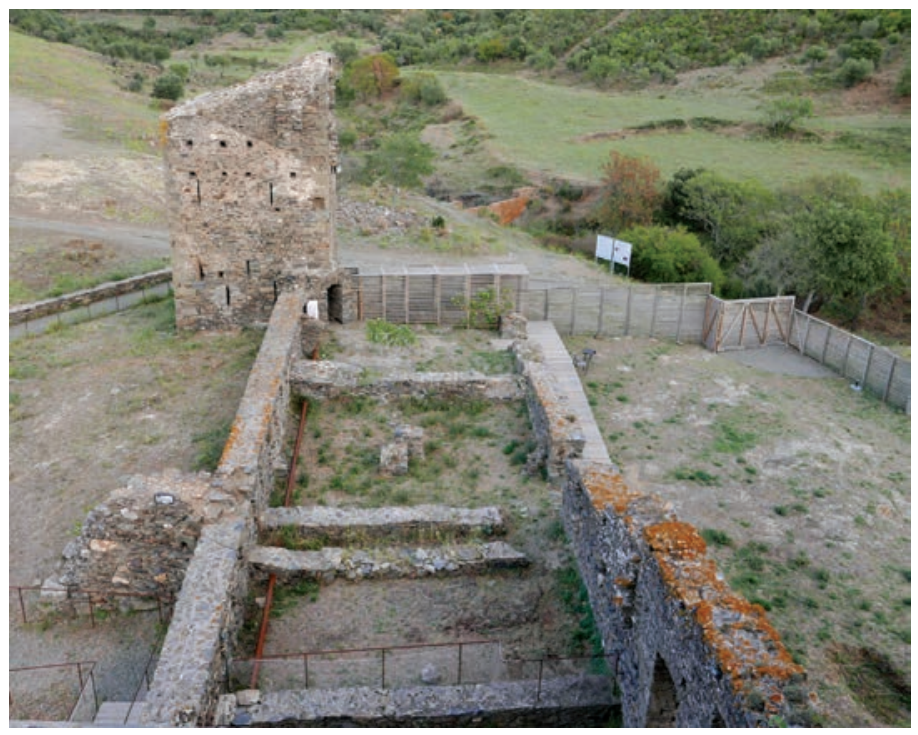

Fig. 25. Edificios situados al este del conjunto monástico rematados por una torre de planta cuadrangular (ECLOC/J. Tuset).

meridional se vino abajo tras el abandono del monasterio a finales del siglo XVI.

Bajo el edificio actual, las excavaciones pudieron reconocer la estructura original del refectorio primigenio y quizás una cocina, hoy visibles bajo el forjado que hace las funciones de solado, además de una gran necrópolis de sepulturas antropomorfas excavadas en la roca que tiene continuidad bajo la fachada oeste de la iglesia monástica y en toda la superficie ocupada por el claustro, tal como ya se ha dicho. La relación entre los individuos ahí enterrados y los restos estructurales de un primer refectorio es algo que requiere ser profundizado y necesita establecer las correctas relaciones crono-estratigráficas.

\section{Edificio anejo al este y torre}

La cuarta estructura que compone el conjunto monástico es el edificio que se extiende hacia el este desde el transepto norte de la iglesia (de $28 \mathrm{~m}$ de longitud y 9,49m de anchura), con una torre en su extremo oriental, de planta cuadrada de $5,84 \mathrm{~m}$ de lado (fig. 25). Se trata de una obra que se asienta sobre un profundo desnivel de terreno hacia el lado septentrional del conjunto construida sobre la roca natural, toda ella repiqueteada. Conserva únicamente la caja de muros y hasta tres subdivisiones internas, y ha sido relacionada con una obra de defensa o fortificación del conjunto monástico de finales del siglo XIII debida a la presencia de tropas, tanto francesas como de Jaume II de Mallorca. Algunos de los fosos del conjunto, especialmente el situado al este de la cabecera de la iglesia es posible sean de esa cronología, sin embargo la crujía ha de ser anterior a este momento. La localización, morfología y secuencia estratigráfica del edificio rectangular subdividido en espacios permite pensar que se trata tan sólo de una ampliación de la clausura rematada por una torre que tiene su pareja en el ángulo opuesto, al sur y que no ha sido excavada. Es decir, un segundo patio de servicios, adosado con posterioridad a la iglesia abacial y encastillado, como es común en toda la arquitectura monástica de la época.

\section{Residencia abacial}

Por fin, en la galería meridional del claustro se hallan los restos de lo que parece ser un núcleo residencial, habitual- 
mente identificado con el palacio abacial. Se trata de una de las zonas más arruinadas del conjunto, compuesta por un edificio de distintas alturas que se dispone sobre bodegas cubiertas con bóveda de cañón en su parte baja, todo ello condicionado por un notable desnivel de terreno respecto del resto del monasterio. La degradación de las estructuras es muy grande porque es donde se construyó la casa de los caseros de la masía moderna y donde no ha habido ninguna intervención de restauración.

\section{Iglesia de Santa María}

La parroquia del lugar vinculada al monasterio se dedicó a santa María. Se trata de una sencilla fábrica de una sola nave y ábside articulados mediante arco triunfal doblado. La cabecera está cubierta con bóveda de cuarto de cañón y la nave es de cañón apuntado (fig. 26). Las dimensiones del edificio son: long. ext. 16,68m; long. int. 14,9om; anch. ext. 8,44m; anch. int. 5,58m; la altura de la nave es de 7,68m y la del ábside de $6,44 \mathrm{~m}$.

El estudio murario de la iglesia es extremadamente dificultoso debido al derrumbe que sufrió la zona sudoeste y la consiguiente reconstrucción. En cualquier caso, podemos destacar que predomina el uso puntual de grandes sillares bien escuadrados en algunas zonas, en tanto que en otras se combina con sillarejo y ladrillos con aglutinante de mortero de cal. Además, hacia el interior hallamos dos líneas superpuestas de mechinales, una a aproximadamente un metro y medio de altura y la segunda previa al arranque del abovedamiento. En clara diferencia de materiales respecto a los muros, la bóveda de la nave está realizada mediante delgadas piedras puestas de canto que, con una sutura entre la primera y segunda ventanas comenzando desde la cabecera, muestran al menos dos tramos de realización. La fachada septentrional carece de huecos de iluminación con el objeto de proteger la iglesia del potente viento de tramontana que suele afectar a la región, mientras que en el muro meridional se abren tres ventanas, además de la puerta de acceso, y en el occidental otra ventana suplementaria. En todos los casos se trata de arcos de medio punto que, si en las ventanas adquieren forma de aspilleras, en la puerta se organiza mediante un tímpano hoy carente de decoración pero que, en origen, pudo tener escultura o pintura. En la cabecera, el ábside se ilumina mediante una única ventana con arco de medio punto y potente dovelaje, quizá ampliada en una intervención tardía.

En el interior, parece que el cuarto de cañón del ábside y la bóveda de la nave pertenecen a dos fases diferentes, habiéndose volteado la segunda en fechas más tardías, como corresponde a su perfil apuntado, en correspondencia con el desarrollo en altura del arco triunfal. El suelo del edificio ha sido excavado hasta el nivel de la roca madre y todo el muro perimetral de la iglesia se halla rodeado por un banco de piedra, vinculado seguramente al uso parroquial del edificio.

\section{Escultura y epigrafía}

Dentro del proyecto de análisis global del conjunto arquitectónico de Sant Quirze de Colera es necesario incluir la escultura y la epigrafía de la que se tiene noticia, iniciando el estudio por la producción de un material gráfico de alta cualidad que permita el posterior análisis sin la necesidad de manipulación de las piezas. Las posibilidades que hoy en
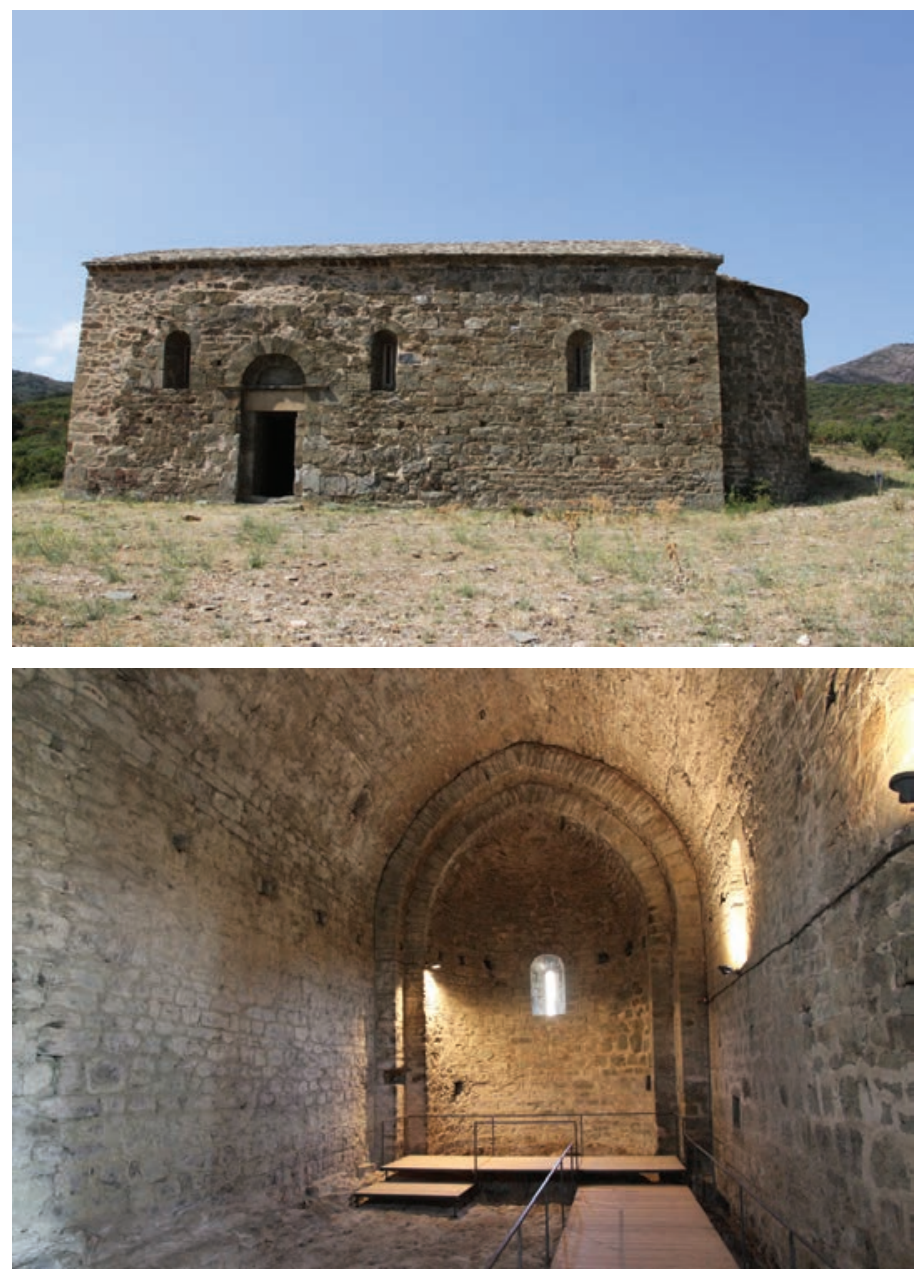

Fig. 26. Iglesia parroquial de Santa María. A, Exterior sur. B, Interior (ECLOC/N. Olivé).

día ofrecen las nuevas tecnologías permiten obtener unos resultados extremadamente útiles para los investigadores a la vez que utilizable para la creación de material divulgativo dirigido a todo tipo de público.

El conjunto monástico, tal como se ha dicho precedentemente, entró en decadencia en el siglo XV y en 1836 se produjeron su desamortización y casi inmediata exclaustración. Esta situación favoreció el expolio, llegando hasta nuestros días escasas piezas relevantes. Una lauda funeraria, desplazada de su ubicación original, de la familia Mallol (1622) y un bloque trabajado permanecen in situ. Así mismo siguen en su posición originaria las cuatro columnas con capitel del ábside mayor y las impostas de pilares y pilastras de la nave, una de ellas con decoración de damero/ajedrezado. El resto de piezas se hallan fuera del monasterio y dispersas. Un capitel recuperado durante las intervenciones de restauración está depositado actualmente en el Servei d'Atenció Museística de Girona (SAM). Otras nueve (dos capiteles y tres lápidas, además de dos fustes y dos bases de columna) se encuentran en la residencia de la familia Fina-Nouvilas de Castelló d'Empúries (Alt Empordà, Girona), herederos de los antiguos propietarios, que extrajeron del monasterio los capiteles (reutilizados en los ventanales de la construcción moderna en el lado sur del conjunto) y las lápidas (incrustadas hasta entonces en el muro sur de la iglesia), con anterioridad a la venta simbólica al Ayuntamiento de Rabós d'Empordà en 1994, amparándose -en su opiniónen el abandono y desprotección que sufría el monumento. En 1980 las piezas estaban aún en Sant Quirze, según tes- 
timonios gráficos. Desconocemos si esta familia tiene en su haber otros objetos y materiales procedentes del mismo lugar. A nuestro equipo sólo se le permitió ver y documentar dos capiteles y tres lápidas ${ }^{63}$. A este propósito es necesario hacer hincapié en que el monasterio fue declarado Monumento Histórico en el decreto del 3 de junio de 1931 (actual BCIN, núm. Reg. $175 \mathrm{MH}$ ) y consecuentemente, cualquier intervención y extracción de un elemento arquitectónico, escultórico o epigráfico, a partir de ese momento es ilegal. El material extraído de Sant Quirze lleva implícito un importante carácter histórico y artístico y, a nuestro parecer, es un hecho insólito que permanezca aún en manos privadas y que no haya sido recuperado y depositado en el patrimonio público, como corresponde.

Del conjunto de piezas en cuestión, las tres lápidas fueron dadas a conocer por Montsalvatje en $1896^{64}$, en tanto que Puig i Cadafalch, Falguera y Goday $(1909-1918)^{65}$, publicaron los capiteles ubicados en una fachada del edificio. Más recientemente, han sido recogidas en la obra monumental Catalunya Romànica ${ }^{66}$. El estudio más detallado es el que les ha dedicado I. Lorés, quien data el conjunto de capiteles entre los años 1170 y 118 o y considera que su ubicación originaria fue el claustro del monasterio ${ }^{67}$.

El primer paso dado por el equipo del proyecto ECLOC para el estudio de estos materiales escultóricos y epigráficos ha sido la generación de documentación fotogramétrica y su modelización en 3D con el objetivo de establecer un catálogo, lo más completo posible, tanto de la historiografía de la pieza hasta su análisis artístico e histórico, pasando por su catalogación y descripción. El Sr. Fina accedió a que pudiéramos efectuar el trabajo de digitalización de las piezas el mes de septiembre de 2016, trasladándolas para tal fin al garaje de la finca. En este trabajo presentamos una breve descripción de las mismas.

En el transcurso de 2016 se ha procedido al registro tridimensional de un total de 6 piezas (cinco en la residencia particular Fina-Nouvilas y un capitel depositado en el Servei d'Atenció als Museus en Girona), trabajo realizado por Raúl Balsera ${ }^{68}$. La obtención de modelos $3 \mathrm{D}$ se ha realizado a partir de técnicas fotogramétricas.

El material escultórico y epigráfico modelizado y ahora en proceso de análisis incluye las siguientes piezas:

1. Capitel figurativo decorado con parejas de leones rampantes. Piedra calcárea. Ubicación originaria desconocida, posiblemente el claustro. Localización secundaria: zona de cocina del refectorio, recuperado en una de las intervenciones arqueológicas en función de los proyectos de restauración. Localización actual: Servei d'Atenció al Museus, Generalitat de Catalunya (Girona), no de inventario SQC 97/1. Medidas: 36,2 x 27,1 x 26,5cm, 22,8cm diámetro de la base del capitel. Buen estado de conservación, con concreciones y partes ennegrecidas, completo.

2. Capitel figurativo decorado con cuatro personajes masculinos luchando contra dragones alados. Piedra calcárea. Ubicación originaria desconocida, posiblemente el claustro. Localización secundaria: ventana geminada neogótica, fachada sur del conjunto monástico. Localización actual: Residencia particular de R. Fina, Castelló d'Empúries (Alt Empordà, Girona). Medidas: 35 x 27,6 $\mathrm{x} 26,5 \mathrm{~cm}, 20 \mathrm{~cm}$ diámetro de la base del capitel. Buen estado de conservación, completo.

3. Capitel con decoración vegetal con hojas de acanto en la basey piñas como elemento principal en la parte superior. Conserva trazas de pintura de color rojizo y anaranjada que pueden ser de época moderna, así como restos blanquecinos por encima de concreción. Piedra calcárea. Ubicación originaria desconocida, posiblemente el claustro. Localización secundaria: ventana geminada neogótica, fachada sur del conjunto monástico. Localización actual: Residencia particular de R. Fina, Castelló d'Empúries (Alt Empordà, Girona). Medidas: 27 x 27 x $26 \mathrm{~cm}, 17 \mathrm{~cm}$ diámetro de la base del capitel. Buen estado de conservación, completo.

4. Lauda funeraria epigráfica, representación de las exequias del abad Berenguer de Vilatenim (1320), siguiendo el modelo habitual de la escena de funerales en la escultura gótica. El difunto aparece tumbado en primer término, en tanto que la comitiva fúnebre rodea el sepulcro depositando el cadáver en el vaso, bendiciéndolo e incensándolo. Mármol. Localización originaria: claustro, encastrada en el muro exterior sur de la iglesia, justo al oeste de la puerta. Localización actual: Residencia particular de R. Fina, Castelló d'Empúries (Alt Empordà, Girona). 53 x 90,5 × $6 \mathrm{~cm} ; 43$ × $77 \mathrm{~cm}$ escena central, 5 / $6 \mathrm{~cm}$ marco. Buen estado de conservación, completo, evidencias de desgastey ligera pérdida de material en las caras y cuerpos de los personajes. Grafitis en la los paneles del sarcófago del abad y trazas de pintura.

5. Relieve frontal con la representación de tres eclesiásticos en procesión, posiblemente un abad en el centro y dos ministros que marchan a ambos lados de éste, sosteniendo el gremial que le precede (fig. 27). Piedra calcárea. Localización originaria: claustro, encastada en el muro exterior sur de la iglesia. Localización actual: Residencia particular de R. Fina, Castelló d'Empúries (Alt Empordà, Girona). 46 x 67 x 12cm; 63 x 40cm escena central, $6 \mathrm{~cm}$ orla. Buen estado de conservación, completo. Evidencias de desgaste y ligera pérdida de material en los rostros de los eclesiásticos.

\footnotetext{
${ }_{63}$ I. Lorés apunta también la posible existencia de otros capiteles, a los cuales no tuvo acceso, como tampoco nosotros. Cree que hay al menos tres capiteles más, uno de ellos descrito sucintamente en B. AGUSTÍ, D. CODINA, D. DELHOUME, I. LORÉS y M. TEIXIDOR, "Sant Quirze de Colera entre els segles XII i XIV. D'edifici religiós a fortificació militar", Annals de l'Institut d'Estudis Empordanesos, 31 (1998), 111-131 (pp. 116-123). Así mismo, Lorés describe en dicho artículo dos fustes de columna y dos bases que formaban conjunto con los dos capiteles reubicados en los ventanales neogóticos del lado sur y que se hallaban en la residencia del Sr. Fina. No se nos mostraron.

${ }^{64}$ F. MONTSALVATJE, op. cit. (n. 26), pp. 74-78.

${ }^{65}$ J. PUIG I CADAFALCH, A. FALGUERA y J. GODAY, L'arquitectura romànica a Catalunya (Barcelona: Institut d'Estudis Catalans, 1909-1918), vol. III.2, pp. $731-856$.

${ }^{66}$ Catalunya Romànica IX, II, p. 757 (n. 27).

${ }^{67}$ B. AGUSTÍ, D. CODINA, D. DELHOUME, I. LORÉS y M. TEIXIDOR, op. cit. (n. 63).

${ }^{68} \mathrm{R}$. Balsera está realizando el proyecto de modelización $3 \mathrm{D}$ del Museu d'Arqueologia de Catalunya (MAC), el cual incluye objetos de las distintas sedes del MAC y de los museos de su red territorial (Arqueoxarxa).
} 


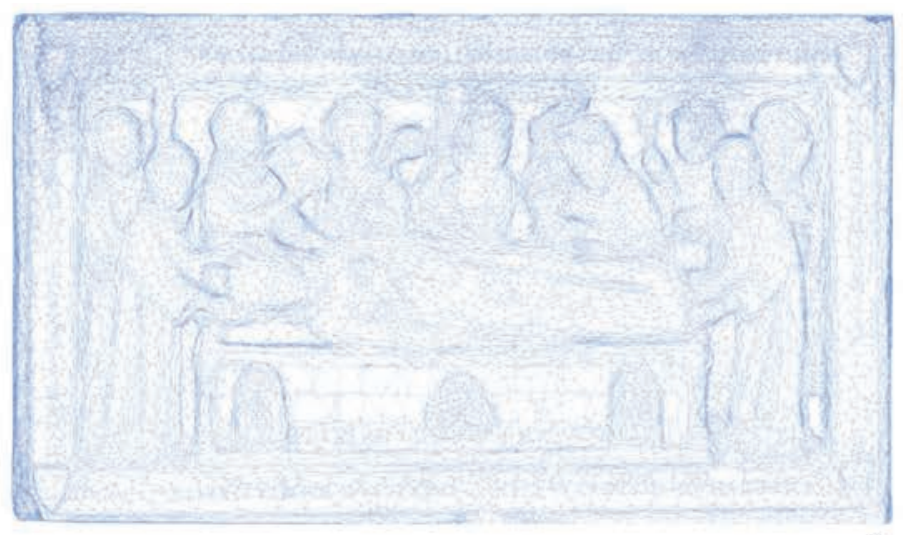

1

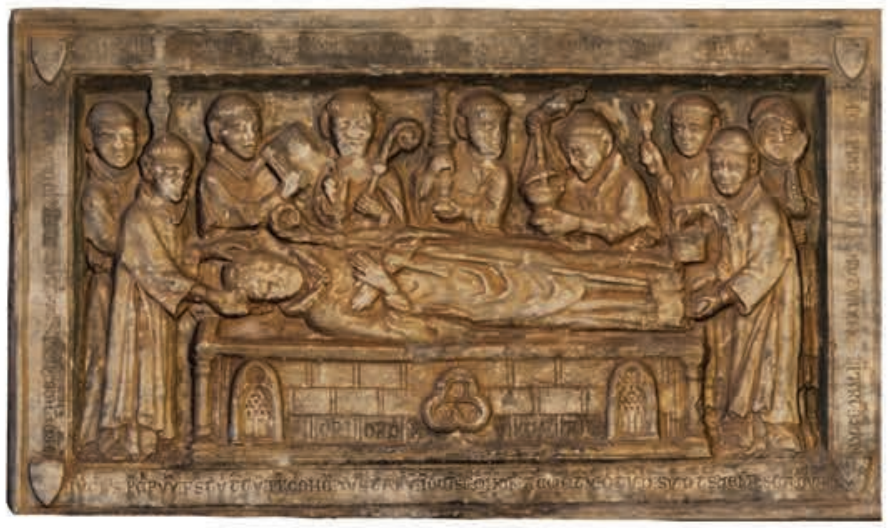

3
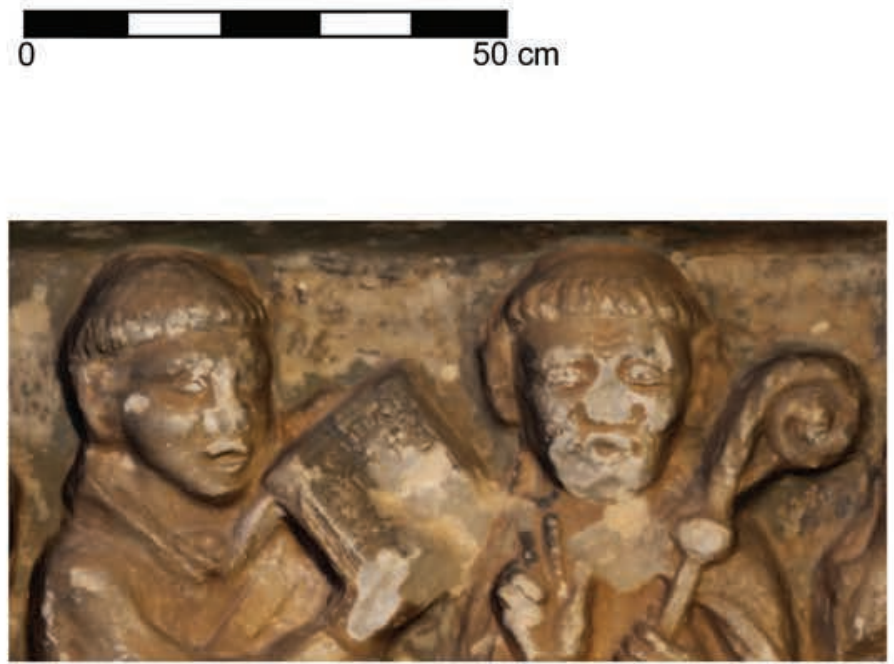

6

\section{0} $10 \mathrm{~cm}$
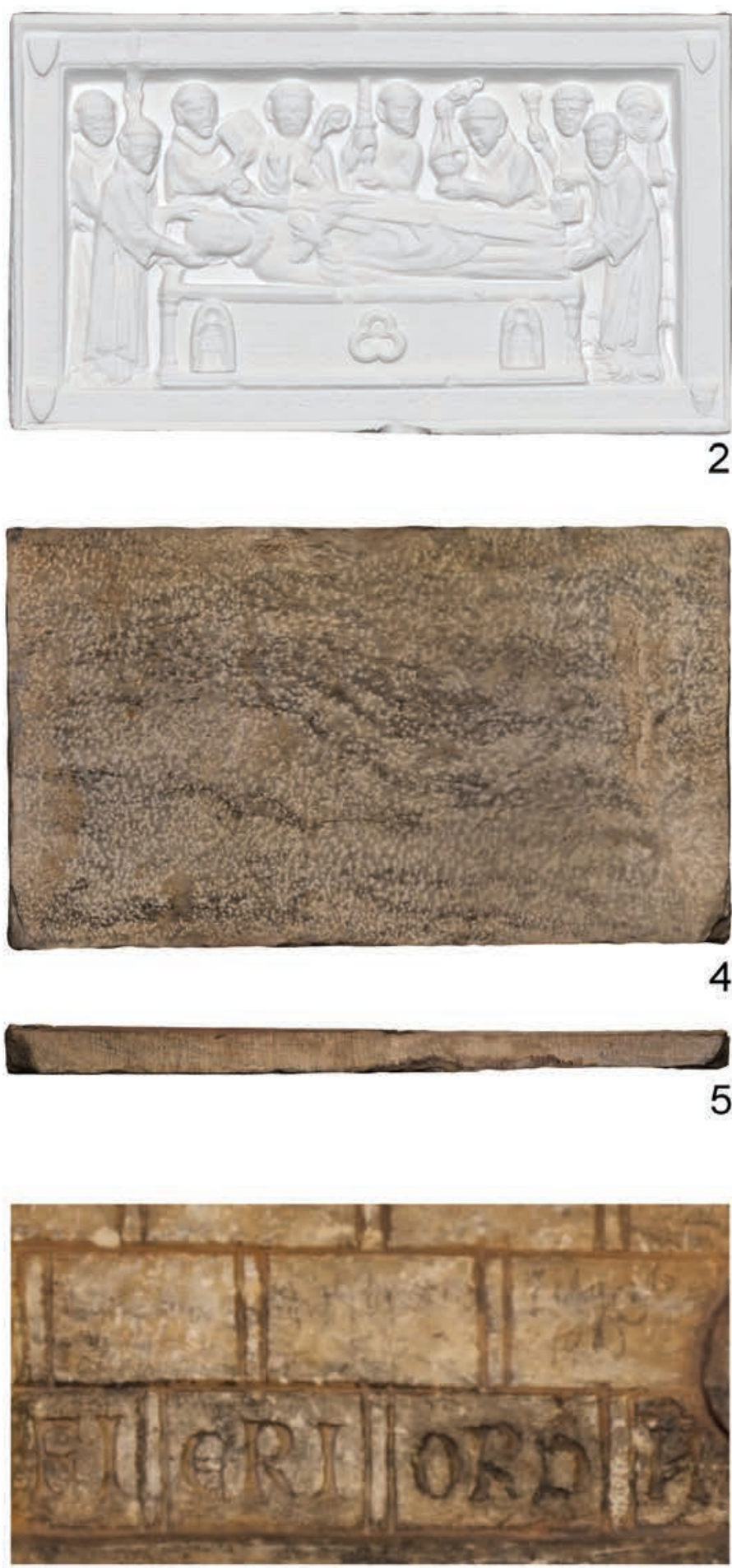

2

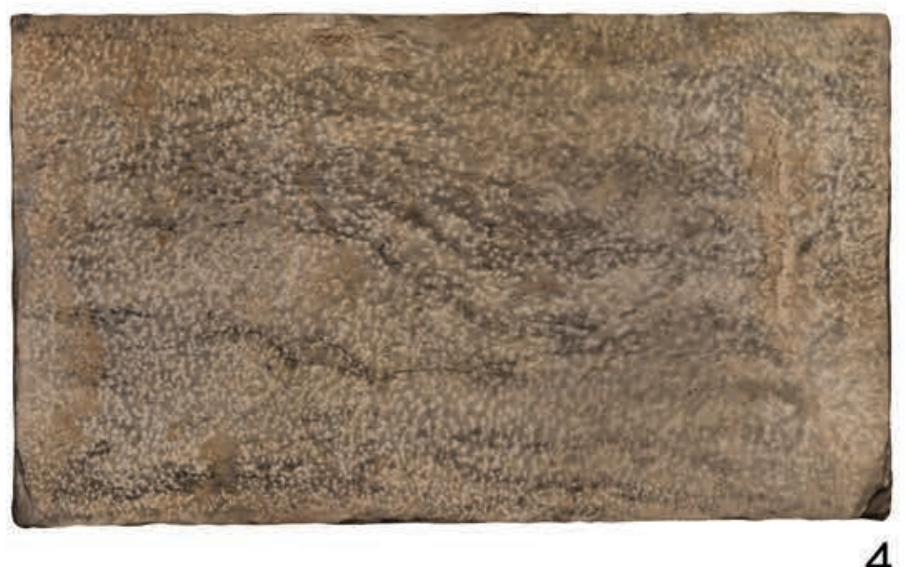

4

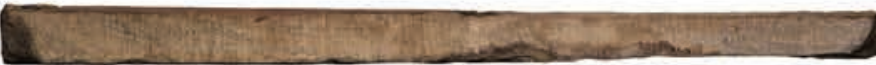

5

0

$10 \mathrm{~cm}$

Fig. 27. Lauda funeraria epigráfica de las exequias del abad Berenguer de Vilatenim (1320) $(53 \mathrm{~cm} \times 90,5 \mathrm{~cm} \times 6 \mathrm{~cm})$. Obtención del modelo 3D a partir de material fotogramétrico: 1, Nube de puntos. 2, Texturizado. 3, 4 y 5, Imagen final de la cara anterior, posterior e inferior. 6, Detalle donde se aprecia el estado de conservación. 7, Detalle del sarcófago, con epigrafía original y grafitis dentro de los casetones (ECLOC/R. Balsera).

6. Epitafio funerario del abat Ramon de Bianya (1296) con el texto distribuido en cinco líneas. Piedra calcárea. Localización originaria: claustro, encastada en el muro exterior sur de la iglesia. Localización actual: Residencia particular de R. Fina, Castelló d'Empúries (Alt Empordà, Girona). Medidas: 39 x 63,5 X 10,5cm (irregular). Buen estado de conservación, completo. La zona de la inscripción presenta una coloración más oscura que el perímetro.

\section{A MODO DE CONCLUSION}

Todas las acciones que estamos ejecutando en Sant Quirze de Colera, tal como se ha visto en las páginas precedentes, están encaminadas a un estudio completo, desde todos los puntos de vista. Y también se ha dicho que éste análisis sólo puede ser efectuado si se dispone de un material puesto al día, es decir una documentación que proporcione a los investigadores y a la comunidad científica un instrumento de 
trabajo, y, a su vez, quede como un legado para las futuras generaciones y, cómo no, como un utensilio que, adaptado, sirva para la difusión patrimonial.

El análisis topográfico, fotogramétrico y de modelización $3 \mathrm{D}$, ejecutado con la tecnología más puntera, genera una masa de información geométrica y de altísima calidad que permite trabajar en condiciones de rigor y excelencia. Los resultados están en la base de todo el estudio cronoestratigráfico, es decir constructivo, arquitectónico y litúrgico, en definitiva histórico de los múltiples elementos que componen el conjunto monástico y la iglesia parroquial de Sant Quirze de Colera.

Las intervenciones arqueológicas, de consolidación y restauración, además de la musealización, llevadas a cabo desde mediados de los años noventa del siglo XX hasta inicios del siglo XXI, nos obligan a implementar métodos de registro adecuados y adaptados a la propia idiosincrasia de las estructuras conservadas. Por otro lado, todas las fuentes textuales y los hechos constructivos, arquitectónicos y litúrgicos, además de las patologías y dinámicas estructurales y geológicas que se han sucedido en el monumento han de ser gestionados y puestos en relación. Por ello, y para llegar a entender cuál es la secuencia crono-estratigráfica de todas las estructuras y su interrelación, hemos construido una estructura de datos, un sistema de información espacio-temporal, que ordena de forma lógica todos los acontecimientos relacionados entre sí. Los desafíos que plantea la suma de todos estos factores son de gran interés, tanto a nivel metodológico, como de resultados históricos, porque el objetivo no es posibilitar una crónica de los hechos sucedidos en el conjunto monástico, sino establecer una aproximación interdisciplinar donde todos los elementos estén interrelacionados y contextualizados posibilitando así una comprensión y explicación fehacientes del proceso constructivo-arquitectónico. En conclusión, la fundación, construcción, uso y abandono del yacimiento, teniendo en cuenta su dilatada cronología, desde los siglos VIII-IX hasta el siglo XVI, y su posterior uso como masía para la explotación agrícola y ganadera que supuso, como se ha visto, un gravísimo deterioro de los elementos y espacios arquitectónicos y litúrgicos.

El análisis arquitectónico del edificio se ha centrado, por el momento, en la iglesia abacial, la posible existencia de una primera iglesia enmascarada por las refacciones posteriores y en el claustro y las estructuras constructivas en su sector este. No se trata de una cuestión fácil porque tras las excavaciones arqueológicas llevadas a cabo tanto en la iglesia, como en el claustro y el refectorio se procedió a una importante acción musealizadora que permitiera la visita, es decir se ha organizado el paso de visitantes por medio de pasarelas y pavimentos que asentados directamente sobre los restos arqueológicos y arquitectónicos impiden hacer determinadas comprobaciones. En cualquier caso el problema de la existencia de una primera iglesia se focaliza en los restos todavía visibles en el ábside sur. La cimentación se conserva en tres hiladas en opus spicatum asentadas directamente sobre la roca natural y dibuja un perímetro, cuasi semicircular de 1,30m de ancho, alcanzando incluso en algunos puntos los 1,6om. Si esta estructura tiene algo que ver con el texto del año 844 o con la iglesia del acta de consagración del 935, es algo que todavía es necesario trabajar en profundidad. Los restos de este hemiciclo son del mismo momento constructivo que las habitaciones al este del claus- tro, que responden -muy probablemente- a dependencias u oficinas comunitarias y a la sala capitular, ubicación, por otra parte, habitual en los monasterios benedictinos. Este conjunto de tres espacios yuxtapuestos forman una unidad constructiva, arquitectónica y funcional. Su análisis no es fácil porque están alterados y degradados por los diversos usos a los que han estado sometidos. Por otro lado, una de las conclusiones importantes es que el acceso al cenobio, no se hacía por el lado este, tal como plantea la musealización. Este sector estuvo cerrado por el exterior y abierto al claustro. En cualquier caso, el análisis -de aquí en adelante-plantea retos interesantes en lo que a la topografía del claustro respecta.

Una cuestión importante es la de si somos capaces de identificar la iglesia con triple advocación del acta de consagración del año 935. Sabemos que existe una reforma y reconstrucción que acontece en un segundo momento porque utiliza la cimentación del ábside sur, al que se le añaden el ábside central o mayor y el norte, configurando una cabecera triabsidada, hoy desfigurada por la capilla abierta entre el ábside mayor y el meridional en época bajo medieval. Esta nueva cabecera tiene una singularidad puesto que la absidiola septentrional está cosida al cuerpo central del transepto y al ábside mayor por medio de un muro, a nivel de cimentación y en sentido norte-sur, que debió tener las funciones de tirante. Sin embargo, nada indica que ésta sea la iglesia reformada por el abad Manuel, la del 935, tal como se ha argumentado. La triple advocación bien puede referirse a altares o capillas y no a una cabecera de triple ábside. Ésta corresponde a la obra románica, obra que bien pude ser el resultado de dos fases constructivas. El acta de consagración del año 1123 es quizá el resultado final de las obras de remodelación emprendidas con anterioridad y, a nuestro parecer, no es el instrumento fehaciente para datar la arquitectura de la iglesia que se conserva hoy en día. Tanto la arquitectura como los elementos estructurales, aparejo, morfología de las ventanas y decoración interior y exterior de la cabecera, confirman que estamos ante un edificio de la primera mitad del siglo XI.

Centrándonos ahora en la iglesia románica, hemos puntualizado las dos claras fases de su proceso constructivo románico, desde el primer taller que planteó un monumental edificio, hasta la alteración de este primer proyecto por un segundo taller que bien no pudo o no supo gestionar un espacio tan grandey tan elevado, sin prever un buen sistema de responsiones para las naves laterales que sostenían la central con una marcada proyección en altura. Este fue el motivo para el derrumbe de la sección norte de la fábrica y por el que la iglesia siempre ha tenido problemas de estabilidad hasta nuestros días. El proyecto arquitectónico fue corregido, quizá, sobrealzando las naves laterales y rebajando la altura de los arcos formeros del intercolumnio del primer tramo de la nave central, desde el crucero. Este rebaje de los arcos permitió construir dos habitaciones en altura. No se trata de tribunas porque no tienen ningún sentido litúrgico, son espacios ciegos sin acceso ni ventanas abiertas sobre el transepto o la nave. Lo que sí tienen es una clara función arquitectónica de resistencia y articulación entre las naves y el transepto.

Tocante a las instalaciones litúrgicas, Sant Quirze de Colera es un ejemplo modélico para entender la colocación e instalación del coro monástico en tiempos del románico, sobreelevado en una plataforma que ocupaba la capilla mayor. La constatación de al menos dos fases completamente diferentes en su evolución diacrónica permite diferenciar 
dos estructuras corales dispares que determinan dos fases también distintas en lo que es la organización litúrgica. En relación al ábside central y al centro del transepto, toda una serie de indicios, confirman la existencia de una plataforma coral, un primer coro, coetáneo a la iglesia románica. La presencia de improntas a media altura del perímetro del muro interno del ábside central y la conservación de una pequeña cubeta litúrgica en el vano sur del hemiciclo, sitúan el suelo original del ábside a una altura superior de dos metros por encima del nivel actual de circulación. Las estructuras en piedra y recubiertas de mortero dispuestas en el transepto, además de los tramos de escaleras a lado y lado del frente del ábside central, son los soportes arquitectónicos de la plataforma coral sobreelevada que ocupaba el ábside central y la zona medial del transepto. En el ábside, la sobreelevación era de obra, en el resto, de madera. Los tramos de escaleras, en el transepto y a ambos lados del ábside daban acceso a la parte baja de la estructura en madera, el sotocoro. Probablemente existió un acceso central en el eje, que a día de hoy se nos escapa.
El espacio coral se vio alterado, quizás desplazado, tal vez duplicado, con motivo de las reformas benedictinas, institucionales y litúrgicas, de los siglos XV y XVI, que llevaron a una generalizada ubicación de un coro a los pies, bien conectado con las nuevas celdas de los monjes, aun manteniéndose las antiguas estructuras corales en la cabecera. En Sant Quirze de Colera, la sillería del coro de los monjes se reubicó en la nave central, construyendo así un trascoro que dejaba libres los tramos occidentales. Este nuevo emplazamiento se certifica por las improntas, todavía hoy visibles en el pavimento de la nave central tanto en el norte como en el sur y el límite oeste, y al rebaje de los pilares de sección cruciforme que miran sobre la nave. La ubicación y dimensiones de este trascoro es un hecho normal y frecuente en iglesias abaciales de esta cronología.

En conclusión, el trabajo iniciado en el marco del proyecto ECLOC, está proporcionando una serie de elementos que facilitarán una lectura e interpretación nuevas del conjunto monástico de Sant Quirze de Colera. Aquí hemos querido dar a conocer algunos de los resultados preliminares sobre los que seguimos trabajando en profundidad. 